Supporting Information

\title{
Gold-Catalyzed Efficient Preparation of Linear $\alpha$-lodoenone from Propargylic acetates
}

\author{
Meng Yu, Guozhu Zhang, and Liming Zhang* \\ Department of Chemistry/216, University of Nevada, Reno \\ 1664 North Virginia Street, Reno, Nevada 89557
}


General. Ethyl acetate (ACS grade), hexanes (ACS grade) and diethyl ether (ACS grade) were purchased from Fisher Scientific and used without further purification. Anhydrous Acetone (HPLC grade) was purchased from Acros Organics. Anhydrous tetrahydrofuran in Pure-Pac ${ }^{\mathrm{TM}}$ from Aldrich was used directly without further purification. Nbromosuccinimide was purchased from Acros Organics. N-lodosuccinimide was purchased from Alfa Aesar. Commercially available reagents were used without further purification. Reactions were monitored by thin layer chromatography(TLC) using silicycle precoated silica gel plates. Flash column chromatography was performed over silicycle silica gel (230-400 mesh). ${ }^{1} \mathrm{H}$ NMR and ${ }^{13} \mathrm{C}$ NMR spectra were recorded on a Varian 500 $\mathrm{MHz}$ Unity plus spectrometer and a Varian $400 \mathrm{MHz}$ spectrometer using residue solvent peaks as internal standards. Infrared spectra were recorded with a Perkin Elmer FT-IR spectrum 2000 spectrometer and are reported in reciprocal centimeter $\left(\mathrm{cm}^{-1}\right)$. Mass spectra were recorded with Waters micromass ZQ detector using electron spray method.

\section{General procedure A: Preparation of propargylic acetates}

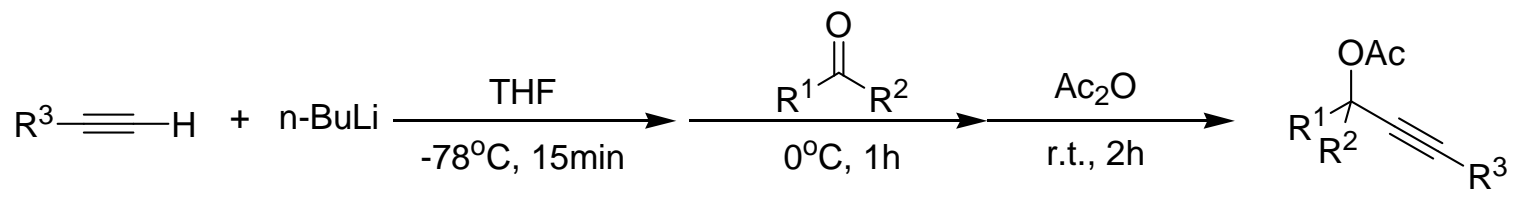

To a solution of alkyne $(11 \mathrm{mmol})$ in anhydrous THF $(42 \mathrm{~mL})$ at $-78^{\circ} \mathrm{C}$ under $\mathrm{N}_{2}$ was added $n$-BuLi (2.5 M solution in hexanes, $4.2 \mathrm{~mL}, 10.5 \mathrm{mmol})$. The reaction was stirred at the same temperature for $15 \mathrm{~min}$ before the addition of ketone/aldehyde (10 $\mathrm{mmol})$. The resulting mixture was allowed to warm to $0^{\circ} \mathrm{C}$ gradually and stirred for an additional hour. Upon the addition of acetate anhydrous $(2.4 \mathrm{~mL}, 25 \mathrm{mmol})$, the reaction mixture was warmed to room temperature and stirred for $2 \mathrm{~h}$ before quenched with aqueous $\mathrm{NaHCO}_{3}$. The mixture was extracted with $\mathrm{Et}_{2} \mathrm{O}(3 \times 30 \mathrm{~mL})$, and the combined organic phases were washed with water and brine, dried with anhydrous $\mathrm{MgSO}_{4}$, and filtered. The filtrate was concentrated, and the residue was purified through silica gel flash column chromatography (hexanes/ethyl acetate $=20 / 1$ ) to yield the desired acetate. 


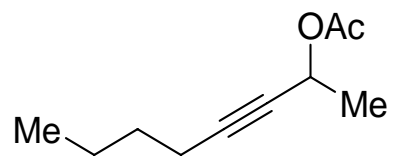

1

Compound 1 was prepared in $86 \%$ yield according to the general procedure A. ${ }^{1} \mathrm{H}$ NMR $\left(400 \mathrm{MHz}, \mathrm{CDCl}_{3}\right.$ ) $\delta 5.44$ (qt, $\left.1 \mathrm{H}, J=6.8,2.0 \mathrm{~Hz}\right), 2.20$ (td, $2 \mathrm{H}, J=7.0,2.0 \mathrm{~Hz}$ ), $2.06(\mathrm{~s}, 3 \mathrm{H}), 1.53-1.34(\mathrm{~m}, 7 \mathrm{H}), 0.91(\mathrm{t}, 3 \mathrm{H}, J=7.2 \mathrm{~Hz}) ;{ }^{13} \mathrm{C}$ NMR $\left(100 \mathrm{MHz}, \mathrm{CDCl}_{3}\right) \delta$ 170.0, 85.6, 78.6, 60.9, 30.6, 21.9, 21.8, 21.2, 18.4, 13.6; IR (neat): 2989, 2960, 2937, $2874,2249,1744,1467,1453,1371 ; M S\left(E^{+}\right)$Calculated for $\left[\mathrm{C}_{10} \mathrm{H}_{16} \mathrm{NaO}_{2}\right]^{+}: 191.1$; Found: 191.0 .

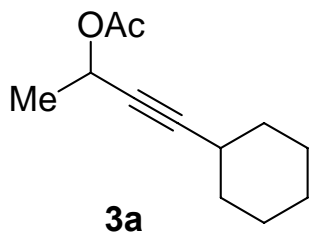

Compound 3a was prepared in $83 \%$ yield according to the general procedure $A$. ${ }^{1} \mathrm{H}$ NMR $\left(500 \mathrm{MHz}, \mathrm{CDCl}_{3}\right) \delta 5.47$ (qt, $\left.1 \mathrm{H}, J=6.5,2.0 \mathrm{~Hz}\right), 2.40-2.36(\mathrm{~m}, 1 \mathrm{H}), 2.07$ (s, $3 \mathrm{H}), 1.79$ - $1.67(\mathrm{~m}, 4 \mathrm{H}), 1.50$ - $1.39(\mathrm{~m}, 7 \mathrm{H}), 1.32$ - $1.27(\mathrm{~m}, 2 \mathrm{H}) ;{ }^{13} \mathrm{C}$ NMR (125 MHz, $\left.\mathrm{CDCl}_{3}\right) \delta 170.0,89.5,78.5,60.9,32.4,28.9,25.8,24.8,21.9,21.2 ;$ IR (neat):2988, 2933, 2856, 2244, 1741, 1592, 1450, 1317, 1340, 1309, 1224, 1170, 1592, 1450; MS (ES $\left.{ }^{+}\right)$ Calculated for $\left[\mathrm{C}_{12} \mathrm{H}_{18} \mathrm{NaO}_{2}\right]^{+}:$217.3; Found: 217.2 .

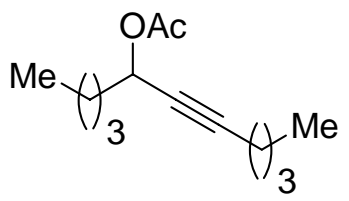

$3 b$

Compound $\mathbf{3 b}$ was prepared in $80 \%$ yield according to the general procedure $A$. ${ }^{1} \mathrm{H}$ NMR $\left(500 \mathrm{MHz}, \mathrm{CDCl}_{3}\right) \delta 5.35(\mathrm{t}, 1 \mathrm{H}, \mathrm{J}=6.5 \mathrm{~Hz}), 2.21(\mathrm{td}, 2 \mathrm{H}, \mathrm{J}=7.0,1.7 \mathrm{~Hz}), 2.07$ (s, 3H), 1.77 - $1.69(\mathrm{~m}, 2 \mathrm{H}), 1.49$ (Quintet, 2H, J = 7.2 Hz), 1.43 - $1.31(\mathrm{~m}, 6 \mathrm{H}), 0.93$ $0.89(\mathrm{~m}, 6 \mathrm{H}), ;{ }^{13} \mathrm{C}$ NMR $\left(125 \mathrm{MHz}, \mathrm{CDCl}_{3}\right) \delta$ 170.1, 86.1, 77.6, 64.6, 34.8, 30.6, 27.2, 22.2, 21.9, 21.2, 18.4, 13.9, 13.6; IR (neat):2959, 2935, 2871, 2864, 2242, 1743, 1468, 
1433, 1371, 1351, 1234, 1161, 1108, 1019, 959; $\mathrm{MS}\left(\mathrm{ES}^{+}\right)$Calculated for $\left[\mathrm{C}_{13} \mathrm{H}_{22} \mathrm{NaO}_{2}\right]^{+}$: 233.3; Found: 233.3.

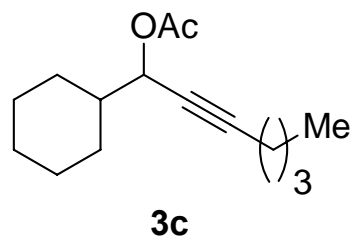

Compound $3 \mathrm{c}$ was prepared in $84 \%$ yield according to the general procedure $A$. ${ }^{1} \mathrm{H}$ NMR $\left(500 \mathrm{MHz}, \mathrm{CDCl}_{3}\right) \delta 5.20(\mathrm{~d}, 1 \mathrm{H}, J=6.0 \mathrm{~Hz}), 2.21(\mathrm{t}, 2 \mathrm{H}, J=7.0 \mathrm{~Hz}), 2.07$ (s, 3H), 1.84 - $1.58(\mathrm{~m}, 5 \mathrm{H}), 1.49$ (Quintet, 2H, $J=7.2 \mathrm{~Hz}$ ), 1.39 (Sextet, $2 \mathrm{H}, J=7.2 \mathrm{~Hz}$ ), $1.27-1.03(\mathrm{~m}, 6 \mathrm{H}), 0.90(\mathrm{t}, 3 \mathrm{H}, J=7.2 \mathrm{~Hz}) ;{ }^{13} \mathrm{C}$ NMR $\left(125 \mathrm{MHz}, \mathrm{CDCl}_{3}\right) \delta 170.2,86.8$, $76.4,68.8,42.0,30.6,28.6,28.0,26.2,25.8,25.7,21.9,21.1,18.4,13.6$; IR (neat):2960, 2931, 2856, 2239, 1742, 1593, 1452, 1432, 1370, 1231, 1119, 1018, 977; MS (ES $\left.{ }^{+}\right)$ Calculated for $\left[\mathrm{C}_{15} \mathrm{H}_{24} \mathrm{NaO}_{2}\right]^{+}:$259.4; Found: 259.2 .

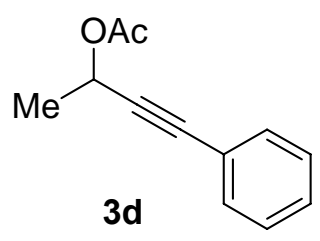

Compound $\mathbf{3 d}$ was prepared in $86 \%$ yield according to the general procedure $A$. ${ }^{1} \mathrm{H}$ NMR $\left(400 \mathrm{MHz}, \mathrm{CDCl}_{3}\right) \delta 7.45-7.43(\mathrm{~m}, 2 \mathrm{H}), 7.33-7.27(\mathrm{~m}, 3 \mathrm{H}), 5.67(\mathrm{q}, 1 \mathrm{H}, \mathrm{J}=6.6$ $\mathrm{Hz}), 2.11(\mathrm{~s}, 3 \mathrm{H}), 1.58(\mathrm{~d}, 3 \mathrm{H}, J=6.6 \mathrm{~Hz}) ;{ }^{13} \mathrm{C} \mathrm{NMR}\left(100 \mathrm{MHz}, \mathrm{CDCl}_{3}\right) \delta 169.9,131.8$, 128.6, 128.2, 122.2, 87.4, 84.5, 60.8, 21.5, 21.1; IR (neat): 3058, 2990, 2939, 2247, $1743,1599,1491,1444,1372$; $M S\left(E S^{+}\right)$Calculated for $\left[\mathrm{C}_{12} \mathrm{H}_{12} \mathrm{NaO}_{2}\right]^{+}:$211.1; Found: 210.9 .

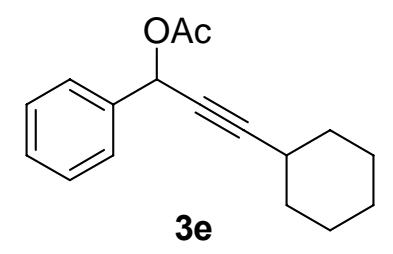

Compound $3 \mathrm{e}$ was prepared in $94 \%$ yield according to the general procedure $\mathrm{A}$. ${ }^{1} \mathrm{H}$ NMR $\left(400 \mathrm{MHz}, \mathrm{CDCl}_{3}\right) \delta 7.55-7.51(\mathrm{~m}, 2 \mathrm{H}), 7.39-7.31(\mathrm{~m}, 3 \mathrm{H}), 6.49(\mathrm{~d}, 1 \mathrm{H}, J=2.0$ 
$\mathrm{Hz}), 2.49-2.44(\mathrm{~m}, 1 \mathrm{H}), 2.09(\mathrm{~s}, 3 \mathrm{H}), 1.82-1.79(\mathrm{~m}, 2 \mathrm{H}), 1.73-1.66(\mathrm{~m}, 2 \mathrm{H}), 1.54-1.43$ (m, 3H), 1.36-1.26 (m, 3H); ${ }^{13} \mathrm{C}$ NMR (100 MHz, $\left.\mathrm{CDCl}_{3}\right) \delta 169.9,137.8,128.7,128.5$, 127.7, 92.3, 76.6, 66.0, 32.37, 32.35, 29.1, 25.8, 24.8, 21.2; IR (neat): 3090, 3066, 3035, 2932, 2855, 2236, 1742, 1604, 1588, 1495, 1450, 1369; MS $\left(\mathrm{ES}^{+}\right)$Calculated for $\left[\mathrm{C}_{17} \mathrm{H}_{20} \mathrm{NaO}_{2}\right]^{+}: 279.1$; Found: 279.1 .

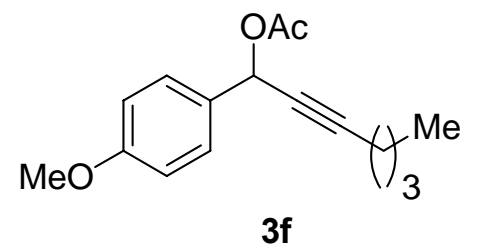

Compound $\mathbf{3 f}$ was prepared in $87 \%$ yield according to the general procedure $\mathrm{A}$. ${ }^{1} \mathrm{H} \mathrm{NMR}\left(500 \mathrm{MHz}, \mathrm{CDCl}_{3}\right) \delta 7.46(\mathrm{~d}, 2 \mathrm{H}, J=8.5 \mathrm{~Hz}), 6.89(\mathrm{~d}, 2 \mathrm{H}, J=8.5 \mathrm{~Hz}), 6.42(\mathrm{~s}$, $1 \mathrm{H}$ ), $3.81(\mathrm{~s}, 3 \mathrm{H}), 2.27(\mathrm{t}, 2 \mathrm{H}, J=7.0 \mathrm{~Hz}$ ), $2.07(\mathrm{~s}, 3 \mathrm{H}), 1.52$ (Quintet, $2 \mathrm{H}, J=7.2 \mathrm{~Hz}$ ), 1.41 (Sextet, $2 \mathrm{H}, J=7.2 \mathrm{~Hz}$ ), 0.91 (t, $3 \mathrm{H}, J=7.2 \mathrm{~Hz}) ;{ }^{13} \mathrm{C} \mathrm{NMR}\left(125 \mathrm{MHz}, \mathrm{CDCl}_{3}\right) \delta$ 170.0, 159.9, 129.9, 129.3, 113.8, 88.1, 76.8, 65.8, 55.3, 30.5, 21.9, 21.2, 18.5, 13.6; IR (neat): 3072, 3037, 3003, 2959, 2935, 2873, 2838, 2292, 2234, 1741, 1611, 1587, 1514, $1465,1443,1428,1369,1343,1305,1279,1251,1229,1175,1144,1110,1034,1015$, 952, 909, 832; MS (ES $)$ Calculated for $\left[\mathrm{C}_{16} \mathrm{H}_{20} \mathrm{NaO}_{3}\right]^{+}:$283.3; Found: 283.2.

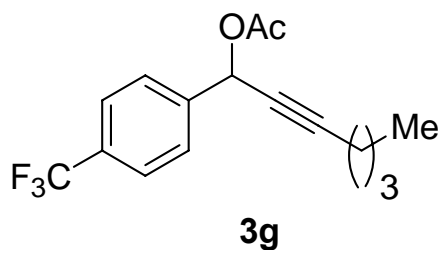

Compound 3gwas prepared in $85 \%$ yield according to the general procedure $\mathrm{A}$. ${ }^{1} \mathrm{H} \mathrm{NMR}\left(400 \mathrm{MHz}, \mathrm{CDCl}_{3}\right) \delta 7.63(\mathrm{~s}, 1 \mathrm{H}), 6.48(\mathrm{t}, 1 \mathrm{H}, J=2.0 \mathrm{~Hz}), 2.27(\mathrm{td}, 2 \mathrm{H}, J=7.2$, $2.4 \mathrm{~Hz}$ ), 2.11 (s, 3H), 1.52 (Quintet, $2 \mathrm{H}, J=7,2 \mathrm{~Hz}$ ), 1.40 (Sextet, $2 \mathrm{H}, J=7.2 \mathrm{~Hz}$ ), 0.91 (t, $3 \mathrm{H}, J=7.2 \mathrm{~Hz}$ ); ${ }^{13} \mathrm{C}$ NMR $\left(100 \mathrm{MHz}, \mathrm{CDCl}_{3}\right) \delta 169.7,141.5,130.8\left(\mathrm{q}, J_{\mathrm{C}-\mathrm{F}}=32 \mathrm{~Hz}\right.$ ), $127.9,125,6\left(q, J_{C-F}=3.7 \mathrm{~Hz}\right), 123.9\left(q, J_{C-F}=270.0 \mathrm{~Hz}\right), 89.2,76.0,65.3,30.4,21.9$, 21.0, 18.5, 13.5; IR (neat):3067, 2962, 2935, 2876, 2295, 2236, 1928, 1746, 1622, 1590, $1468,1422,1371,1327,1227,1168,1129,1109,1068,1018,959,922,850,836$; MS $\left(\mathrm{ES}^{+}\right)$Calculated for $\left[\mathrm{C}_{16} \mathrm{H}_{17} \mathrm{NaO}_{2}\right]^{+}$: 321.3; Found: 321.2. 


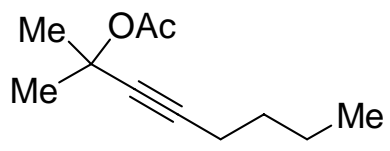

$5 a$

Compound $\mathbf{5 a}$ was prepared in $74 \%$ yield according to the general procedure C. ${ }^{1} \mathrm{H}$ NMR (500MHz, $\left.\mathrm{CDCl}_{3}\right) \delta 2.20(\mathrm{t}, 2 \mathrm{H}, J=7.0), 2.01(\mathrm{~s}, 3 \mathrm{H}), 1.64(\mathrm{~s}, 6 \mathrm{H}), 1.48(\mathrm{p}, 2 \mathrm{H}$, $J=7.6 \mathrm{~Hz}$ ), 1.39 (sextet, $2 \mathrm{H}, J=7.6 \mathrm{~Hz}), 0.90$ (t, 3H, $J=7.6) ;{ }^{13} \mathrm{C} \mathrm{NMR}(125 \mathrm{MHz}$, $\left.\mathrm{CDCl}_{3}\right) \delta 169.4,84.6,81.3,72.6,30.6,29.3,22.1,21.9,18.4,13.6$; IR (neat): 2987, 2960, 2936, 2875, 2245, 1747, 1586, 1468, 1434, 1368, 1329, 1266, 1245, 1196, 1016, 953 , 822; $\mathrm{MS}\left(\mathrm{ES}^{+}\right)$Calculated for $\left[\mathrm{C}_{11} \mathrm{H}_{18} \mathrm{NaO}_{2}\right]^{+}$: 205.1; Found: 205.1.

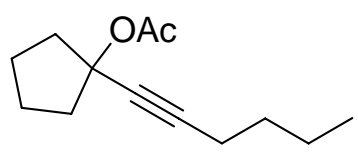

$5 b$

Compound $\mathbf{5 b}$ was prepared in $70 \%$ yield according to the general procedure $\mathrm{C}$. ${ }^{1} \mathrm{H}$ NMR $\left(400 \mathrm{MHz}, \mathrm{CDCl}_{3}\right) \delta 2.22-2.15(\mathrm{~m}, 4 \mathrm{H}), 2.12-2.04(\mathrm{~m}, 2 \mathrm{H}), 2.02(\mathrm{~s}, 3 \mathrm{H}), 1.74-$ $1.70(\mathrm{~m}, 4 \mathrm{H}), 1.50-1.44(\mathrm{~m}, 2 \mathrm{H}), 1.43-1.35(\mathrm{~m}, 2 \mathrm{H}), 0.90(\mathrm{t}, 3 \mathrm{H}, J=7.6 \mathrm{~Hz}) ;{ }^{13} \mathrm{C} \mathrm{NMR}$ $\left(100 \mathrm{MHz}_{\mathrm{CDCl}}\right) \delta 169.7,85.3,81.0,80.5,40.5,30.7,23.2,21.9,18.5,13.6$; IR (neat): 2960, 2933, 2875, 2246, 1746, 1593, 1453, 1435, 1367, 1334, 1241, 1124, 1016, 970; MS (ES ${ }^{+}$) Calculated for $\left[\mathrm{C}_{13} \mathrm{H}_{20} \mathrm{NaO}_{2}\right]^{+}:$231.1; Found: 231.1.

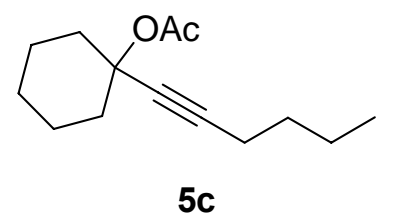

Compound 5c was prepared in $84 \%$ yield according to the general procedure C. ${ }^{1} \mathrm{H}$ NMR $\left(400 \mathrm{MHz}, \mathrm{CDCl}_{3}\right) \delta 2.254(\mathrm{t}, 2 \mathrm{H}, J=7.2 \mathrm{~Hz}), 2.11-2.06(\mathrm{~m}, 2 \mathrm{H}), 2.03(\mathrm{~s}, 3 \mathrm{H})$, 1.84-1.77 (m, 2H), 1.63-1.29 (m, 10H), $0.91(\mathrm{t}, 3 \mathrm{H}, J=7.2 \mathrm{~Hz}) ;{ }^{13} \mathrm{C}$ NMR $(100 \mathrm{MHz}$, $\left.\mathrm{CDCl}_{3}\right) \delta 169.3,86.8,80.0,76.1,37.4,30.8,25.3,22.7,22.1,21.9,18.5,13.6$; IR (neat): 2936, 2861, 2244, 1746, 1600, 1447, 1431, 1367, 1301, 1264, 1230, 1184, 1131, 1034, 1020, 965; MS (ES $\left.{ }^{+}\right)$Calculated for $\left[\mathrm{C}_{14} \mathrm{H}_{22} \mathrm{NaO}_{2}\right]^{+}:$245.2; Found: 245.1. 


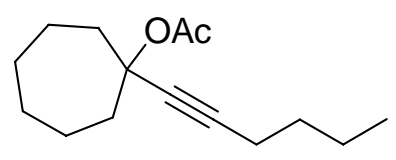

5d

Compound $\mathbf{5} \mathbf{d}$ was prepared in $70 \%$ yield according to the general procedure C. ${ }^{1} \mathrm{H}$ NMR $\left(400 \mathrm{MHz}, \mathrm{CDCl}_{3}\right) \delta$ 2.24-2.17 (m, 4H), 2.06-2.04 (m, 2H), $2.01(\mathrm{~s}, 3 \mathrm{H}), 1.57-$ $1.37(\mathrm{~m}, 12 \mathrm{H}), 0.90(\mathrm{t}, 3 \mathrm{H}, \mathrm{J}=7.2 \mathrm{~Hz}) ;{ }^{13} \mathrm{C}$ NMR $\left(100 \mathrm{MHz}, \mathrm{CDCl}_{3}\right) \delta$ 169.4, 86.0, 81, 2, 79.5, 40.5, 30.7, 28.2, 22.2, 21.9, 18.5, 13.6; IR (neat): 2936, 2861, 2244, 1746, 1600, 1447, 1431, 1367, 1301, 1264, 1230, 1184, 1131, 1034, 1020, 965; MS (ES ${ }^{+}$) Calculated for $\left[\mathrm{C}_{15} \mathrm{H}_{24} \mathrm{NaO}_{2}\right]^{+}:$257.2; Found: 259.2.

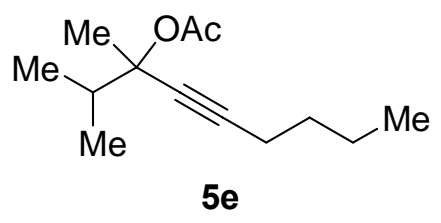

Compound 5 e was prepared in $80 \%$ yield according to the general procedure $\mathrm{C}$. ${ }^{1} \mathrm{H}$ NMR (400 MHz, CDCl $\left.{ }_{3}\right) \delta 2.23(\mathrm{t}, 2 \mathrm{H}, J=7.2 \mathrm{~Hz}$ ), 2.16 (heptet, $1 \mathrm{H}, J=6.6 \mathrm{~Hz}$ ), 2.01 $(\mathrm{s}, 3 \mathrm{H}), 1.61(\mathrm{~s}, 3 \mathrm{H}), 1.53-1.43(\mathrm{~m}, 2 \mathrm{H}), 1.42-1.37(\mathrm{~m}, 2 \mathrm{H}), 1.01(\mathrm{~d}, 3 \mathrm{H}, J=6.6 \mathrm{~Hz})$, $0.97(\mathrm{~d}, 3 \mathrm{H}, J=6.6 \mathrm{~Hz}), 0.90(\mathrm{t}, 3 \mathrm{H}, J=7.2 \mathrm{~Hz}) ;{ }^{13} \mathrm{C}$ NMR $\left(100 \mathrm{MHz}, \mathrm{CDCl}_{3}\right) \delta 169.4$, 86.2, 79.6, 79.2, 37.4, 30.8, 23.5, 22.1, 21.9, 18.4, 17.5, 17.2, 13.6; IR (neat): 2965, 2936, 2876, 2244, 1746, 1559, 1458, 1436, 1371, 1336, 1243, 1129, 1060, 1014, 942; MS (ES ${ }^{+}$) Calculated for $\left[\mathrm{C}_{13} \mathrm{H}_{22} \mathrm{NaO}_{2}\right]^{+}:$233.2; Found: 233.2.

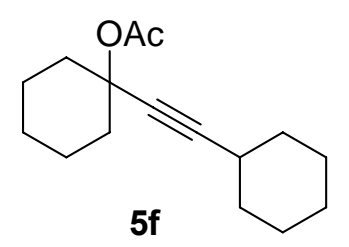

Compound $\mathbf{5 f}$ was prepared in $91 \%$ yield according to the general procedure $A$. ${ }^{1} \mathrm{H}$ NMR $\left(400 \mathrm{MHz}, \mathrm{CDCl}_{3}\right) \delta 2.47-2.43(\mathrm{~m}, 1 \mathrm{H}), 2.13-2.08(\mathrm{~m}, 2 \mathrm{H}), 2.02(\mathrm{~s}, 3 \mathrm{H}), 1.82-$ $1.24(\mathrm{~m}, 18 \mathrm{H}) ;{ }^{13} \mathrm{C}$ NMR $\left(100 \mathrm{MHz}, \mathrm{CDCl}_{3}\right) \delta 169.2,91.0,80.2,76.2,37.5,32.6,28.9$, 26.0, 25.3, 24.6, 22.9, 22.2; IR (neat): 2933, 2857, 2663, 2237, 1746, 1615, 1447, 1367, 1229, 1184, 1022; MS (ES ${ }^{+}$) Calculated for $\left[\mathrm{C}_{16} \mathrm{H}_{24} \mathrm{NaO}_{2}\right]^{+}:$271.2; Found: 271.1. 


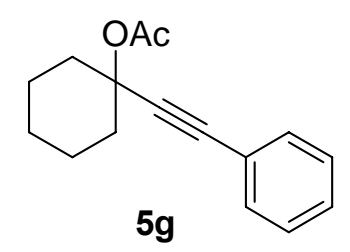

Compound $\mathbf{5 g}$ was prepared in $88 \%$ yield according to the general procedure $\mathrm{A}$. ${ }^{1} \mathrm{H} \mathrm{NMR}\left(500 \mathrm{MHz}, \mathrm{CDCl}_{3}\right)$ \& $7.46-7.44(\mathrm{~m}, 2 \mathrm{H}), 7.29-7.28(\mathrm{~m}, 3 \mathrm{H}), 2.24-2.19(\mathrm{~m}, 2 \mathrm{H})$, $2.07(\mathrm{~s}, 3 \mathrm{H}), 1.93-1.88(\mathrm{~m}, 2 \mathrm{H}), 1.70-1.65(\mathrm{~m}, 4 \mathrm{H}), 1.59-1.53(\mathrm{~m}, 1 \mathrm{H}), 1.39-1.33(\mathrm{~m}$, $1 \mathrm{H}) ;{ }^{13} \mathrm{C}$ NMR $\left(125 \mathrm{MHz}, \mathrm{CDCl}_{3}\right) \delta 169.2,131.8,128.2,128.1,122.8,89.1,86.2,75.9$, 37.1, 25.2, 22.7, 22.0; IR (neat):3082, 3057, 3035, 3023, 2937, 2861, 2667, 2229, 2203, 1743, 1675, 1599, 1573, 1491, 1444, 1367, 1346,1312, 1264, 1229, 1163, 1138, 1071 , 1041, 1022, 959; MS (ES ${ }^{+}$) Calculated for $\left[\mathrm{C}_{16} \mathrm{H}_{18} \mathrm{NaO}_{2}\right]^{+}:$265.3; Found: 265.2 .

\section{Preparation propargylic acetate $3 \mathrm{~h}$}

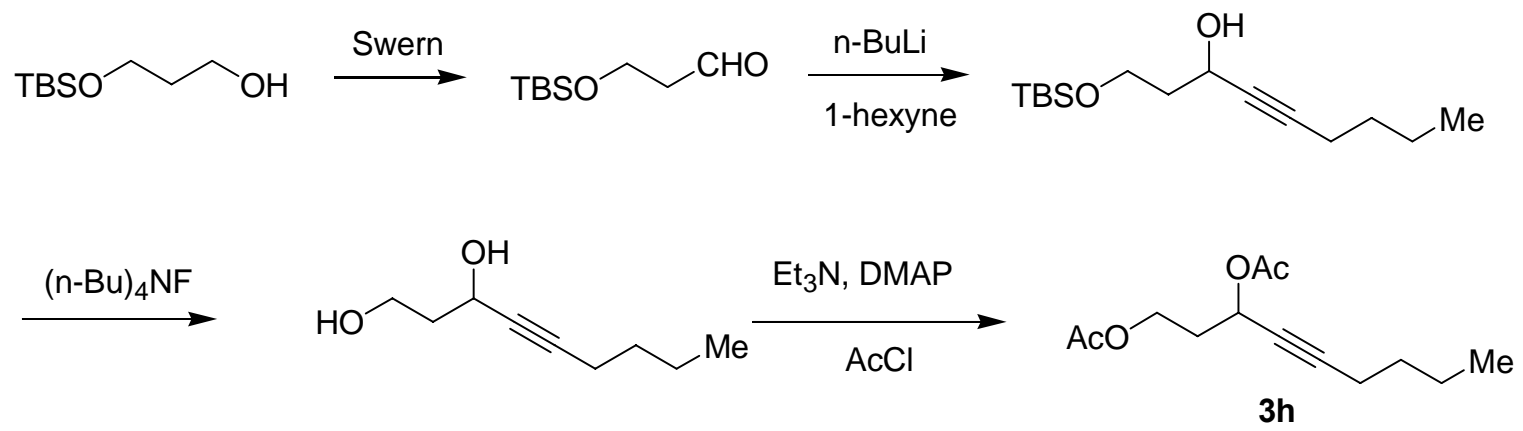

A solution oxalyl chloride $(1.9 \mathrm{~g}, 10 \mathrm{mmol})$ in DCM $(110 \mathrm{~mL})$ was cooled in a dry ice-acetone bath under nitrogen. To the solution was added dropwise anhydrous DMSO (1.6 $\mathrm{mL}, 22 \mathrm{mmol}$ ). After the addition, the reaction was kept at $-78^{\circ} \mathrm{C}$ for half an hour. A solution of mono-TBS protected propane-1,3-diol $(1.9 \mathrm{~g}, 10 \mathrm{mmol})$ in DCM $(20 \mathrm{~mL})$ was added dropwise, and the reaction mixture was stirred at $-78^{\circ} \mathrm{C}$ for 1 hour. The reaction was quenched by addition of $\mathrm{Et}_{3} \mathrm{~N}(6.9 \mathrm{~mL}, 50 \mathrm{mmol})$. The reaction was allowed to warm to room temperature. The organic layer was successively washed with saturated $\mathrm{NH}_{4} \mathrm{Cl}$ $(100 \mathrm{~mL})$ and brine $(100 \mathrm{~mL})$. the resulting organic layer was dried upon anhydrous $\mathrm{MgSO}_{4}$, filtered, concentrated in vacuo to give the crude aldehyde $(2.3 \mathrm{~g})$ which could be used in the next step without further purification.

A solution of 1-hexyne $(1.30 \mathrm{~g}, 15.8 \mathrm{mmol})$ in $\mathrm{THF}(50 \mathrm{ml})$ was cooled to $-78^{\circ} \mathrm{C}$ in a dry ice-acetone bath under nitrogen, and n-BuLi (1.6M in Hexane, 9.17 mL, 14.64 
mmol) was added dropwise in 15 mins. After the addition, a solution of the crude aldehyde $(2.3 \mathrm{~g}, 12.2 \mathrm{mmol})$ in THF $(10 \mathrm{~mL})$ was added dropwise, the resulting reaction mixture was allowed to warm to room temperature gradually. The reaction was quenched by addition of saturated $\mathrm{NH}_{4} \mathrm{Cl}(30 \mathrm{~mL})$. The aqueous layer was extracted with $\mathrm{Et}_{2} \mathrm{O}(3 \times 50 \mathrm{~mL})$. The combined organic layer was washed with brine $(100 \mathrm{~mL})$, dried with $\mathrm{MgSO}_{4}$, filtered, and concentrated to give an oil. The desired alcohol was purified by bulb-to-bulb distillation as a clear liquid ( $1.4 \mathrm{~g}, 50 \%$ yield two steps)

To a solution of the above alcohol $(270 \mathrm{mg}, 1 \mathrm{mmol})$ in THF $(5 \mathrm{~mL})$ was added TBAF (1M in THF, $1 \mathrm{~mL}$ ). The resulting mixture was stirred at room temperature for 2 hours. The reaction was cooled down in an ice-water bath, and $\mathrm{Et}_{3} \mathrm{~N}(0.3 \mathrm{~mL}, 3 \mathrm{mmol})$ and DMAP (cat) were added followed by dropwise addition of $\mathrm{CH}_{3} \mathrm{COCl}(0.18 \mathrm{~mL}, 2.5$ $\mathrm{mmol}$ ). The resulting mixture was allowed to rise to room temperature and stir for 4 hours. The reaction was quenched by addition of water $(20 \mathrm{~mL})$. The organic layer was extracted with $\mathrm{Et}_{2} \mathrm{O}(3 \times 15 \mathrm{~mL})$. The combined organic layer was washed with brine (50 $\mathrm{mL}$ ), dried upon $\mathrm{MgSO}_{4}$, filtered, and concentrated to give an oily residue, which was purified by flash-column to give diacetate $3 \mathrm{~h}$ (160 mg, 67\% yield). ${ }^{1} \mathrm{H}$ NMR (400 MHz, $\left.\mathrm{CDCl}_{3}\right) \delta 5.47(\mathrm{tt}, 1 \mathrm{H}, J=6.8,2.0 \mathrm{~Hz}), 4.25-4.15(\mathrm{~m}, 2 \mathrm{H}), 2.20(\mathrm{td}, 2 \mathrm{H}, J=6.8,2.0 \mathrm{~Hz})$, 2.13-2.03 (m, 8H), 1.51-1.45 (m, 2H), 1.41-1.36 (m, 2H), $0.90(\mathrm{t}, 3 \mathrm{H}, J=6.8 \mathrm{~Hz}) ;{ }^{13} \mathrm{C}$ NMR $\left(125 \mathrm{MHz} \mathrm{CDCl}_{3}\right) \delta 170.9,170.0,87.0,76.5,61.5,60.4,34.1,30.4,21.9,21.0$, 20.9, 18.3, 13.5; IR (neat): 2960, 2936, 2874, 2247, 1744, 1592, 1459, 1432, 1370, 1232, 1159, 1045, 960; MS (ES ${ }^{+}$Calculated for $\left[\mathrm{C}_{13} \mathrm{H}_{20} \mathrm{NaO}_{4}\right]^{+}:$263.1; Found: 263.2.

\section{Preparation propargylic acetate $\mathbf{3 i}$}
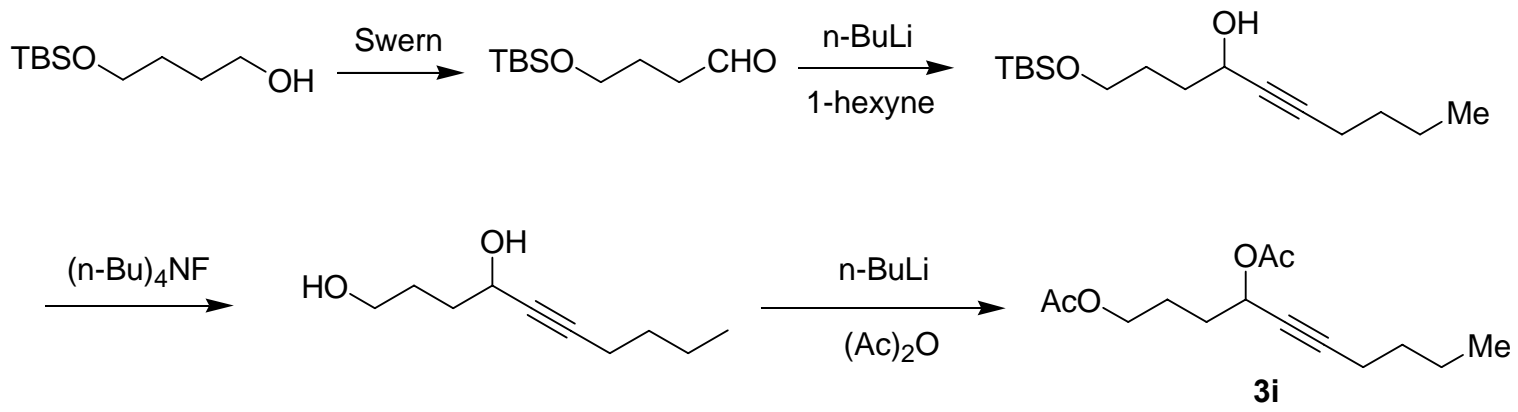

A solution oxalyl chloride $(0.4 \mathrm{~g}, 2 \mathrm{mmol})$ in $\mathrm{DCM}(20 \mathrm{~mL})$ was cooled to $-78^{\circ} \mathrm{C}$ in a dry ice-acetone bath under nitrogen. To the solution was added dropwise anhydrous DMSO (0.32 mL, $4.4 \mathrm{mmol})$. After addition, the reaction was kept at $-78^{\circ} \mathrm{C}$ for half an 
hour. A solution of mono-TBS protected butane-1,4-diol $(0.38 \mathrm{~g}, 2 \mathrm{mmol})$ in DCM (4 mL) was added dropwise, and the resulting mixture was stirred at $-78^{\circ} \mathrm{C}$ for 1 hour. The reaction was quenched by the addition of $\mathrm{Et}_{3} \mathrm{~N}(1.38 \mathrm{~mL}, 10 \mathrm{mmol})$. The reaction was allowed to warm to room temperature. The organic layer was successively washed with saturated $\mathrm{NH}_{4} \mathrm{Cl}(20 \mathrm{~mL})$ and brine $(20 \mathrm{~mL})$. The resulting organic layer was dried with anhydrous $\mathrm{MgSO}_{4}$, filtered, and concentrated in vacuo to give the crude aldehyde, which was used in the next step without further purification.

A solution of 1-hexyne $(0.13 \mathrm{~g}, 0.16 \mathrm{mmol})$ in THF $(10 \mathrm{ml})$ was cooled to $-78^{\circ} \mathrm{C}$ in a dry ice-acetone bath under nitrogen, and n-BuLi (1.6M in Hexane, $1 \mathrm{~mL}, 1.6 \mathrm{mmol}$ ) was added dropwise. The resulting mixture was stirred for 15 mins, and a solution of aldehyde $(0.23 \mathrm{~g}, 1.2 \mathrm{mmol})$ in THF $(10 \mathrm{~mL})$ was added dropwise. Upon the addition, the reaction mixture was allowed to warm to room temperature and stired for $15 \mathrm{~min}$. The reaction was quenched by the addition of saturated $\mathrm{NH}_{4} \mathrm{Cl}(10 \mathrm{~mL})$. The aqueous layer was extracted with $\mathrm{Et}_{2} \mathrm{O}(3 \times 20 \mathrm{~mL})$. The combined organic layer was washed with brine $(50 \mathrm{~mL})$, dried upon $\mathrm{MgSO}_{4}$, filtered, and concentrated to give an oily residue, which was purified by flash-column to give the desired alcohol ( $0.2 \mathrm{~g}, 35 \%$ yield, two steps)

To a solution of the alcohol $(90 \mathrm{mg}, 0.3 \mathrm{mmol})$ in THF $(5 \mathrm{~mL})$ was added the TBAF (1M in THF, $0.3 \mathrm{~mL}, 0.3 \mathrm{mmol}$ ). The resulting mixture was stirred at room temperature for 2 hours. The reaction cooled down to $-78^{\circ} \mathrm{C}$ in a dry ice-acetone bath under nitrogen, and n-BuLi (1.6M in Hexane, $0.37 \mathrm{~mL}, 0.6 \mathrm{mmol})$ was added dropwise. Upon the addition, the reaction mixture was stirred for $15 \mathrm{~min}$, and a solution of acetic anhydrdie $(0.12 \mathrm{~g}, 0.6 \mathrm{mmol})$ in THF $(2 \mathrm{~mL})$ was added dropwise. The reaction was allowed to warm to room temperature and kept stirring for half an hour. The reaction was quenched by addition of saturated $\mathrm{NH}_{4} \mathrm{Cl}(10 \mathrm{~mL})$. The aqueous layer was extracted with $\mathrm{Et}_{2} \mathrm{O}(3 \times 10 \mathrm{~mL})$. The combined organic layer was washed with brine $(50 \mathrm{~mL})$, dried upon $\mathrm{MgSO}_{4}$, filtered, and concentrated to give an oily residue, which was purified by flash-column to give diacetate $3 \mathbf{i}$ (60 mg, 83\% yield two steps). ${ }^{1} \mathrm{H}$ NMR (400 $\mathrm{MHz}$, $\left.\mathrm{CDCl}_{3}\right) \delta 5.40-5.38(\mathrm{~m}, 1 \mathrm{H}), 4.10(\mathrm{t}, 2 \mathrm{H}, J=4.8 \mathrm{~Hz}), 2.21(\mathrm{t}, 2 \mathrm{H}, J=6.8 \mathrm{~Hz}), 2.08(\mathrm{~s}, 3 \mathrm{H})$, $2.06(\mathrm{~s}, 3 \mathrm{H}), 1.83-1.74(\mathrm{~m}, 4 \mathrm{H}), 1.48$ (sextet, 2H, J = $8 \mathrm{~Hz}$ ), 1.39 (sextet, 2H, J = $8 \mathrm{~Hz}$ ), $0.91(\mathrm{t}, 3 \mathrm{H}, \mathrm{J}=7.6 \mathrm{~Hz}) ;{ }^{13} \mathrm{C}$ NMR $\left(100 \mathrm{MHz}, \mathrm{CDCl}_{3}\right) \delta 171.1,170.0,86.7,64.0,63.9$, 31.7, 30.5, 24.3, 21.9, 21.1, 21.0, 18.4, 13.6; IR (neat): 3308, 2960, 2935, 2337, 1741, 1592, 1430, 1370, 1232, 1023; MS $\left(\mathrm{ES}^{+}\right)$Calculated for $\left[\mathrm{C}_{14} \mathrm{H}_{22} \mathrm{NaO}_{4}\right]^{+}: 277.1$; Found: 277.2. 


\section{General procedure B: Preparation of $\alpha$-iodoenone 4 and 6}

To a solution of propargylic acetate 3 or $5(0.2 \mathrm{mmol})$ in anhydrous acetone $(4 \mathrm{~mL})$ cooled in ice-water bath were added $\mathrm{H}_{2} \mathrm{O}(0.005 \mathrm{ml}, 1.39 \mathrm{eq})$ and $\mathrm{Au}\left(\mathrm{PPh}_{3}\right) \mathrm{NTf}_{2}(0.05 \mathrm{M}$ in acetone, $0.08 \mathrm{~mL})$. The solution was treated with NIS $(0.24 \mathrm{mmol}, 1.2 \mathrm{eq})$. The reaction was stirred for two hours before quenched with $\mathrm{NEt}_{3}$ ( 1 drop) and aqueous $\mathrm{Na}_{2} \mathrm{~S}_{2} \mathrm{O}_{3}(5 \mathrm{~mL})$. The mixture was extracted with $\mathrm{Et}_{2} \mathrm{O}(3 \times 8 \mathrm{~mL})$. The combined organic phases were washed with $\mathrm{H}_{2} \mathrm{O}(10 \mathrm{~mL})$ and brine $(10 \mathrm{~mL})$, dried with anhydrous $\mathrm{MgSO}_{4}$, and filtered. The filtrate was concentrated, and the residue was purified through silica gel flash column chromatography (hexanes/ethyl acetate $=50 / 1$ ) to yield the desired $\alpha$-iodo$\alpha, \beta$-unsaturated ketones $\mathbf{4}$ or $\mathbf{6}$

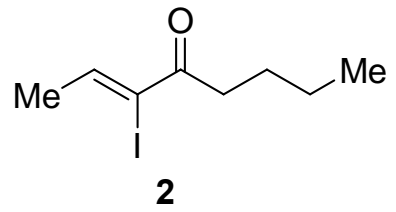

Compound 2 was prepared as a mixture of geometrical isomers $(Z / E=45 / 1)$ in 89\% yield according to the general procedure B. ${ }^{1} \mathrm{H}$ NMR $\left(400 \mathrm{MHz}, \mathrm{CDCl}_{3}\right.$ ) (major isomer) $\delta$ $7.11(\mathrm{q}, 1 \mathrm{H}, J=6.8 \mathrm{~Hz}$ ), 2.81 (t, 2H, J = 7.6 Hz), 2.07 (d, 3H, J = 6.8 Hz), 1.63 (Quintet, $2 \mathrm{H}, J=7.6 \mathrm{~Hz}$ ), 1.34 (Sextet, $2 \mathrm{H}, J=7.6 \mathrm{~Hz}), 0.92(\mathrm{t}, 3 \mathrm{H}, J=7.6 \mathrm{~Hz}) ;{ }^{13} \mathrm{C}$ NMR (125 $\mathrm{MHz}, \mathrm{CDCl}_{3}$ ) (major isomer) $\delta 194.9,146.8,114.3,37.5,30.3,27.1,23.9,22.3,13.8$; IR (neat): 2958, 2932, 2871, 1702, 1683, 1611, 1464, 1413, 1373, 1288, 1262, 1238, 1288, $1262,1238,1171,1113,1072$; $M S\left(\mathrm{ES}^{+}\right)$Calculated for $\left[\mathrm{C}_{8} \mathrm{H}_{13} \mathrm{NaIO}\right]^{+}:$275.0; Found: 275.0 .

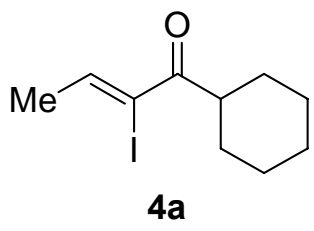

Compound 4a was isolated as a mixture of geometrical isomers $(Z / E=12 / 1)$ in $82 \%$ yield according to the general procedure B. ${ }^{1} \mathrm{H}$ NMR $\left(500 \mathrm{MHz}, \mathrm{CDCl}_{3}\right.$ ) (major isomer) $\delta$ $7.08(\mathrm{q}, 1 \mathrm{H}, \mathrm{J}=7.0 \mathrm{~Hz}$ ), 3.14 (q, 1H, J = 7.0 Hz), 2.08 (d, 3H, J = 7.0 Hz), 1.80-1.78 (m, $4 \mathrm{H}), 1.48-1.22(\mathrm{~m}, 6 \mathrm{H}) ;{ }^{13} \mathrm{C}$ NMR (125 MHz, $\mathrm{CDCl}_{3}$ ) (major isomer) $\delta 198.2,146.1$, 113.9, 45.4, 29.9, 25.8, 25.7, 24.0; IR (neat): 3019, 2932, 2855, 2664, 1678, 1611, 1463, 
1450, 1372, 1287, 1264, 1241, 1188, 1163, 1131, 1109, 1081, 1071, 1030, 974, 895, 884, 824; MS (ES $\left.{ }^{+}\right)$Calculated for $\left[\mathrm{C}_{10} \mathrm{H}_{15} \mathrm{NalO}^{+}\right.$: 301.0; Found: 300.9.

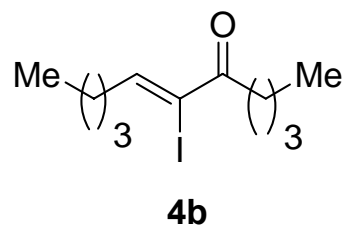

Compound $\mathbf{4 b}$ was prepared as a mixture of geometrical isomers $(Z / E=10 / 1)$ in $94 \%$ yield according to the general procedure B. Compound $\mathbf{4 b}$ (major isomer): ${ }^{1} \mathrm{H}$ NMR (400 $\left.\mathrm{MHz}, \mathrm{CDCl}_{3}\right) \delta 6.99(\mathrm{t}, 1 \mathrm{H}, J=6.8 \mathrm{~Hz}$ ), $2.82(\mathrm{t}, 2 \mathrm{H}, J=7.2 \mathrm{~Hz}), 2.42(\mathrm{q}, 2 \mathrm{H}, J=7.6 \mathrm{~Hz}$ ), 1.67-1.50 (m, 4H), 1.45-1.30 (m, 4H), 0.97-0.89 (m, 6H); ${ }^{13} \mathrm{C}$ NMR $\left(125 \mathrm{MHz}, \mathrm{CDCl}_{3}\right) \delta$ 195.0, 151.2, 112.4, 37.7, 37.6, 29.7, 27.1, 22.4, 22.3, 13.8, 13.8; IR (neat): 3351, 2958, 2930, 2872, 2735, 1683, 1604, 1465, 1413, 1379, 1291, 1236, 1167, 1123, 1088, 934; MS (ES $\left.{ }^{+}\right)$Calculated for $\left[\mathrm{C}_{11} \mathrm{H}_{19} \mathrm{INaO}\right]^{+}$: 317.0; Found: 317.0.

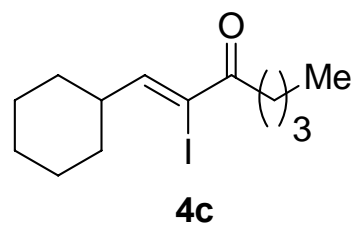

Compound $4 c$ was prepared as a mixture of geometrical isomers $(Z / E=19 / 1)$ in $91 \%$ yield according to the general procedure B with exceptions that $10 \mathrm{~mol} \%$ of $\mathrm{AgNTf}_{2}$ was added together with $\mathrm{Au}\left(\mathrm{PPh}_{3}\right) \mathrm{NTf}_{2}$ and a column basified with $\mathrm{Et}_{3} \mathrm{~N}$ was used for purification. Compound 4c (major isomer): ${ }^{1} \mathrm{H}$ NMR $\left(500 \mathrm{MHz}, \mathrm{CDCl}_{3}\right) \delta 6.74(\mathrm{~d}, 1 \mathrm{H}, \mathrm{J}=$ $9 \mathrm{~Hz}$ ), $2.80(\mathrm{t}, 2 \mathrm{H}, J=15 \mathrm{~Hz}), 2.60-2.52(\mathrm{~m}, 1 \mathrm{H}), 1.82-1.68(\mathrm{~m}, 5 \mathrm{H}), 1.60$ (quintet, $2 \mathrm{H}, J$ $=7.5 \mathrm{~Hz}), 1.41-1.31(\mathrm{~m}, 4 \mathrm{H}), 1.27-1.20(\mathrm{~m}, 3 \mathrm{H}), 1.92(\mathrm{t}, 3 \mathrm{H}, J=7.5 \mathrm{~Hz}) ;{ }^{13} \mathrm{C}$ NMR $(125$ $\left.\mathrm{MHz}, \mathrm{CDCl}_{3}\right) \delta 195.3,155.7,109.9,46.8,37.6,30.7,27.2,25.7,25.2,22.3,13.8$; IR (neat): 3351, 2928, 2852, 2662, 2351, 1683, 1601, 1448, 1278, 1224, 1169, 1128, 1089, 968; MS (ES $\left.{ }^{+}\right)$Calculated for $\left[\mathrm{C}_{13} \mathrm{H}_{21} \mathrm{INaO}^{+}:\right.$: 343.1; Found: 343.0 .

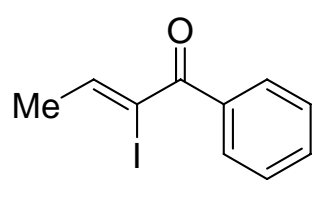

Z-4d 
Compound 4d was prepared in 75\% yield in a 1.2:1 Z/E ratio of separable isomers according to the general procedure B. Compound Z-4d: ${ }^{1} \mathrm{H}$ NMR $\left(400 \mathrm{MHz}, \mathrm{CDCl}_{3}\right) \delta$ 7.69 (d, 2H, J = $8 \mathrm{~Hz}), 7.55$ (t, 2H, J = $8 \mathrm{~Hz}), 7.44$ (t, 2H, J = $8 \mathrm{~Hz}), 6.73$ (q, 1H, J = $8 \mathrm{~Hz})$, 2.09 (d, 3H, J = $8 \mathrm{~Hz}) ;{ }^{13} \mathrm{C}$ NMR $\left(125 \mathrm{MHz}, \mathrm{CDCl}_{3}\right) \delta 191.9,149.7,135.8,132.4,129.6$, 128.4, 110.5, 23.6; IR (neat): 3297, 3059, 2924, 2851, 2356, 1993, 1658, 1606, 1577, 1446, 1371, 1314, 1260, 1179, 1120, 1060,1025, 965 MS (ES ${ }^{+}$) Calculated for $\left[\mathrm{C}_{10} \mathrm{H}_{9} \mathrm{INaO}\right]^{+}:$295.0; Found: 295.0 .

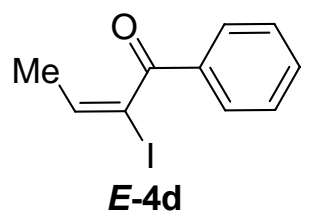

Compound $\boldsymbol{E}-\mathbf{4 d}:{ }^{1} \mathrm{H}$ NMR $\left(400 \mathrm{MHz}, \mathrm{CDCl}_{3}\right) \delta \delta 7.98(\mathrm{~d}, 2 \mathrm{H}, \mathrm{J}=8 \mathrm{~Hz}), 7.61(\mathrm{t}, 2 \mathrm{H}, J=8$ $\mathrm{Hz}), 7.49$ (t, 2H, J = $8 \mathrm{~Hz}), 6.67(\mathrm{q}, 1 \mathrm{H}, J=8 \mathrm{~Hz}), 1.67$ (d, 3H, J = $8 \mathrm{~Hz}) ;{ }^{13} \mathrm{C}$ NMR (125 $\mathrm{MHz}_{\mathrm{CDCl}}$ ) $\delta 192.7,140.8,134.0,133.6,129.9,128.9,90.4,18.7$; IR (neat): 3053, 2916, 2850, 2347, 1666, 1596, 1448, 1329, 1227, 1174, 1115, 1012; MS (ES $)$ Calculated for $\left[\mathrm{C}_{10} \mathrm{H}_{9} \mathrm{INaO}\right]^{+}:$295.0; Found: 295.0.

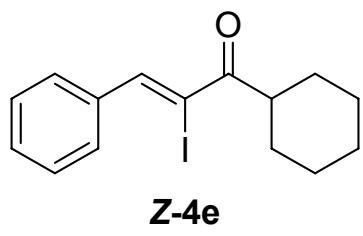

Compound $4 \mathrm{e}$ was prepared in $97 \%$ yield in a 1:2 Z/E ratio of separable isomers according to the general procedure B. Compound Z-4e: ${ }^{1} \mathrm{H}$ NMR $\left(500 \mathrm{MHz}, \mathrm{CDCl}_{3}\right) \delta$ 7.96 (s, 1H), 7.75-7.70 (m, 2H), 7.46-7.43 (m, 3H), 3.33 (tt, 1H, J = 11.5, 3 Hz,), 1.92$1.83(\mathrm{~m}, 4 \mathrm{H}), 1.74-1.72(\mathrm{~m}, 1 \mathrm{H}), 1.54-1.46(\mathrm{~m}, 2 \mathrm{H}), 1.42-1.23(\mathrm{~m}, 3 \mathrm{H}) ;{ }^{13} \mathrm{C}$ NMR (125 $\left.\mathrm{MHz}_{\mathrm{CDCl}}\right) \delta 199.5,145.6,135.9,130.0,129.5,128.3,107.2,45.6,30.0,25.8$; IR (neat): 3334, 3057, 3023, 2930, 2853, 2662, 1674, 1591, 1491, 1445, 1366, 1262, 1186, 1150, 1112, 1013, 925; MS (ES $\left.{ }^{+}\right)$Calculated for $\left[\mathrm{C}_{15} \mathrm{H}_{17} \mathrm{INaO}\right]^{+}:$363.0; Found: 362.9 . 


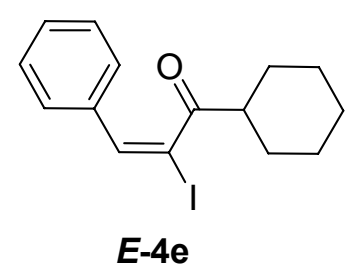

Compound E-4e: ${ }^{1} \mathrm{H}$ NMR $\left(500 \mathrm{MHz}, \mathrm{CDCl}_{3}\right) \delta 7.46(\mathrm{~s}, 1 \mathrm{H}), 7.32-7.31(\mathrm{~m}, 3 \mathrm{H}), 7.19-$ $7.17(\mathrm{~m}, 2 \mathrm{H}), 2.47(\mathrm{tt}, 1 \mathrm{H}, J=11,3.5 \mathrm{~Hz}),, 1.82(\mathrm{~d}, 2 \mathrm{H}, J=11.5 \mathrm{~Hz}), 1.68-1.54(\mathrm{~m}, 2 \mathrm{H})$, 1.58-1.54 (m, 1H), 1.39-1.32 (m, 2H), 1.16-1.02 (m, 3H); $\left.{ }^{13} \mathrm{C} \mathrm{NMR} \mathrm{(125} \mathrm{MHz,} \mathrm{CDCl}\right) \delta$ 206.3, 143.0, 136.7, 129.0, 129.6, 128.1, 96.3, 49.5, 29.5, 25.6, 25.6; IR (neat): 3352, 3057, 3024, 2930, 2853, 2662, 1687, 1598, 1572, 1494, 1448, 1366, 1312, 1289, 1236, 1141, 1071, 1007, 926, 814; MS $\left(\mathrm{ES}^{+}\right)$Calculated for $\left[\mathrm{C}_{15} \mathrm{H}_{17} \mathrm{INaO}\right]^{+}: 363.0$; Found: 362.9 .

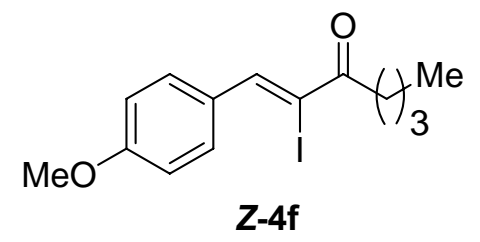

Compound $\mathbf{4 f}$ was prepared in $84 \%$ yield in a 1.05:1 Z/E ratio of separable isomers according to the general procedure B. Compound Z-4f: ${ }^{1} \mathrm{H}$ NMR $\left(400 \mathrm{MHz}, \mathrm{CDCl}_{3}\right) \delta$ $8.02(\mathrm{~s}, 1 \mathrm{H}), 7.90(\mathrm{~d}, 2 \mathrm{H}, J=8.8 \mathrm{~Hz}), 6.98(\mathrm{~d}, 2 \mathrm{H}, J=8.8 \mathrm{~Hz}), 3.87(\mathrm{~s}, 3 \mathrm{H}), 2.97(\mathrm{t}, 2 \mathrm{H}, J$ $=8 \mathrm{~Hz}$ ), 1.70 (quintet, $2 \mathrm{H}, J=7.2 \mathrm{~Hz}$ ), 1.39 (sextet, $2 \mathrm{H}, J=7.6 \mathrm{~Hz}$ ), $0.95(\mathrm{t}, 3 \mathrm{H}, J=7.2$ $\mathrm{Hz}) ;{ }^{13} \mathrm{C} \mathrm{NMR}\left(125 \mathrm{MHz}, \mathrm{CDCl}_{3}\right) \delta 195.9,161.4,146.1,132.0,127.6,113.8,104.6,55.4$, 37.8, 27.4, 22.4, 13.9; IR (neat): 3003, 2957, 2932, 2871, 2838, 1674, 1604, 1587, 1568, 1509, 1463, 1255, 1148,1029, 826; $\mathrm{MS}\left(\mathrm{ES}^{+}\right)$Calculated for $\left[\mathrm{C}_{14} \mathrm{H}_{17} \mid \mathrm{NaO}_{2}\right]^{+}: 367.0$; Found: 366.9 .

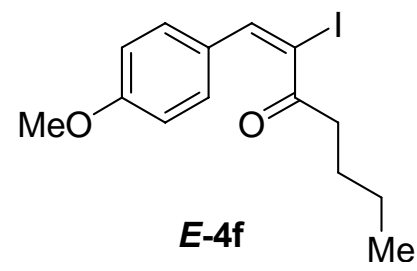

. Compound E-4f: ${ }^{1} \mathrm{H}$ NMR (400 MHz, $\left.\mathrm{CDCl}_{3}\right) \delta 7.36(\mathrm{~s}, 1 \mathrm{H}), 7.13(\mathrm{~d}, 2 \mathrm{H}, J=8.8 \mathrm{~Hz}$ ), $6.84(\mathrm{~d}, 2 \mathrm{H}, J=8.8 \mathrm{~Hz}$ ), $3.81(\mathrm{~s}, 3 \mathrm{H}$ ), $2.54(\mathrm{t}, 2 \mathrm{H}, J=7.6 \mathrm{~Hz}$ ), 1.56 (quintet, $2 \mathrm{H}, J=7.2$ $\mathrm{Hz}$ ), 1.24 (sextet, $2 \mathrm{H}, J=7.6 \mathrm{~Hz}), 0.83(\mathrm{t}, 3 \mathrm{H}, J=7.2 \mathrm{~Hz}) ;{ }^{13} \mathrm{C} \mathrm{NMR}\left(125 \mathrm{MHz}, \mathrm{CDCl}_{3}\right) \delta$ 
203.9, 160.2, 142.6, 129.7, 129.2, 114.0, 94.7, 55.3, 40.2, 26.4, 22.1, 13.7; IR (neat): $3271,2957,2930,2870,1685,1604,1509,1456,1293,1255,1178,1122,1032$; MS $\left(\mathrm{ES}^{+}\right)$Calculated for [C14H17INaO2] $]^{+}: 267.0$; Found: 267.0.

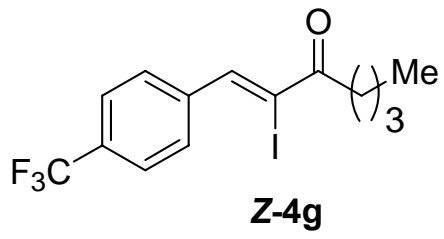

Compound $\mathbf{4 g}$ was prepared in $96 \%$ yield in a 5:1 Z/E ratio of separable isomers according to the general procedure B. Compound $\mathbf{Z}-\mathbf{4 g}:{ }^{1} \mathrm{H}$ NMR $\left(400 \mathrm{MHz}, \mathrm{CDCl}_{3}\right) \delta$ $8.00(\mathrm{~s}, 1 \mathrm{H}), 7.81(\mathrm{~d}, 2 \mathrm{H}, J=8.4 \mathrm{~Hz}), 7.70(\mathrm{~d}, 2 \mathrm{H}, J=8.4 \mathrm{~Hz}), 2.99(\mathrm{t}, 2 \mathrm{H}, J=7.2 \mathrm{~Hz})$, 1.71 (Quintet, $2 \mathrm{H}, J=7.2 \mathrm{~Hz}$ ), 1.40 (Sextet, $2 \mathrm{H}, J=7.2 \mathrm{~Hz}$ ), $0.96\left(\mathrm{t}, 3 \mathrm{H}, J=7.2 \mathrm{~Hz}\right.$ ); ${ }^{13} \mathrm{C}$ $\operatorname{NMR}\left(125 \mathrm{MHz}, \mathrm{CDCl}_{3}\right) \delta 196.2,144.8,139.8,131.6$ (q, $\left.\mathrm{J}_{\mathrm{C}-\mathrm{F}}=32.4 \mathrm{~Hz}\right), 129.8,125,6$ (q, $J_{C-F}=3.72 \mathrm{~Hz}$ ), $124.0\left(q, J_{C-F}=270.8 \mathrm{~Hz}\right.$ ), 110.2, 38.4, 27.3, 22.5, 14.1; IR (neat): 3070, 2960, 2934, 2874, 1681, 1598, 1466, 1412, 1324, 1168, 1128, 1068, 1017, 885, 827; MS $\left(\mathrm{ES}^{+}\right)$Calculated for $\left[\mathrm{C}_{14} \mathrm{H}_{14} \mathrm{NaF}_{3} \mathrm{lO}\right]^{+}:$405.0; Found: 404.9.

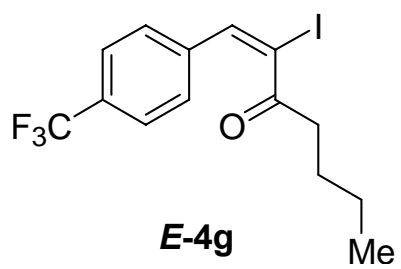

Compound E-4g: ${ }^{1} \mathrm{H}$ NMR (400 MHz, $\left.\mathrm{CDCl}_{3}\right) \delta 7.58(\mathrm{~d}, 2 \mathrm{H}, J=8.4 \mathrm{~Hz}), 7.38(\mathrm{~s}, 1 \mathrm{H})$, $7.31(\mathrm{~d}, 2 \mathrm{H}, J=8.4 \mathrm{~Hz}$ ), 2.55 (t, $2 \mathrm{H}, J=7.2 \mathrm{~Hz}$ ), 1.56 (Quintet, $2 \mathrm{H}, J=7.2 \mathrm{~Hz}$ ), 1.24 (Sextet, $2 \mathrm{H}, J=7.2 \mathrm{~Hz}$ ), $0.83\left(\mathrm{t}, 3 \mathrm{H}, J=7.2 \mathrm{~Hz}\right.$ ); ${ }^{13} \mathrm{C} \mathrm{NMR}\left(125 \mathrm{MHz}, \mathrm{CDCl}_{3}\right) \delta 203.0$, 140.7, 139.5, 130.7 (q, J J $J_{\text {-F }}=32.4 \mathrm{~Hz}$ ), 128.2, 125,7 (q, $\left.J_{C-F}=3.75 \mathrm{~Hz}\right), 123.8\left(q, J_{C-F}=\right.$ $270.6 \mathrm{~Hz}$ ), 99.68, 40.0, 26.0, 22.0, 13.7; IR (neat): 3070, 2960, 2923, 2870, 1699, 1597, $1459,1421,1324,1168,1126,1068,1017,874,830 ; \mathrm{MS}\left(\mathrm{ES}^{+}\right)$Calculated for $\left[\mathrm{C}_{14} \mathrm{H}_{14} \mathrm{NaF}_{3} \mathrm{OO}\right]^{+}$: 405.0; Found: 404.9.

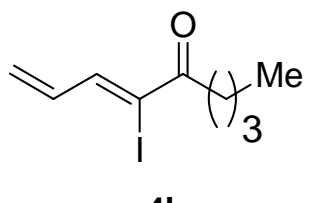

4h 
Compound $4 \mathrm{~h}$ was prepared in $80 \%$ yield according to the general procedure B. ${ }^{1} \mathrm{H}$ NMR $\left(500 \mathrm{MHz}, \mathrm{CDCl}_{3}\right) \delta 7.37$ (d, $\left.1 \mathrm{H}, J=10 \mathrm{~Hz}\right), 6.78(\mathrm{td}, 1 \mathrm{H}, J=16.5,10 \mathrm{~Hz}), 5.88(\mathrm{~d}, 1 \mathrm{H}, J$ $=17 \mathrm{~Hz}$ ), $5.76(\mathrm{~d}, 1 \mathrm{H}, J=10 \mathrm{~Hz}$ ), $2.87(\mathrm{t}, 2 \mathrm{H}, J=7.5 \mathrm{~Hz}$ ), 1.65 (Quintet, $2 \mathrm{H}, J=7.5 \mathrm{~Hz}$ ), 1.36 (sextet, $2 \mathrm{H}, J=7.5 \mathrm{~Hz}$ ), $0.93(\mathrm{t}, 3 \mathrm{H}, J=7.5 \mathrm{~Hz}) ;{ }^{13} \mathrm{C} \mathrm{NMR}\left(125 \mathrm{MHz}, \mathrm{CDCl}_{3}\right) \delta$ 195.4, 146.2, 139.3, 128.9, 110.6, 37.7, 27.1 22.3, 13.9; IR (neat): 3274, 2958, 2331, $1682,1597,1456,1597,1457,1261,1123,1042 . \mathrm{MS}^{\left(E S^{+}\right)}$Calculated for $\left[\mathrm{C}_{9} \mathrm{H}_{13} \mathrm{INaO}^{+}\right.$: 286.9; Found: 286.6.

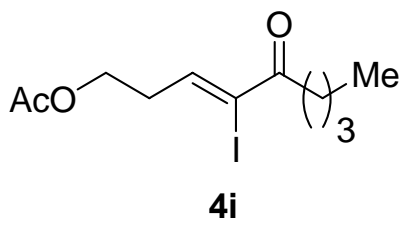

Compound $4 \mathbf{i}$ was prepared in $83 \%$ yield according to the general procedure $\mathrm{B} .{ }^{1} \mathrm{H}$ NMR $\left(400 \mathrm{MHz}, \mathrm{CDCl}_{3}\right) \delta 7.00(\mathrm{t}, 1 \mathrm{H}, J=6.8 \mathrm{~Hz}), 4.13(\mathrm{t}, 2 \mathrm{H}, J=6.4 \mathrm{~Hz}), 2.82(\mathrm{t}, 2 \mathrm{H}, J=7.2$ $\mathrm{Hz}$ ), $2.50(\mathrm{q}, 2 \mathrm{H}, J=7.2 \mathrm{~Hz}$ ), $2.07(\mathrm{~s}, 3 \mathrm{H}$ ), 1.90 (quintet, $2 \mathrm{H}, J=7.2 \mathrm{~Hz}$ ), 1.63 (quintet, $2 \mathrm{H}, J=7.6 \mathrm{~Hz}$ ), 1.35 (sextet, $2 \mathrm{H}, J=7.6 \mathrm{~Hz}$ ), $0.93(\mathrm{t}, 3 \mathrm{H}, J=6.8 \mathrm{~Hz}) ;{ }^{13} \mathrm{C}$ NMR $(125$ $\left.\mathrm{MHz}, \mathrm{CDCl}_{3}\right) \delta 194.9,171.0,149.8,113.0,63.5,37.7,34.6,27.1,26.7,22.3,21.0,13.8$; IR (neat): 3271, 2958, 2872, 1738, 1683, 1604, 1456, 1366, 1241, 1159, 1118, 1044; MS (ES $\left.{ }^{+}\right)$Calculated for $\left[\mathrm{C}_{12} \mathrm{H}_{19} \mathrm{INaO}_{3}\right]^{+}:$361.0; Found: 360.9 .

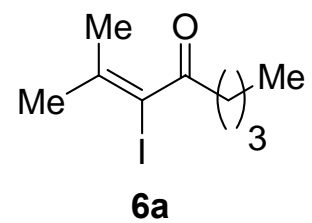

Compound 6a was prepared in 96\% yield according to the general procedure B. ${ }^{1} \mathrm{H}$ NMR $\left(400 \mathrm{MHz}, \mathrm{CDCl}_{3}\right) \delta 2.81(\mathrm{t}, 2 \mathrm{H}, J=7.2 \mathrm{~Hz}$ ), $2.03(\mathrm{~s}, 3 \mathrm{H}), 1,96(\mathrm{~s}, 3 \mathrm{H}), 1.61$ (Quintet, 2H, $J=7.2 \mathrm{~Hz}$ ), 1.35 (Sextet, 2H, $J=7.2 \mathrm{~Hz}$ ), $0.93(\mathrm{t}, 3 \mathrm{H}, J=7.2 \mathrm{~Hz}) ;{ }^{13} \mathrm{C}$ NMR $(125 \mathrm{MHz}$, $\left.\mathrm{CDCl}_{3}\right) \delta 202.3,144.3,95.5,40.5,30.3,26.4,22.3,21.9,13.8$; IR (neat): 2958, 2932, 2873, 1688, 1601, 1464, 1441, 1406, 1380, 1368, 1258, 1238, 1155, 1105, 1044, 910, 842; MS (ES $\left.{ }^{+}\right)$Calculated for $\left[\mathrm{C}_{9} \mathrm{H}_{15} \mathrm{NalO}\right]^{+}: 289.0$; Found: 289.0 . 


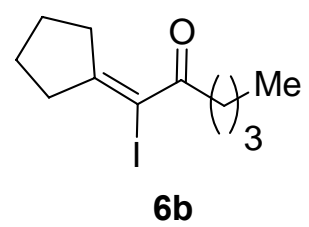

Compound $\mathbf{6 b}$ was prepared in $87 \%$ yield according to the general procedure B. ${ }^{1} \mathrm{H}$ NMR $\left(400 \mathrm{MHz}, \mathrm{CDCl}_{3}\right) \delta 2.85(\mathrm{t}, 2 \mathrm{H}, J=7.2 \mathrm{~Hz}), 2.70(\mathrm{tt}, 2 \mathrm{H}, J=7.2,1.2 \mathrm{~Hz}), 2.47(\mathrm{tt}, 2 \mathrm{H}, J$ = 7.2, $1.2 \mathrm{~Hz}$ ), 1.89 (Quintet, 2H, J = 7.2 Hz), 1.72 (Quintet, $2 \mathrm{H}, J=7.2 \mathrm{~Hz}$ ), 1.58 (Quintet, 2H, $J=7.2 \mathrm{~Hz}$ ), 1.34 (Sextet, $2 \mathrm{H}, J=7.2 \mathrm{~Hz}$ ), $0.92\left(\mathrm{t}, 3 \mathrm{H}, J=7.2 \mathrm{~Hz}\right.$ ); ${ }^{13} \mathrm{C}$ NMR $\left(125 \mathrm{MHz}, \mathrm{CDCl}_{3}\right) \delta$ 198.9, 166.4, 92.3, 44.4, 41.8, 36.1, 28.7, 26.9, 24.9, 22.3, 13.9; IR (neat): 2959, 2936, 2872, 1674, 1573, 1466, 1452, 1413, 1379, 1306, 1289, 1264, 1172, 1158, 1137, 1088, 911; MS (ES $\left.{ }^{+}\right)$Calculated for $\left[\mathrm{C}_{11} \mathrm{H}_{17} \mathrm{NalO}\right]^{+}$: 315.0; Found: 315.0.

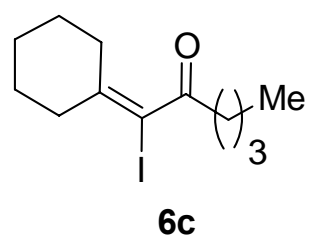

Compound $6 \mathbf{c}$ was prepared in $91 \%$ yield according to the general procedure B. ${ }^{1} \mathrm{H}$ NMR $\left(400 \mathrm{MHz}, \mathrm{CDCl}_{3}\right) \delta 2.79(\mathrm{t}, 2 \mathrm{H}, J=7.2 \mathrm{~Hz}), 2.41(\mathrm{t}, 2 \mathrm{H}, J=5.6 \mathrm{~Hz}), 2.33(\mathrm{t}, 2 \mathrm{H}, J=5.6$ $\mathrm{Hz}$ ), $1.66-1.50(\mathrm{~m}, 8 \mathrm{H}), 1.35$ (Sextet, $2 \mathrm{H}, J=7.2 \mathrm{~Hz}$ ), $0.93(\mathrm{t}, 3 \mathrm{H}, J=7.2 \mathrm{~Hz}) ;{ }^{13} \mathrm{C}$ NMR $\left(125 \mathrm{MHz}, \mathrm{CDCl}_{3}\right) \delta 202.5,149.2,92.4,40.3,39.6,32.9,28.0,27.4,26.3,25.9,22.3$, 13.8; IR (neat): 2957, 2932, 2857, 1694, 1606, 1464, 1448, 1404, 1350, 1260, 1221, $1145,1077,1069,984,854$; MS $\left(E^{+}\right)$Calculated for $\left[\mathrm{C}_{12} \mathrm{H}_{19} \mathrm{NalO}\right]^{+}$: 329.0; Found: 329.0 .

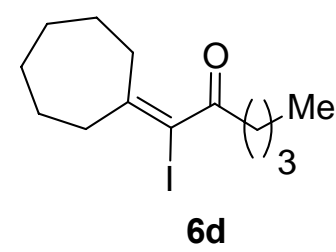

Compound $6 \mathrm{~d}$ was prepared in $99 \%$ yield according to the general procedure B. ${ }^{1} \mathrm{H}$ NMR $\left(400 \mathrm{MHz}, \mathrm{CDCl}_{3}\right) \delta 2.80(\mathrm{t}, 2 \mathrm{H}, J=7.2 \mathrm{~Hz}), 2.47-2.42(\mathrm{~m}, 4 \mathrm{H}), 1.69-1.49(\mathrm{~m}, 10 \mathrm{H})$, 1.35 (Sextet, $2 \mathrm{H}, J=7.2 \mathrm{~Hz}$ ), $0.93\left(\mathrm{t}, 3 \mathrm{H}, J=7.2 \mathrm{~Hz}\right.$ ); ${ }^{13} \mathrm{C} \mathrm{NMR}\left(125 \mathrm{MHz}, \mathrm{CDCl}_{3}\right) \delta$ 202.4, 151.4, 96.1, 41.5, 40.4, 33.5, 29.2, 28.5, 28.0, 26.4, 26.1, 22.3, 13.8; IR (neat): 2956, 2927, 2857, 1688, 1599, 1464, 1457, 1404, 1351, 1266, 1160, 1132, 1081, 957, 909; $\mathrm{MS}\left(\mathrm{ES}^{+}\right)$Calculated for $\left[\mathrm{C}_{13} \mathrm{H}_{21} \mathrm{NalO}^{+}\right.$: 343.0; Found: 343.0. 


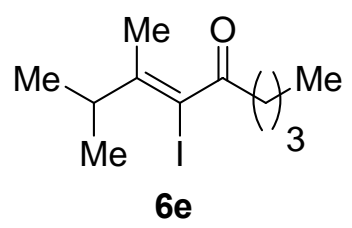

Compound $6 \mathbf{e}$ was isolated as a mixture of geometrical isomers $(Z / E=1 / 2.31)$ in $88 \%$ yield according to the general procedure B. ${ }^{1} \mathrm{H} \mathrm{NMR}\left(500 \mathrm{MHz}, \mathrm{CDCl}_{3}\right.$ ) (major isomer) $\delta 2.83$ (Quintet, $1 \mathrm{H}, J=7.0 \mathrm{~Hz}$ ), 2.79 (t, $2 \mathrm{H}, J=7.5 \mathrm{~Hz}$ ), 1.88 (s, 3H), 1.61 (Quintet, $2 \mathrm{H}$, $J=7.5 \mathrm{~Hz}$ ), 1.35 (Quintet, 2H, $J=7.5 \mathrm{~Hz}$ ), $1.02(\mathrm{~d}, 6 \mathrm{H}, J=7.0 \mathrm{~Hz}$ ), $0.93(\mathrm{t}, 3 \mathrm{H}, J=7.5$ $\mathrm{Hz}$ ); ${ }^{1} \mathrm{H}$ NMR (500 MHz, $\mathrm{CDCl}_{3}$ ) (minor isomer) $\delta 2.94$ (Quintet, $\left.1 \mathrm{H}, J=7.0 \mathrm{~Hz}\right), 2.78(\mathrm{t}$, $2 \mathrm{H}, J=7.5 \mathrm{~Hz}$ ), 1.77 (s, 3H), 1.61 (Quintet, 2H, $J=7.5 \mathrm{~Hz}$ ), 1.35 (Quintet, 2H, $J=7.5$ $\mathrm{Hz}$ ), $1.02\left(\mathrm{~d}, 6 \mathrm{H}, J=7.0 \mathrm{~Hz}\right.$ ), $0.93(\mathrm{t}, 3 \mathrm{H}, J=7.5 \mathrm{~Hz}){ }^{13} \mathrm{C} \mathrm{NMR}\left(125 \mathrm{MHz}, \mathrm{CDCl}_{3}\right.$ ) (major isomer) $\delta 202.5,150.6,95.9,40.3,39.8,33.5,26.3,22.3,21.0,19.7,13.8 ;{ }^{13} \mathrm{C}$ NMR $\left(125 \mathrm{MHz}, \mathrm{CDCl}_{3}\right.$ ) (minor isomer) $\delta 202.7,149.5,93.9,40.3,39.8,33.5,26.3,22.3,21.6$, 14.6, 13.8; IR (neat): 2962, 2932, 2872, 1695, 1620, 1615, 1464, 1404, 1385, 1363, 1342, 1225, 1151, 1101, 1062, 983, 900; MS (ES $\left.{ }^{+}\right)$Calculated for $\left[\mathrm{C}_{11} \mathrm{H}_{19} \mathrm{NalO}\right]^{+}: 317.1$; Found: 317.0 .

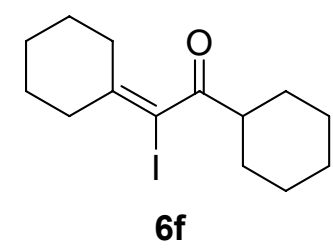

Compound 6 f was prepared in $96 \%$ yield according to the general procedure B. ${ }^{1} \mathrm{H}$ NMR $\left(500 \mathrm{MHz}, \mathrm{CDCl}_{3}\right) \delta 3.03(\mathrm{tt}, 1 \mathrm{H}, J=11,3.0 \mathrm{~Hz}), 2.42(\mathrm{t}, 2 \mathrm{H}, J=7.5 \mathrm{~Hz}), 2.30(\mathrm{t}, 2 \mathrm{H}, J=$ $6 \mathrm{~Hz}), 1.92(\mathrm{~d}, 2 \mathrm{H}, \mathrm{J}=12.5 \mathrm{~Hz}), 1.80-1.77(\mathrm{~m}, 2 \mathrm{H}), 1.69-1.50(\mathrm{~m}, 7 \mathrm{H}), 1.41-1.10(\mathrm{~m}$, $5 \mathrm{H}) ;{ }^{13} \mathrm{C}$ NMR $\left(125 \mathrm{MHz}, \mathrm{CDCl}_{3}\right) \delta 204.9,149.4,91.8,47.5,39.6,33.4,28.8,28.0,27.4$, 25.9, 25.8, 25.7; IR (neat): 3351, 2930, 2853, 2609, 1684, 1616, 1448, 1350, 1309, 1219, 1149, 1084, 982; MS (ES $\left.{ }^{+}\right)$Calculated for $\left[\mathrm{C}_{14} \mathrm{H}_{21} \mathrm{INaO}^{+}\right.$: 355.0; Found: 355.0. 


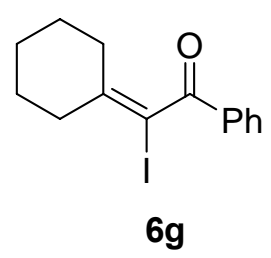

Compound $6 \mathrm{~g}$ was prepared in $83 \%$ yield according to the general procedure B. ${ }^{1} \mathrm{H}$ NMR $\left(400 \mathrm{MHz}, \mathrm{CDCl}_{3}\right) \delta 7.98(\mathrm{~d}, 2 \mathrm{H}, J=8 \mathrm{~Hz}), 7.50(\mathrm{t}, 1 \mathrm{H}, J=7.6 \mathrm{~Hz}), 7.48(\mathrm{t}, 2 \mathrm{H}, J=7.6$ $\mathrm{Hz}), 2.55(\mathrm{t}, 2 \mathrm{H}, J=6 \mathrm{~Hz}), 2.22(\mathrm{t}, 2 \mathrm{H}, J=6 \mathrm{~Hz}), 1.75-1.69(\mathrm{~m}, 2 \mathrm{H}), 1.60-1.54(\mathrm{~m}, 2 \mathrm{H})$, 1.47-1.42 (m, 2H); ${ }^{13} \mathrm{C}$ NMR (125 MHz, $\left.\mathrm{CDCl}_{3}\right) \delta 193.1,149.6,134.0,133.7,130.0$, 128.7, 87.7, 38.9, 33.2, 27.5, 27.4, 25.8; IR (neat): 3308, 3061, 2932, 2854, 2668, 2201, 1966, 1908, 1817, 1777, 1664, 1632, 1596, 1579, 1448, 1311, 1221, 1173, 1022, 982, 824; MS (ES ${ }^{+}$) Calculated for $\left[\mathrm{C}_{14} \mathrm{H}_{15} \mathrm{INaO}\right]^{+}$: 349.0; Found: 349.0. 

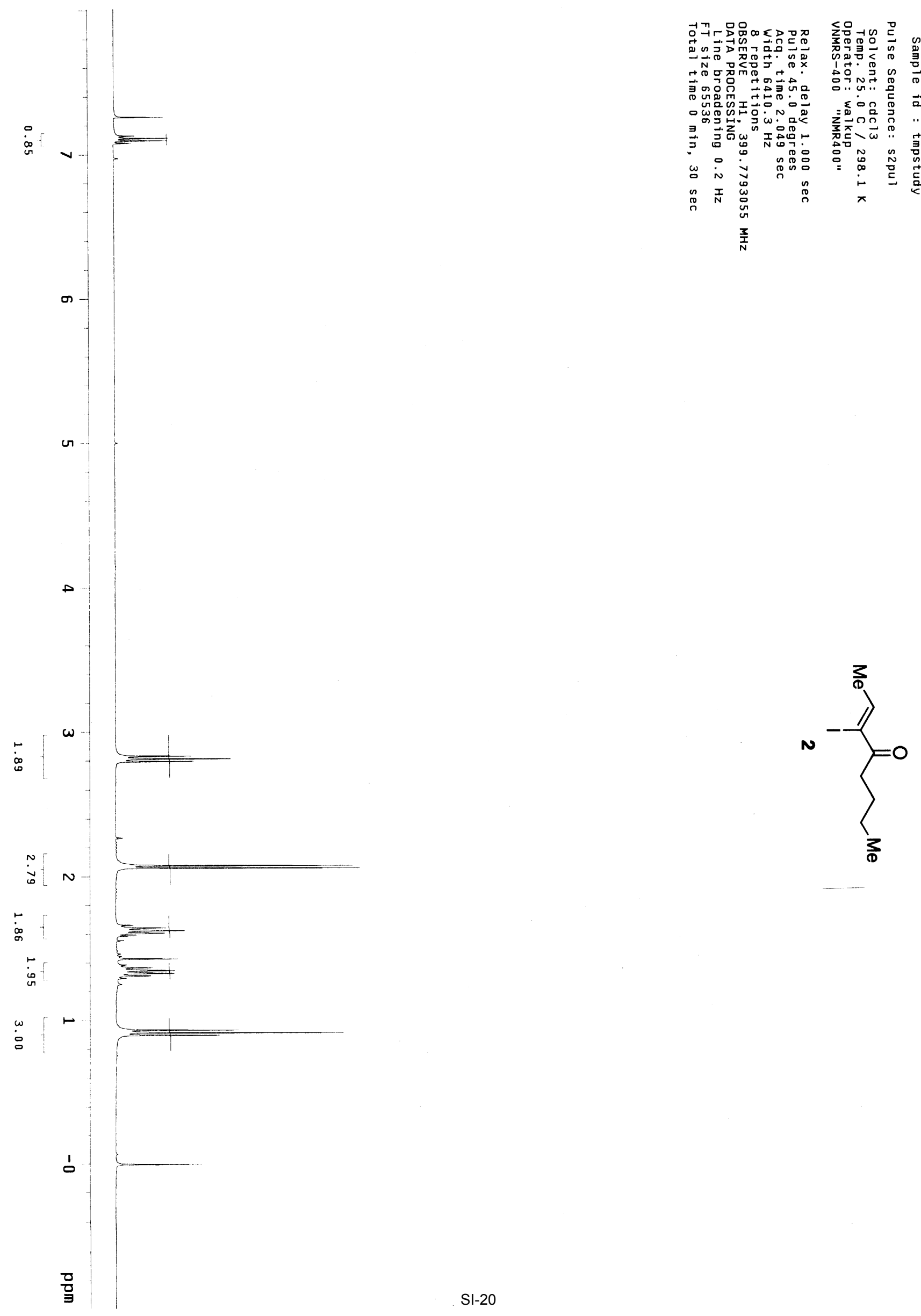

艊品

(1).

음을

-

Э

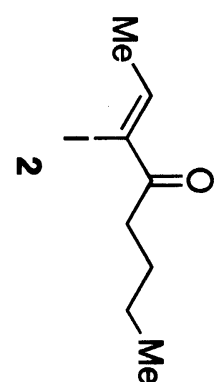



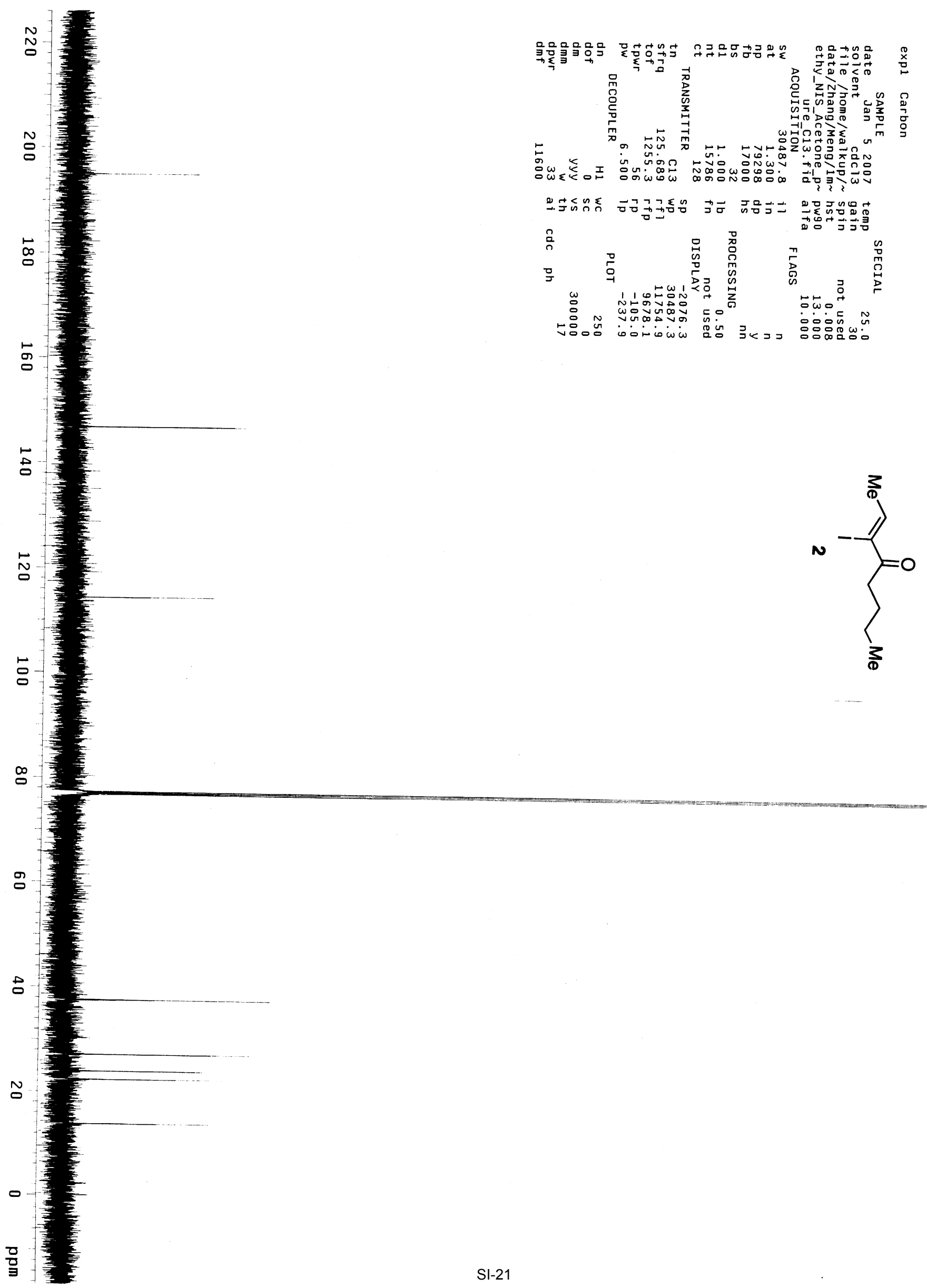


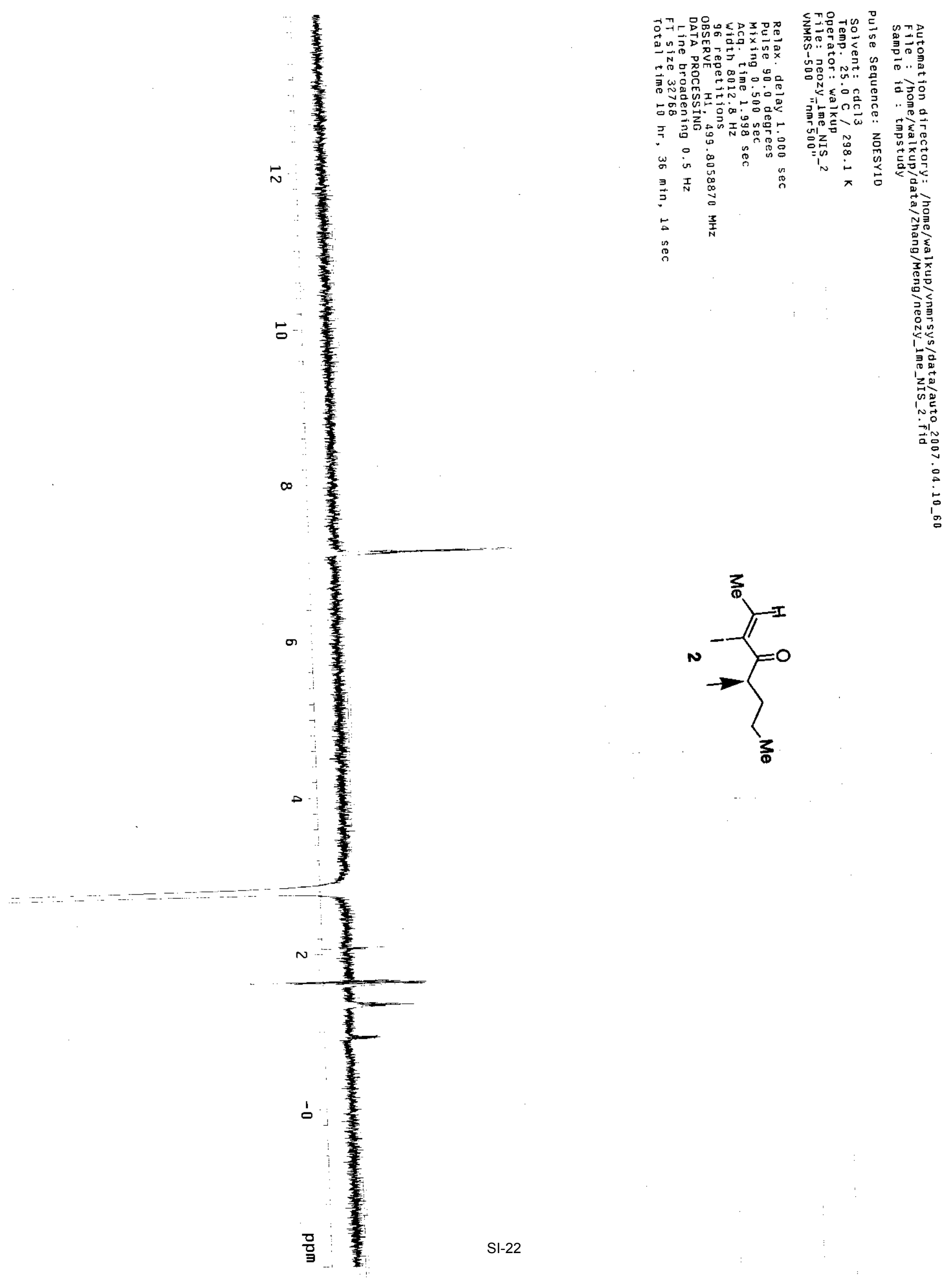




$$
b^{*}
$$




$$
\text { it }
$$




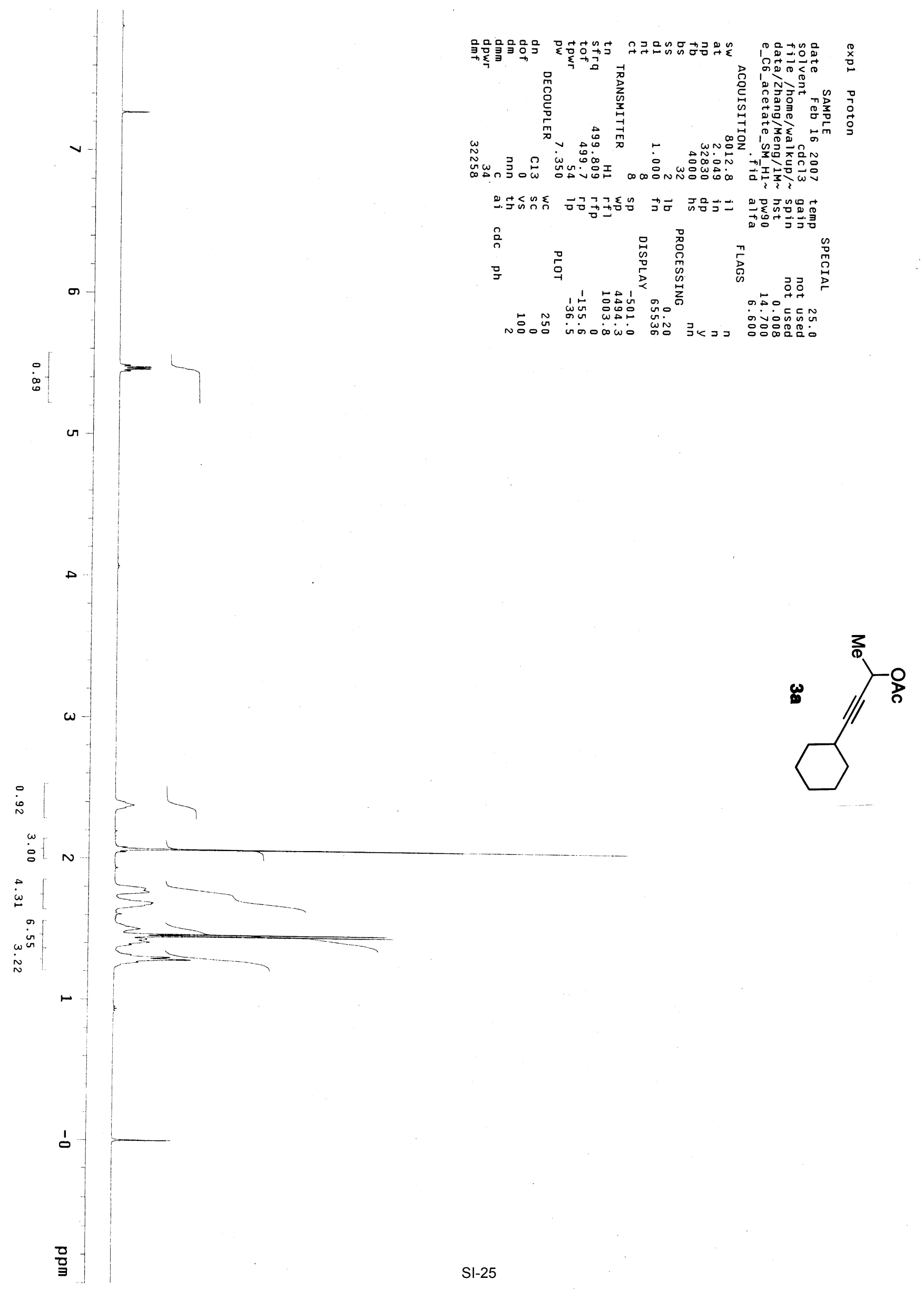




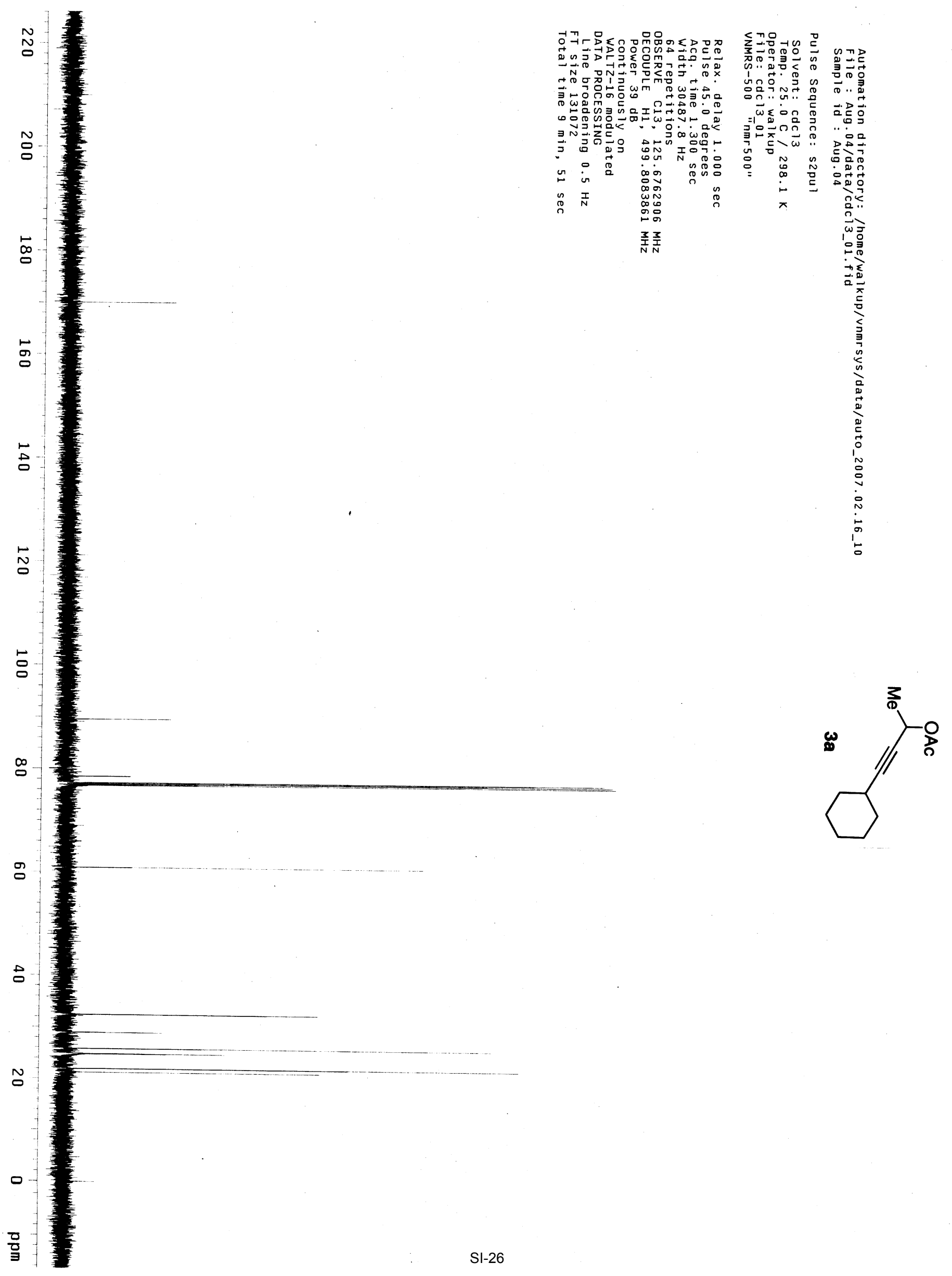




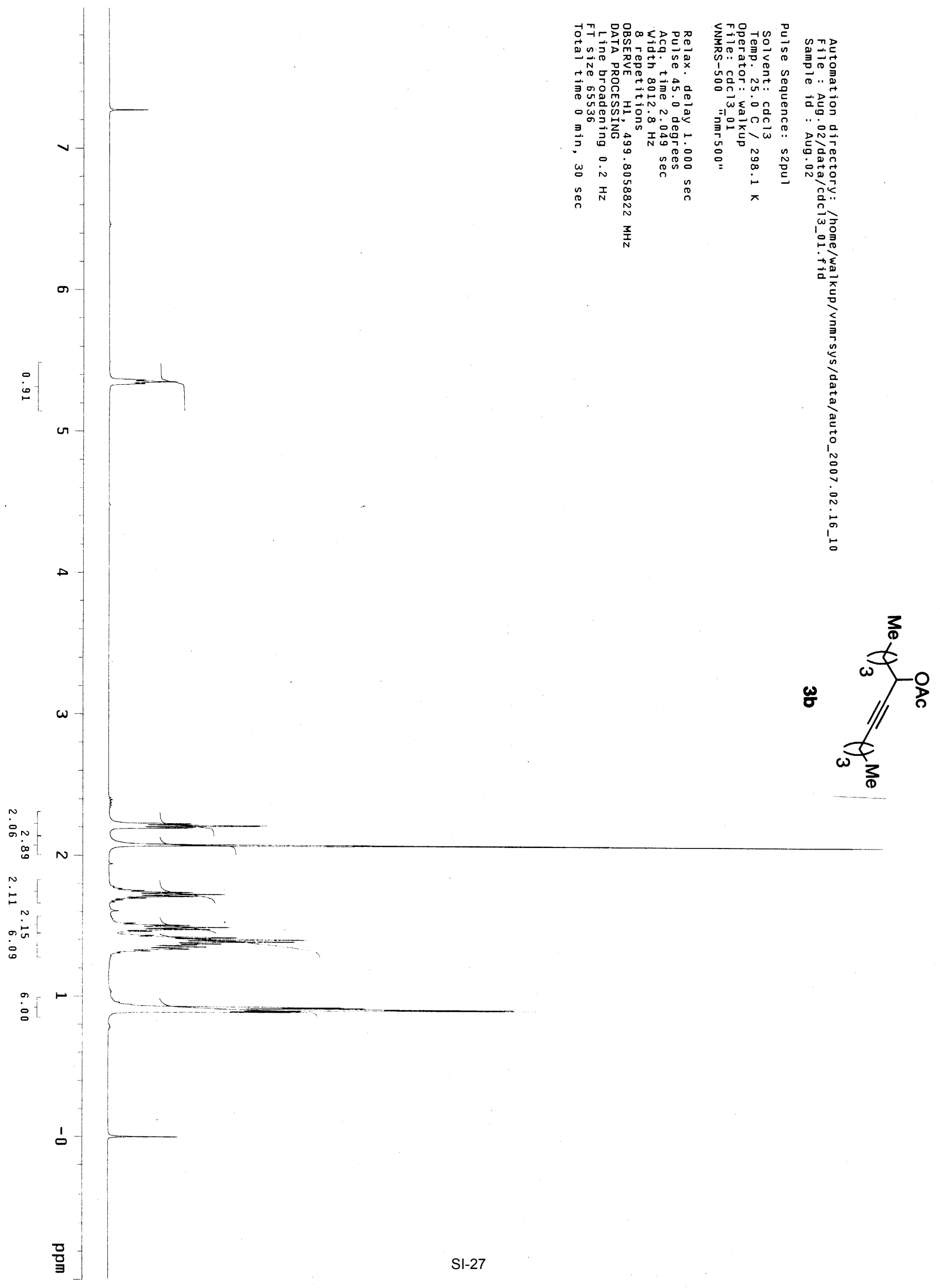



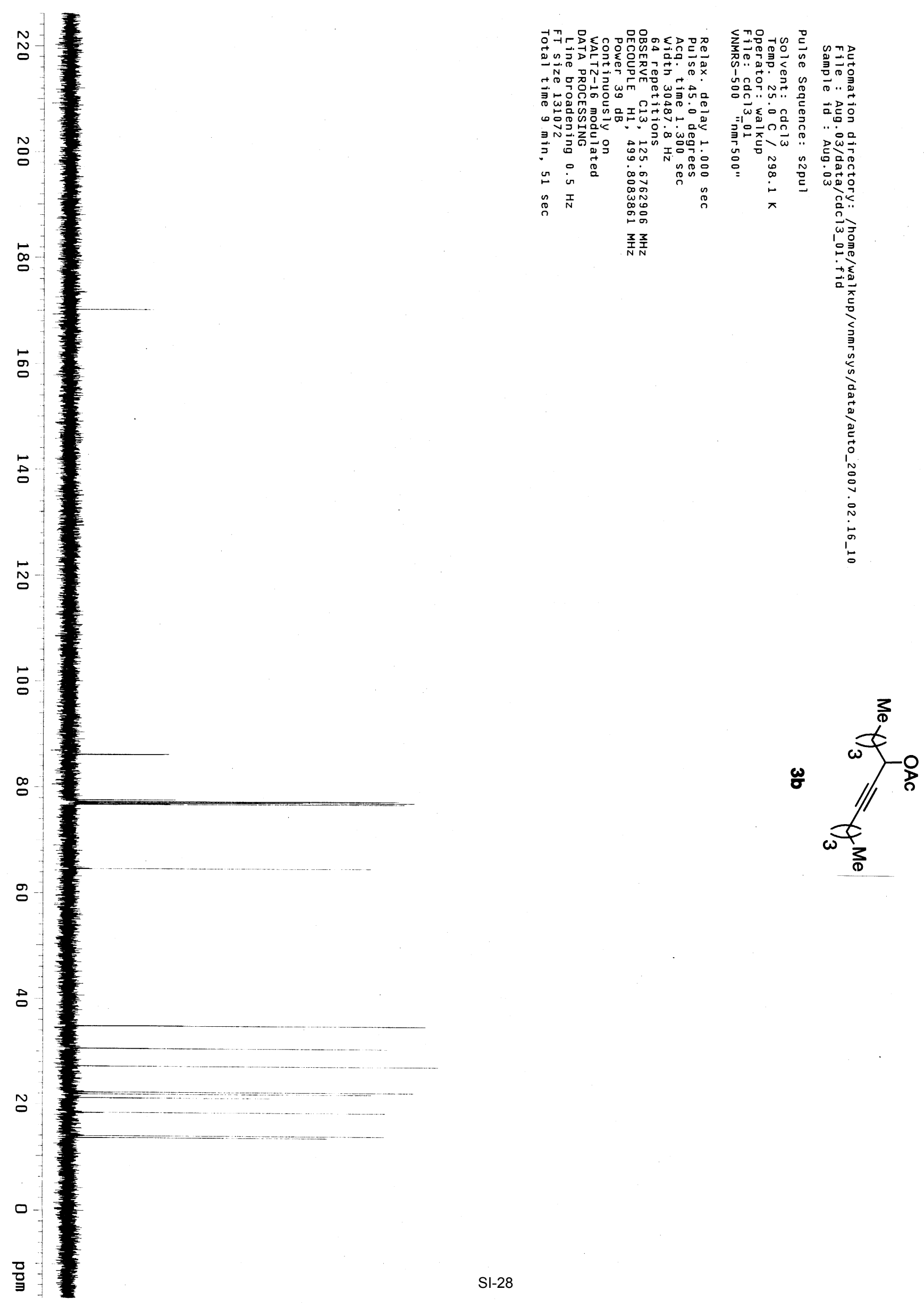


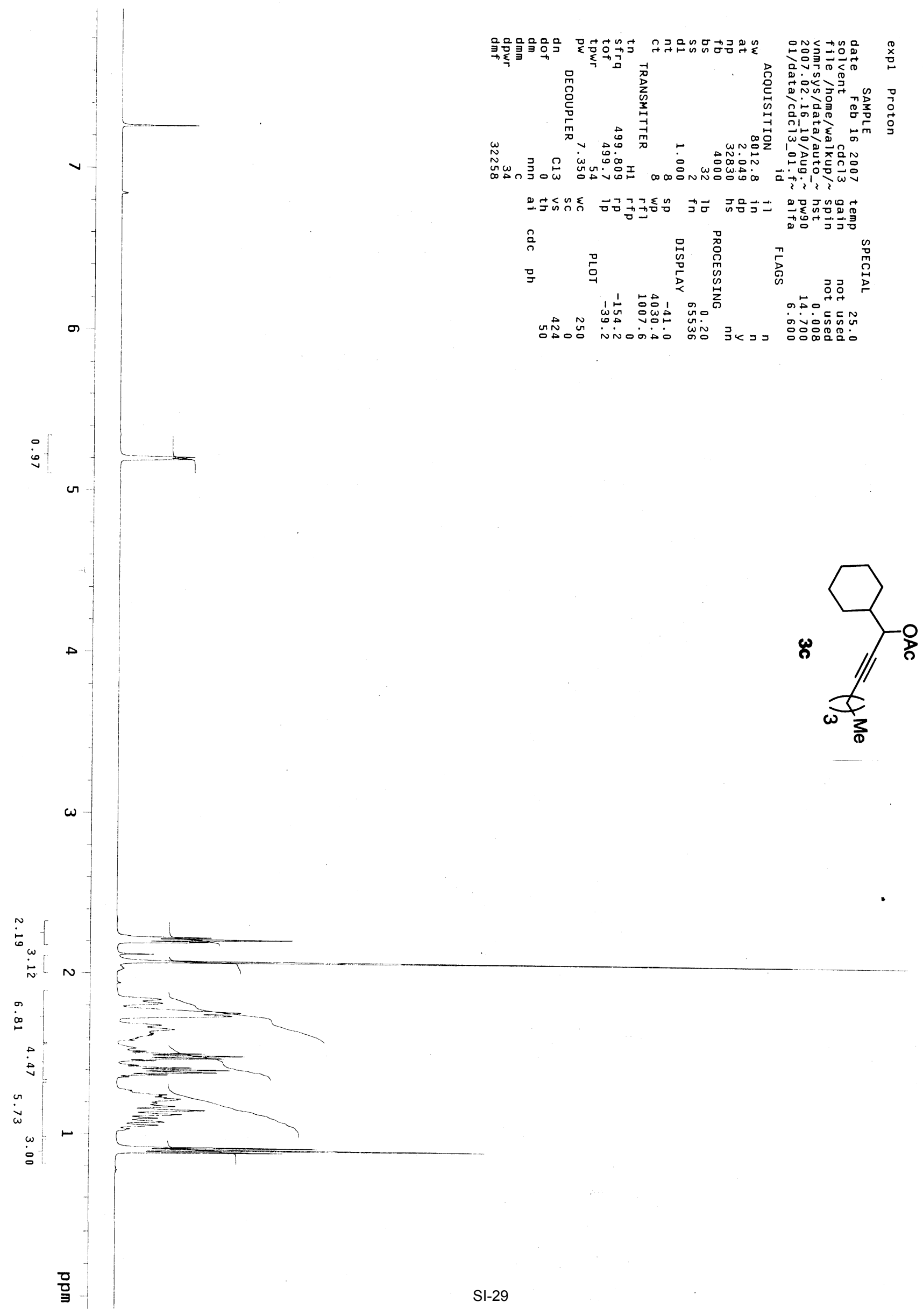



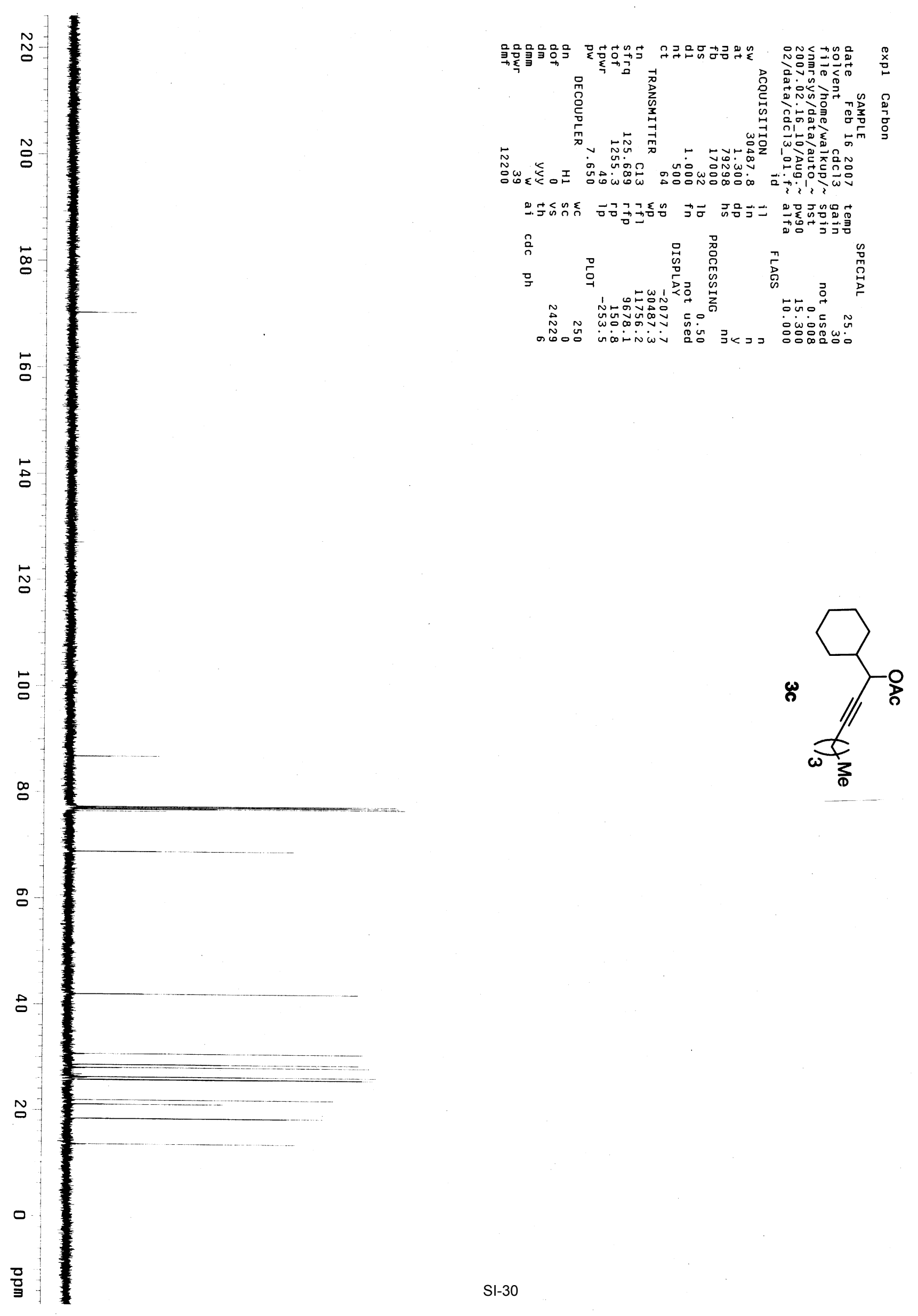

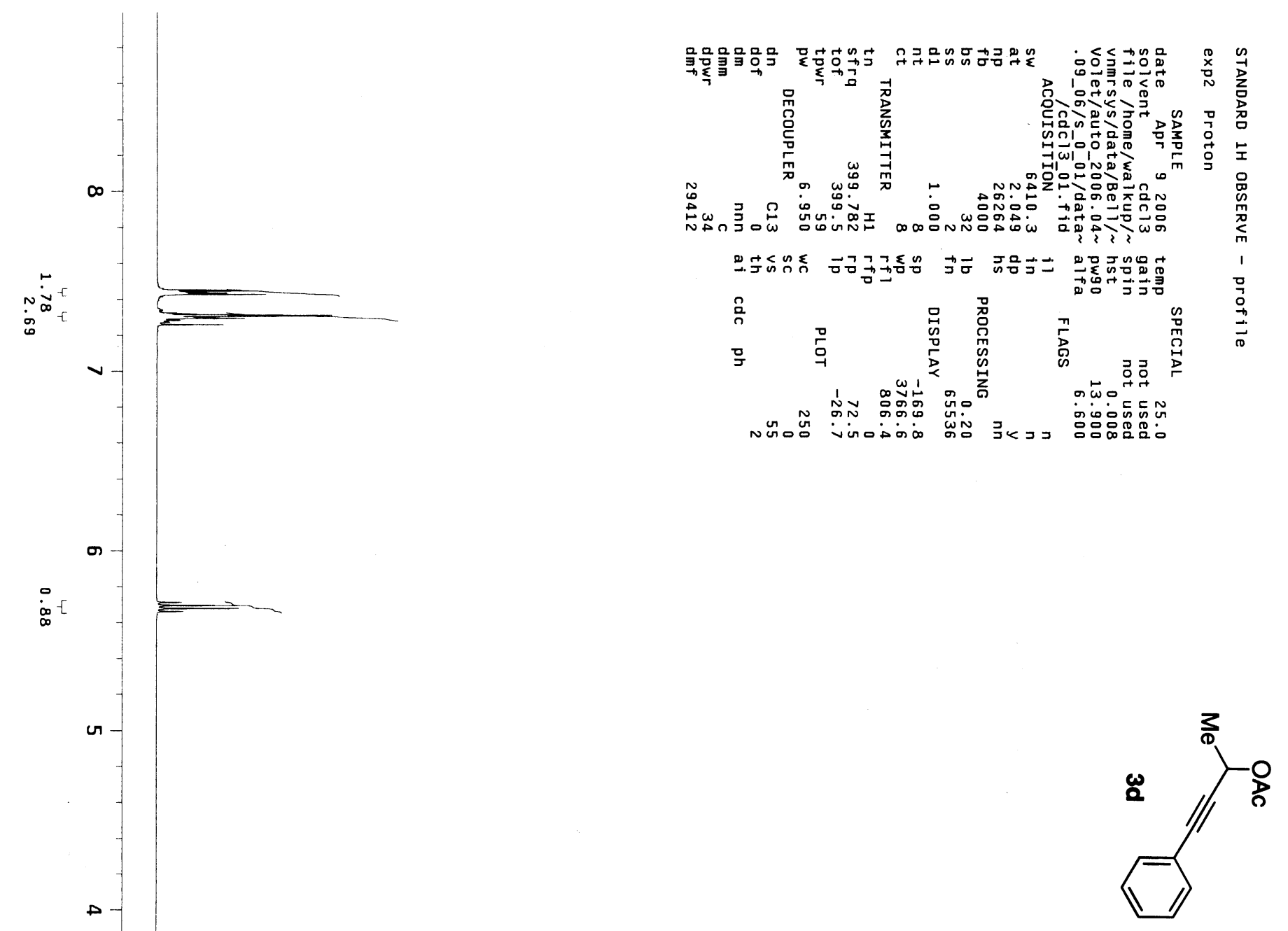


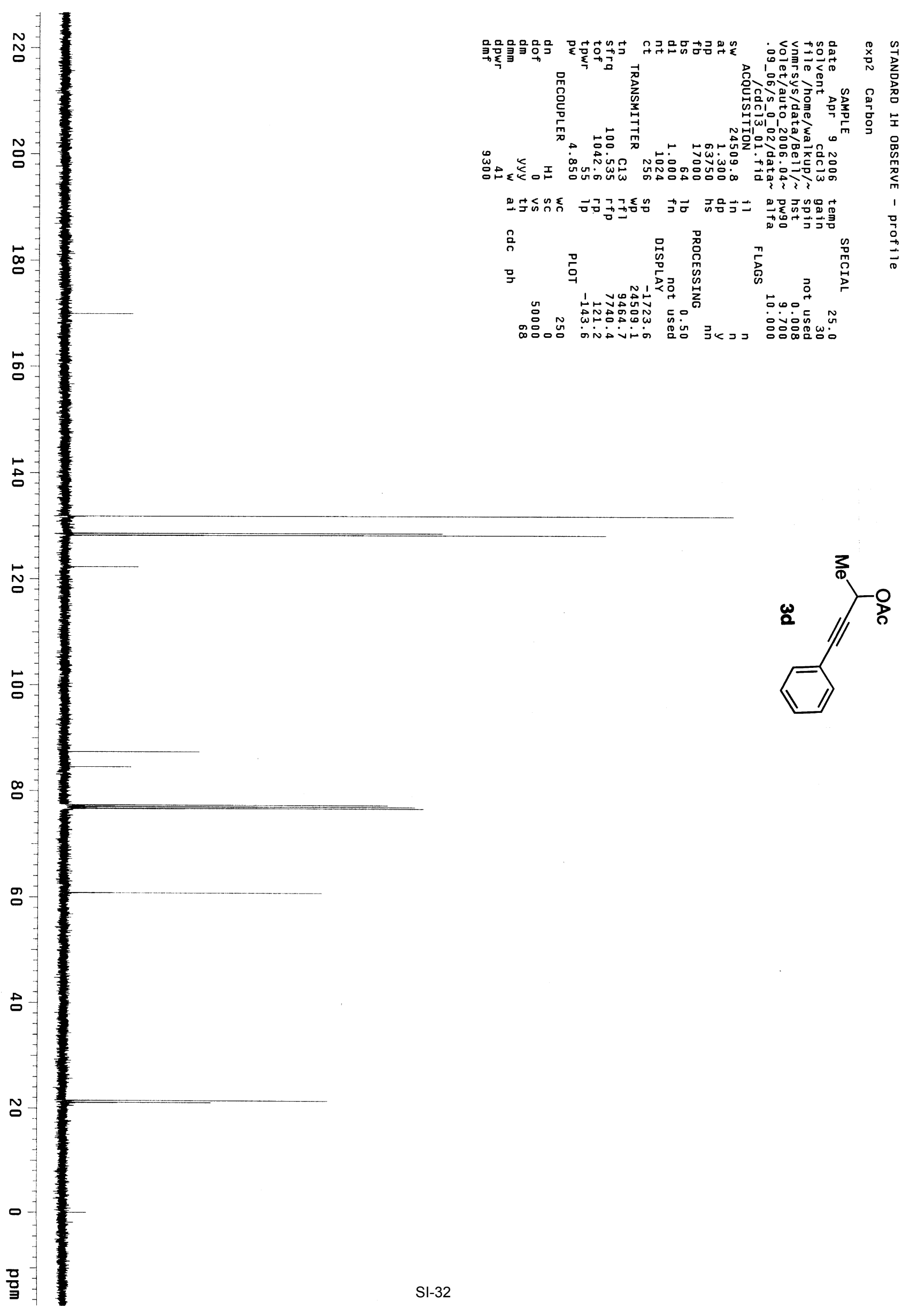




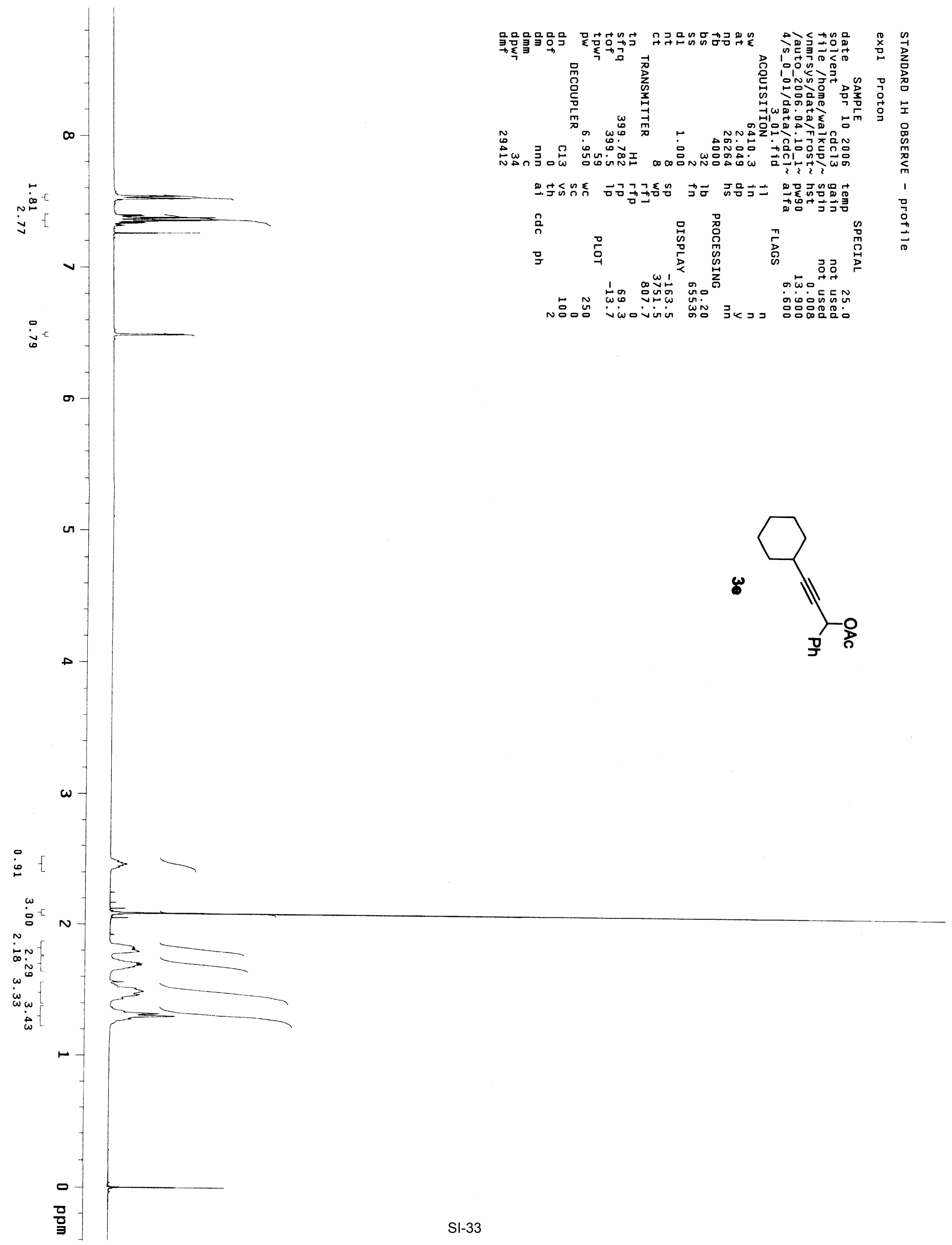



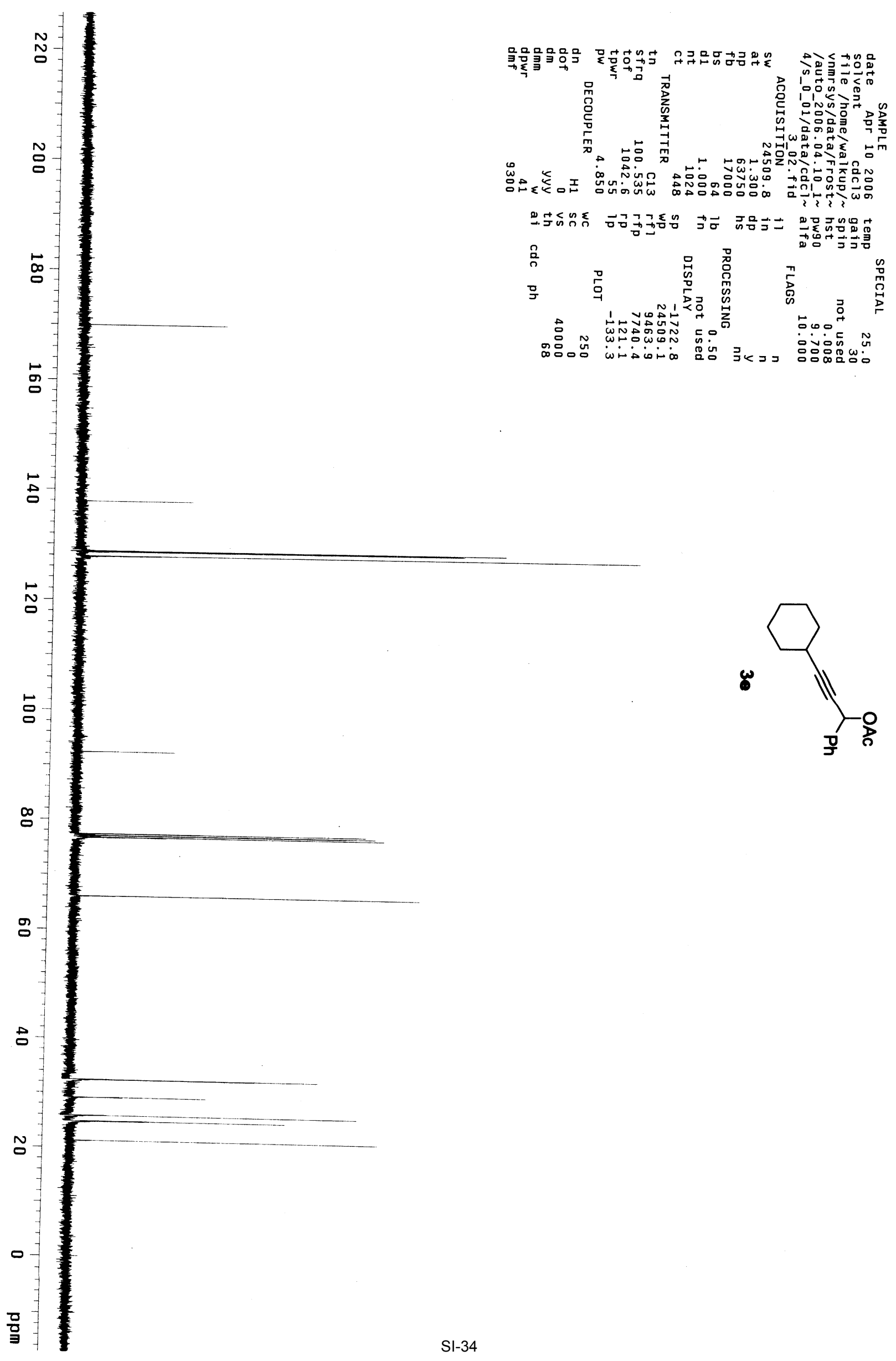


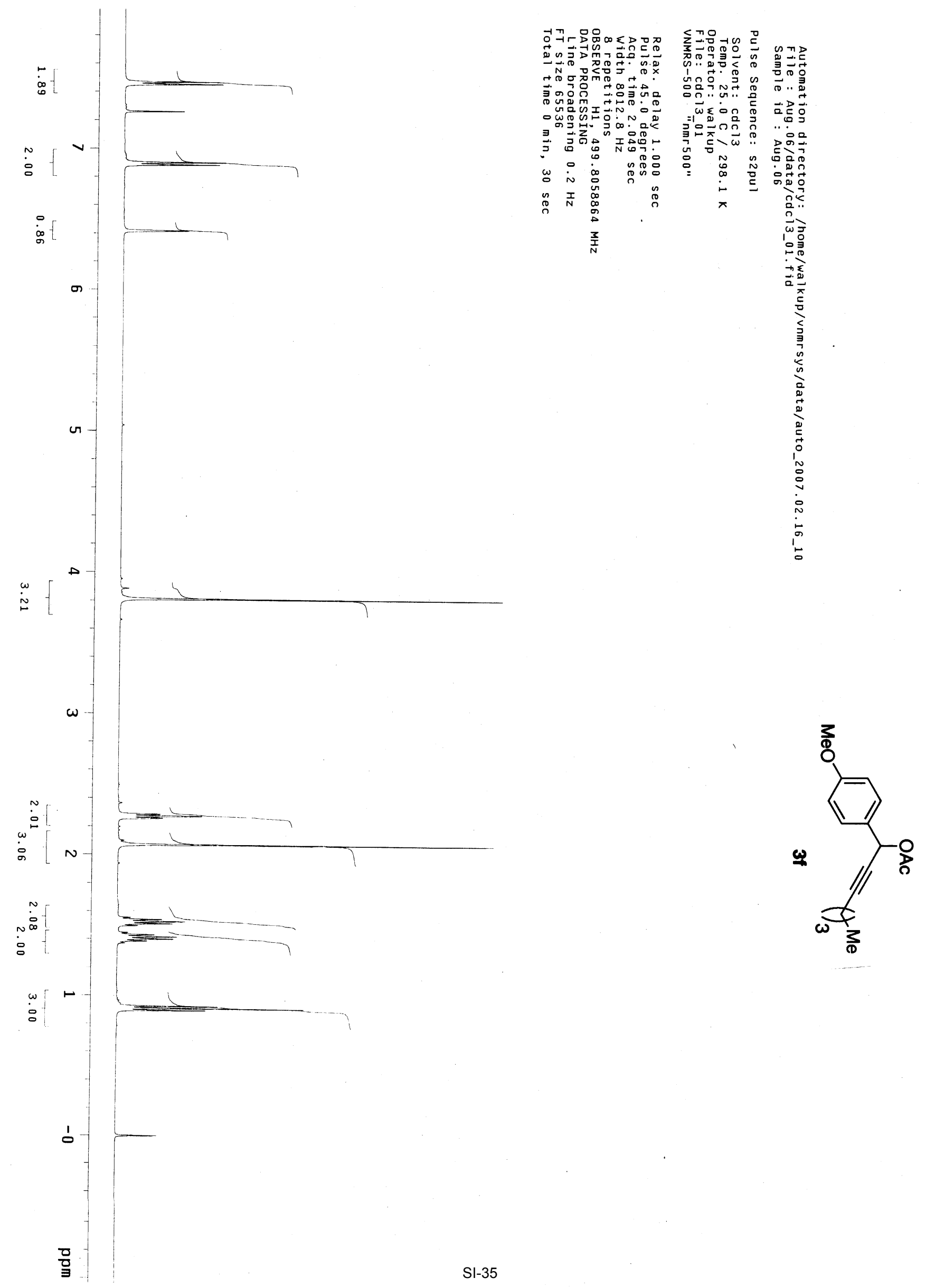



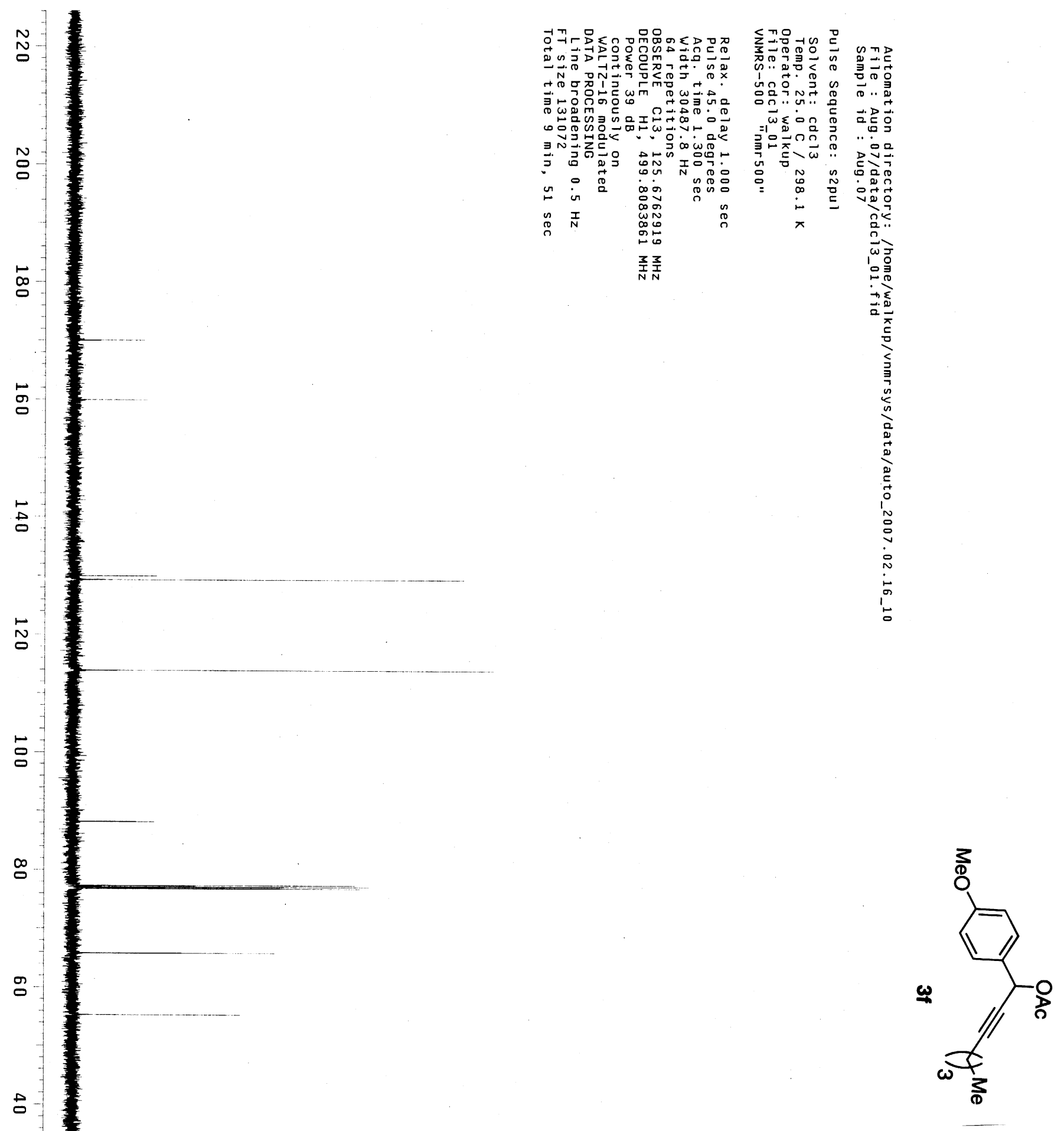

SI-36 


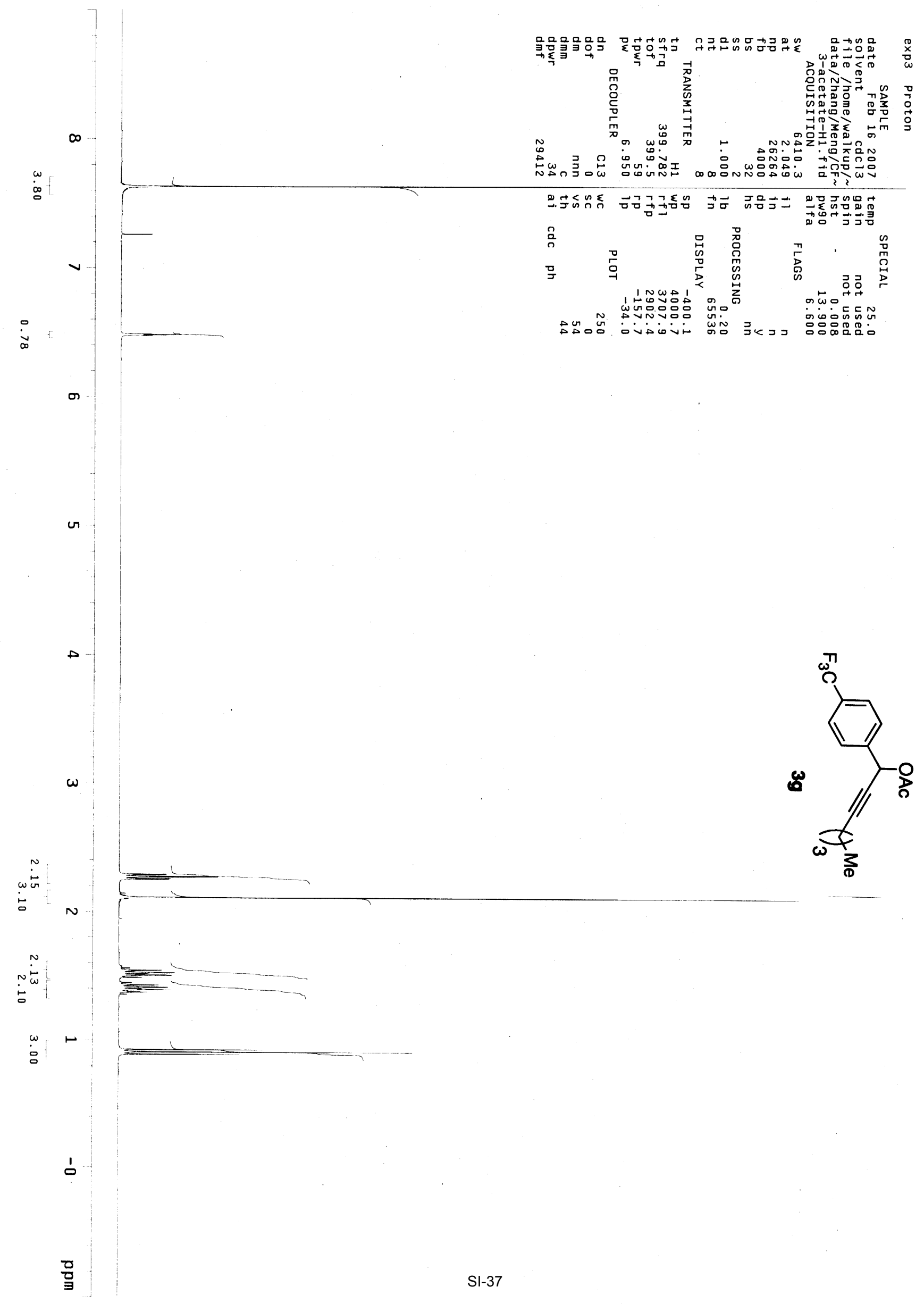




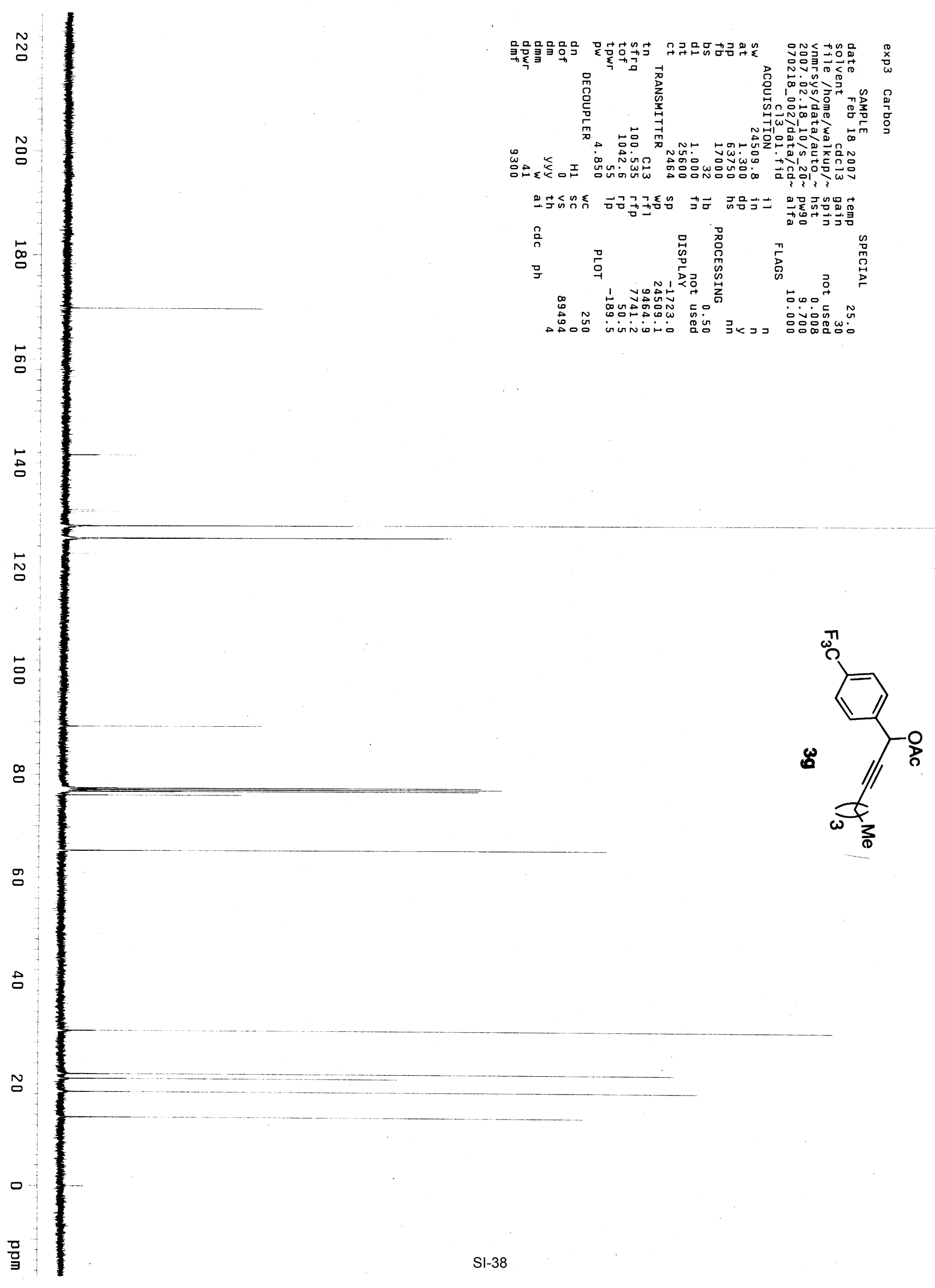




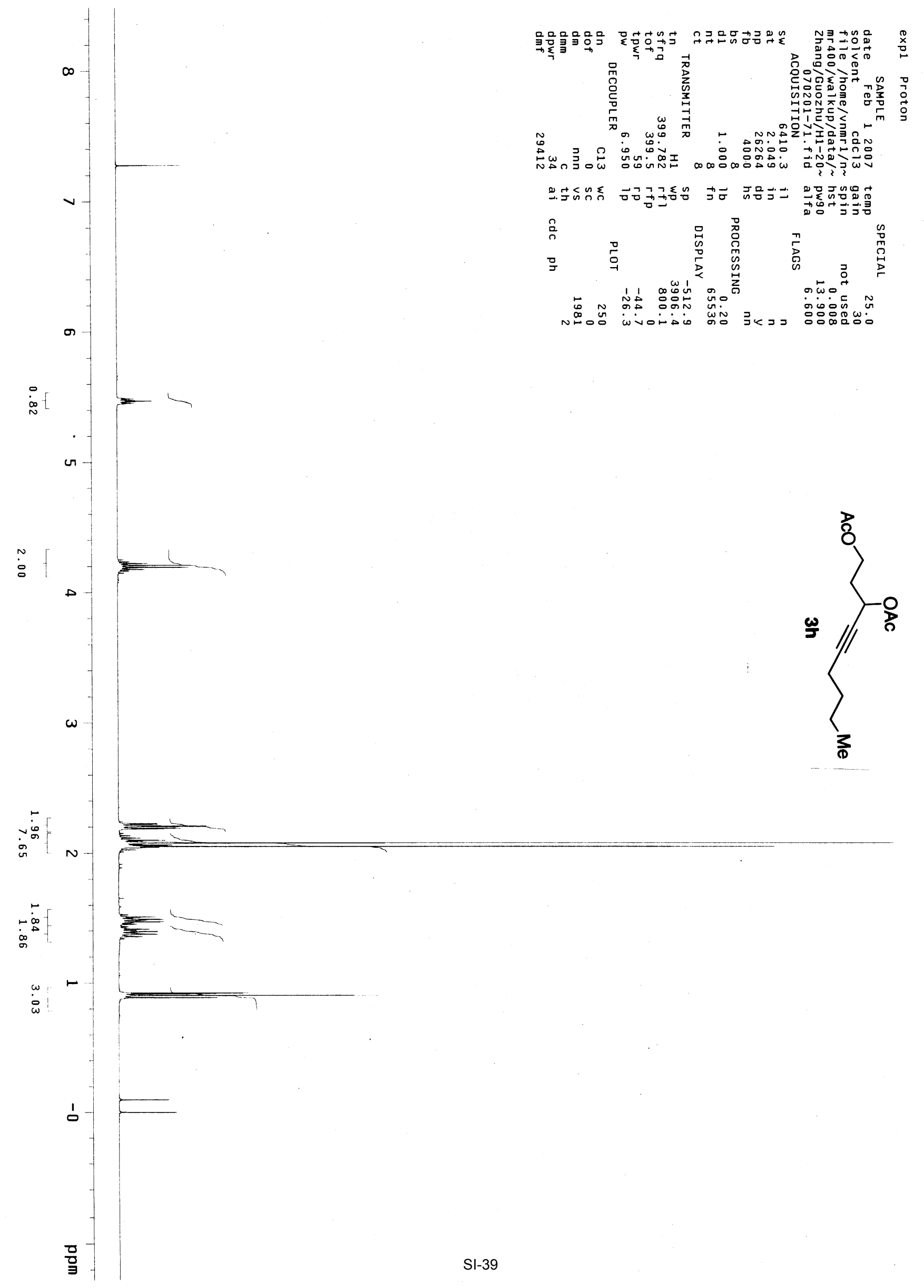



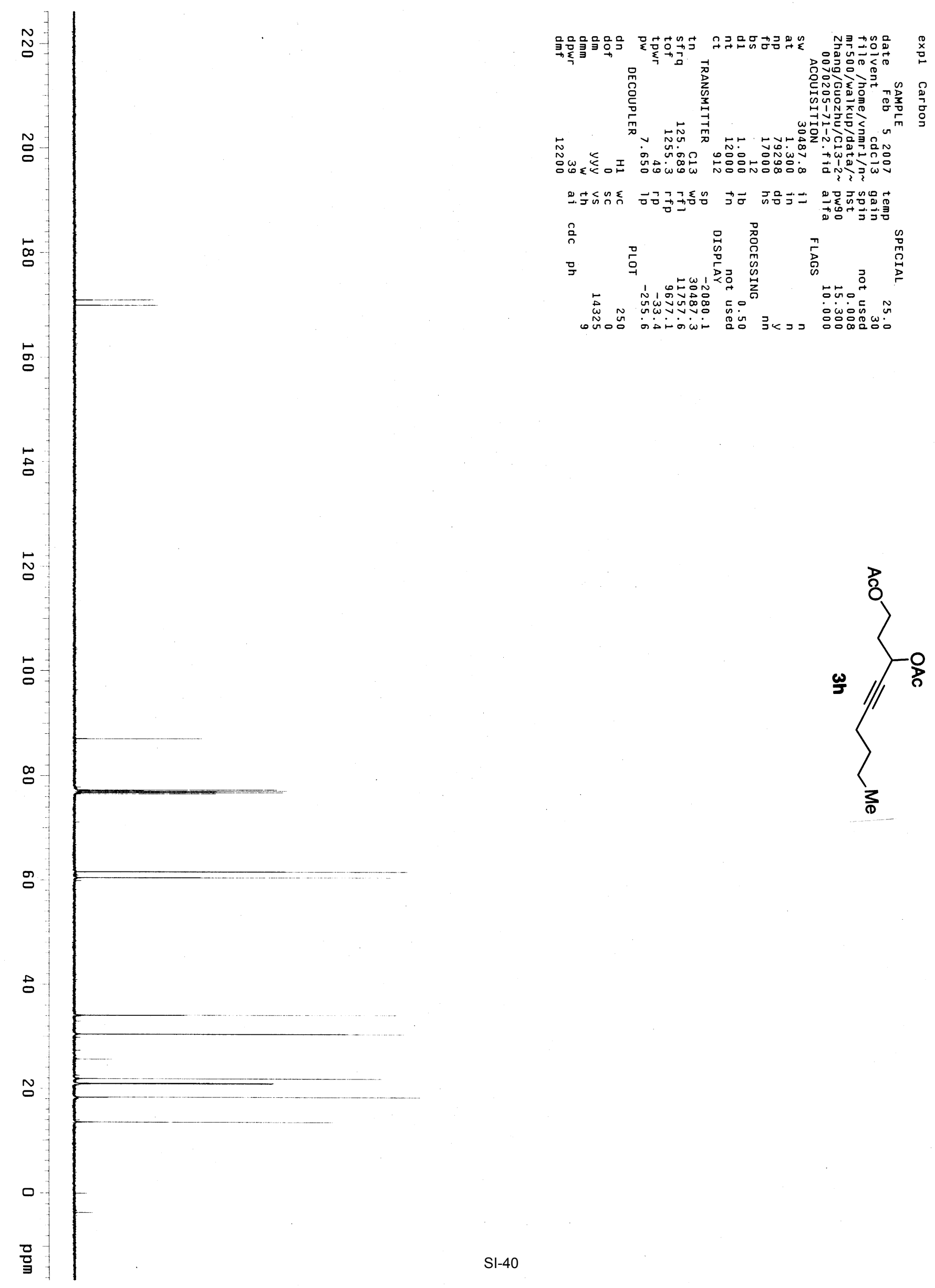


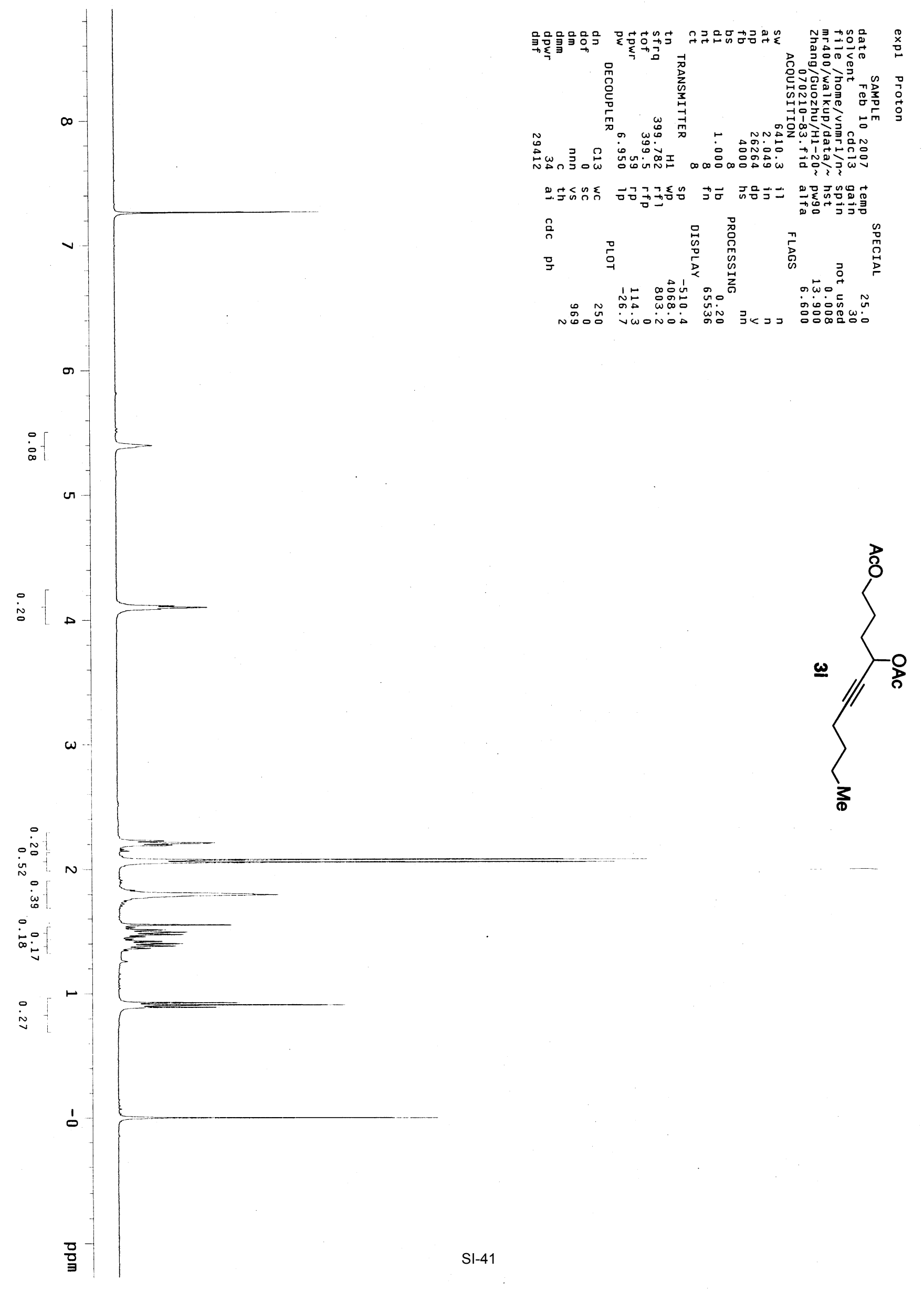




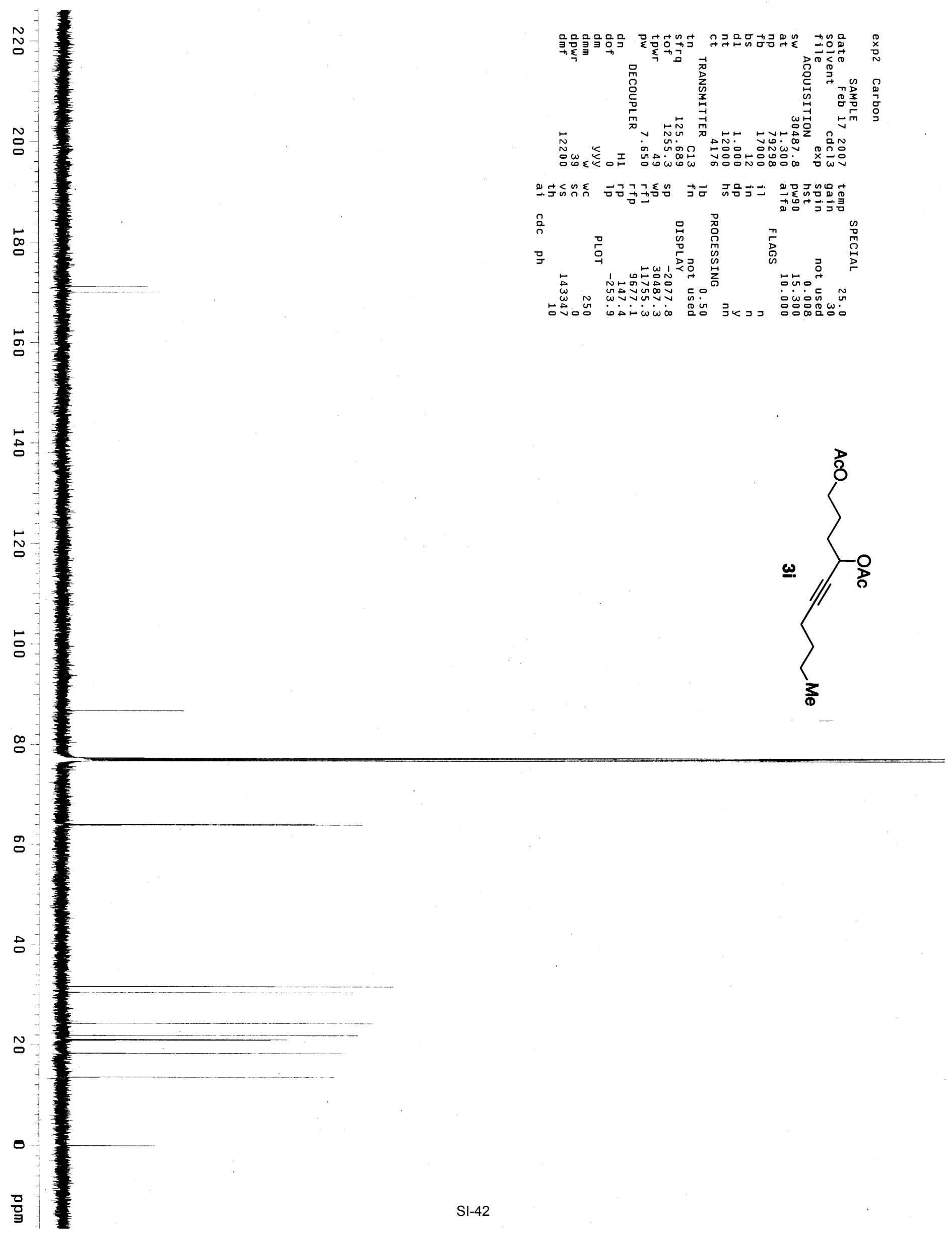



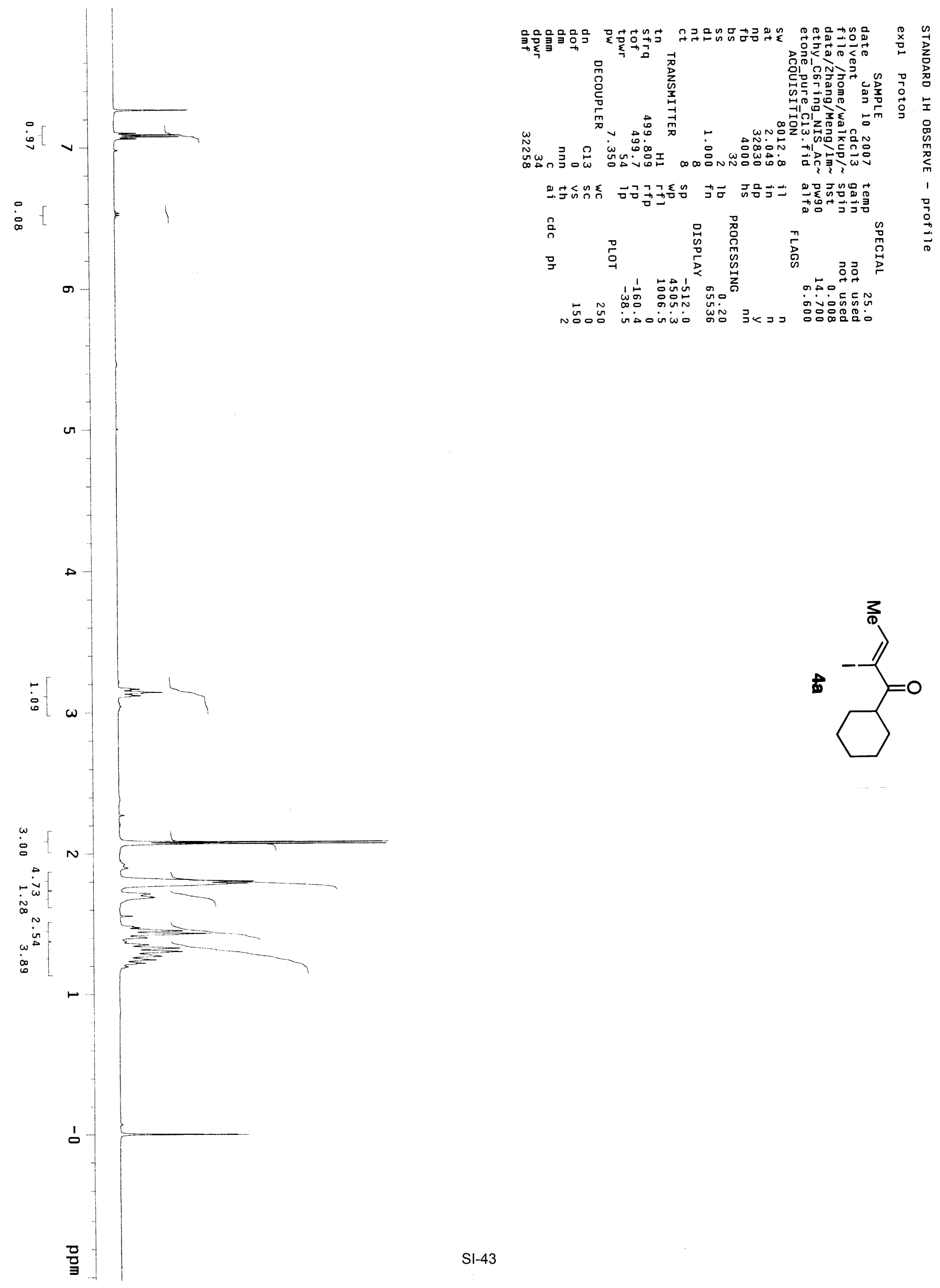

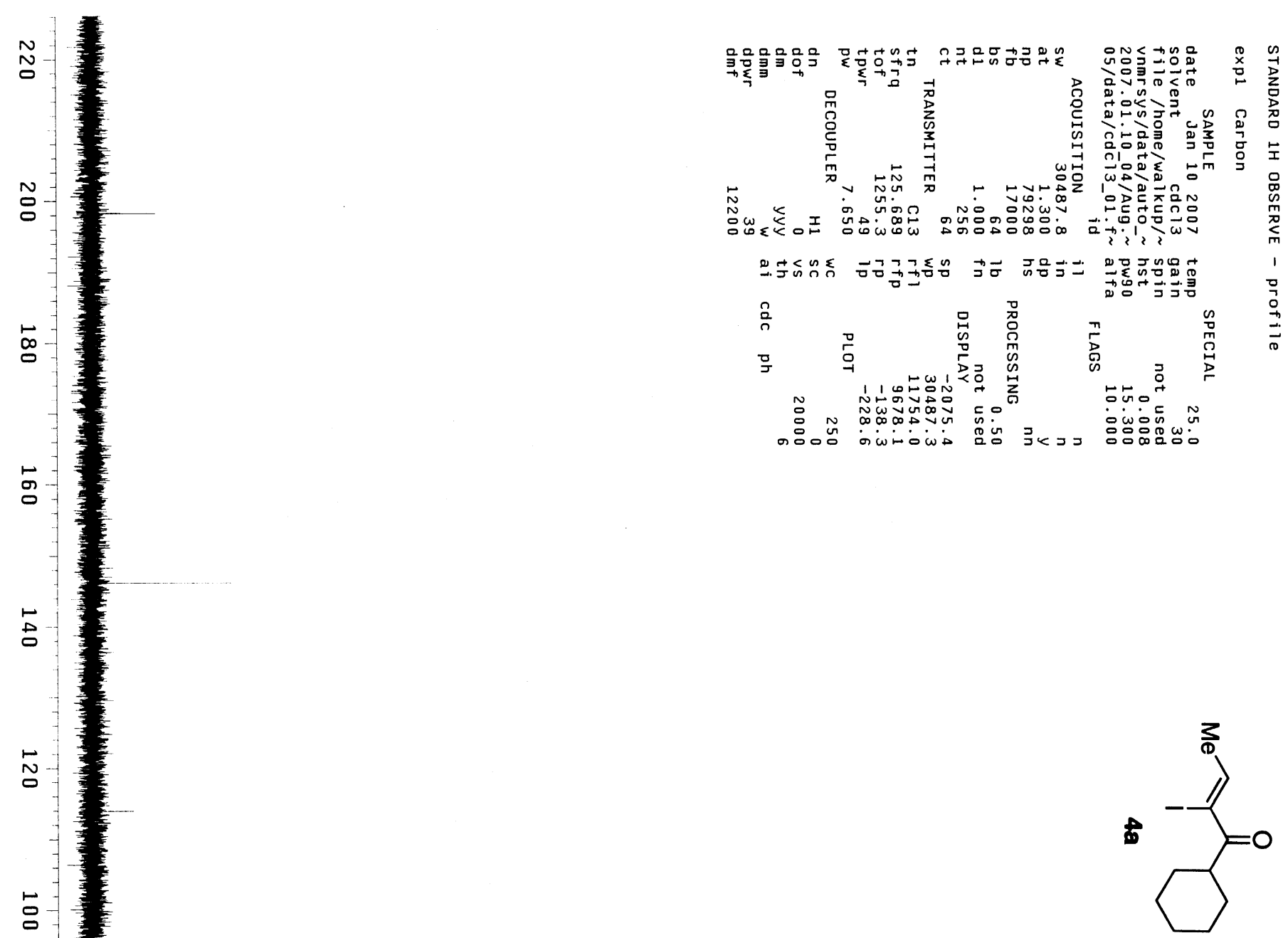

○.

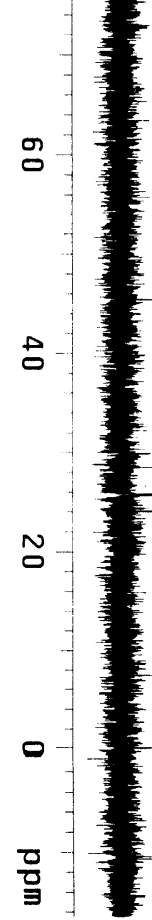

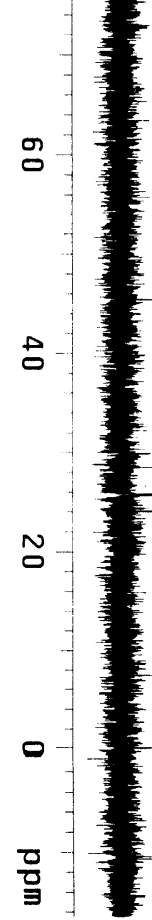

品

$\stackrel{5}{0}$

เ

-

7

正 


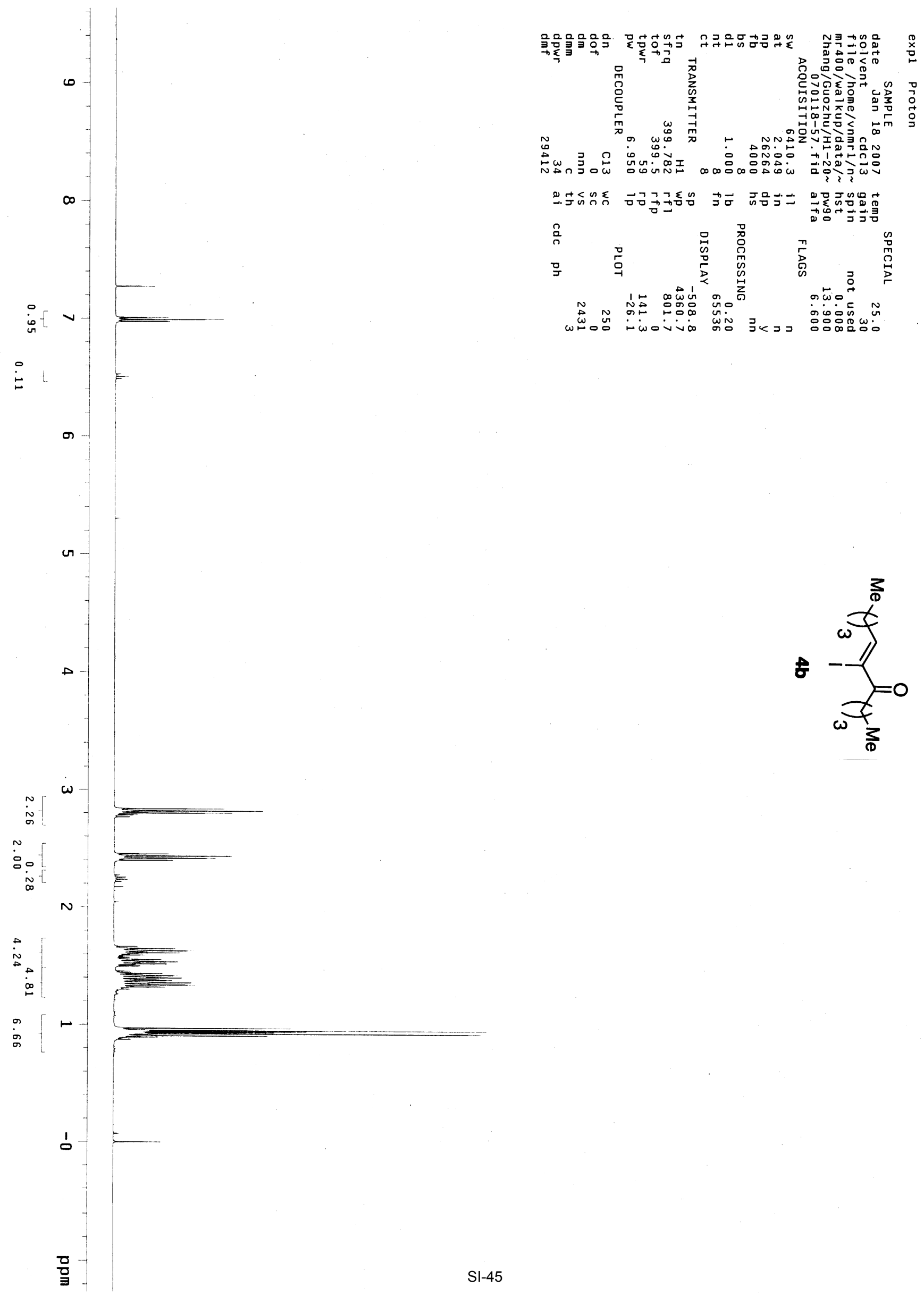



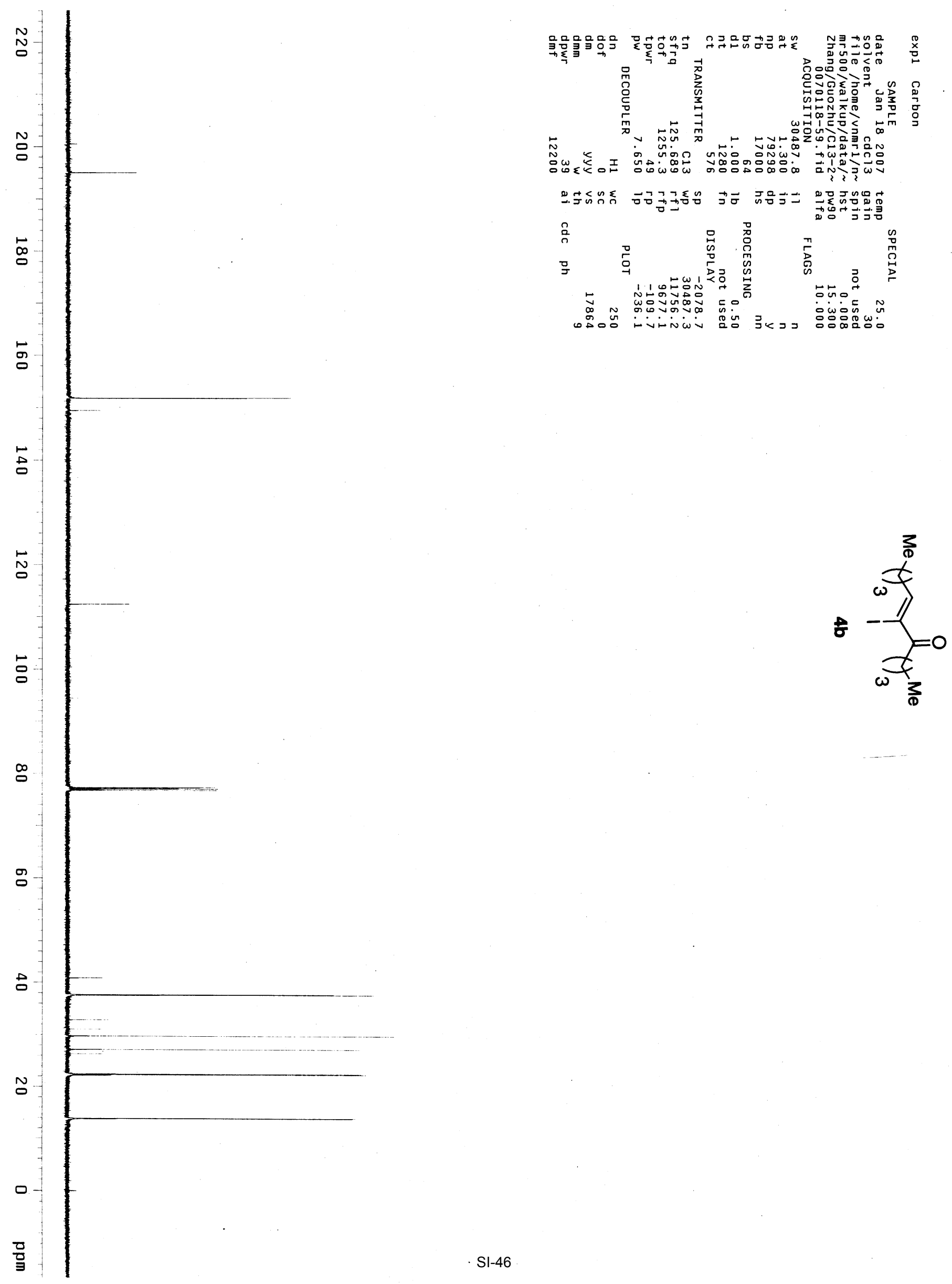


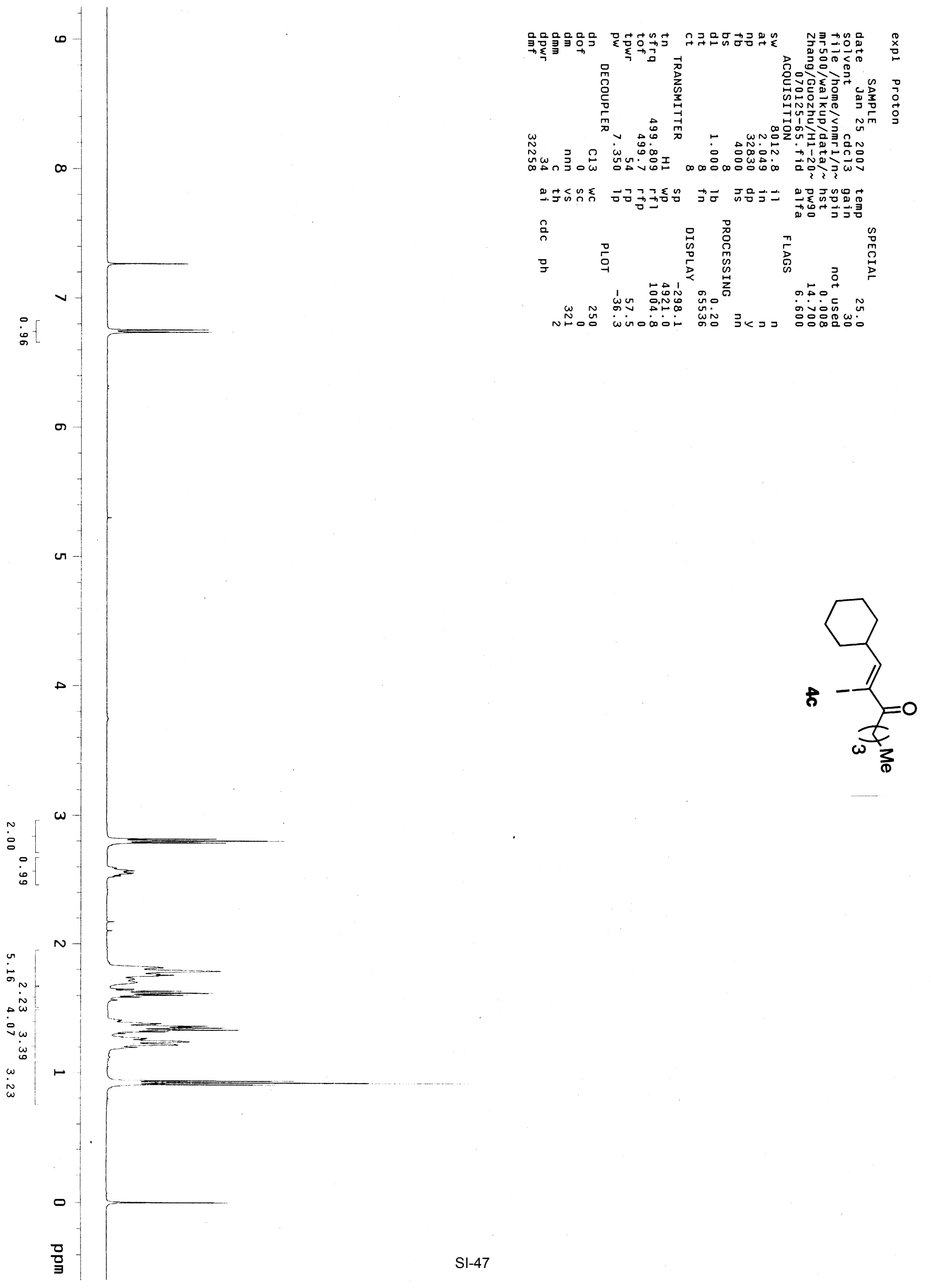



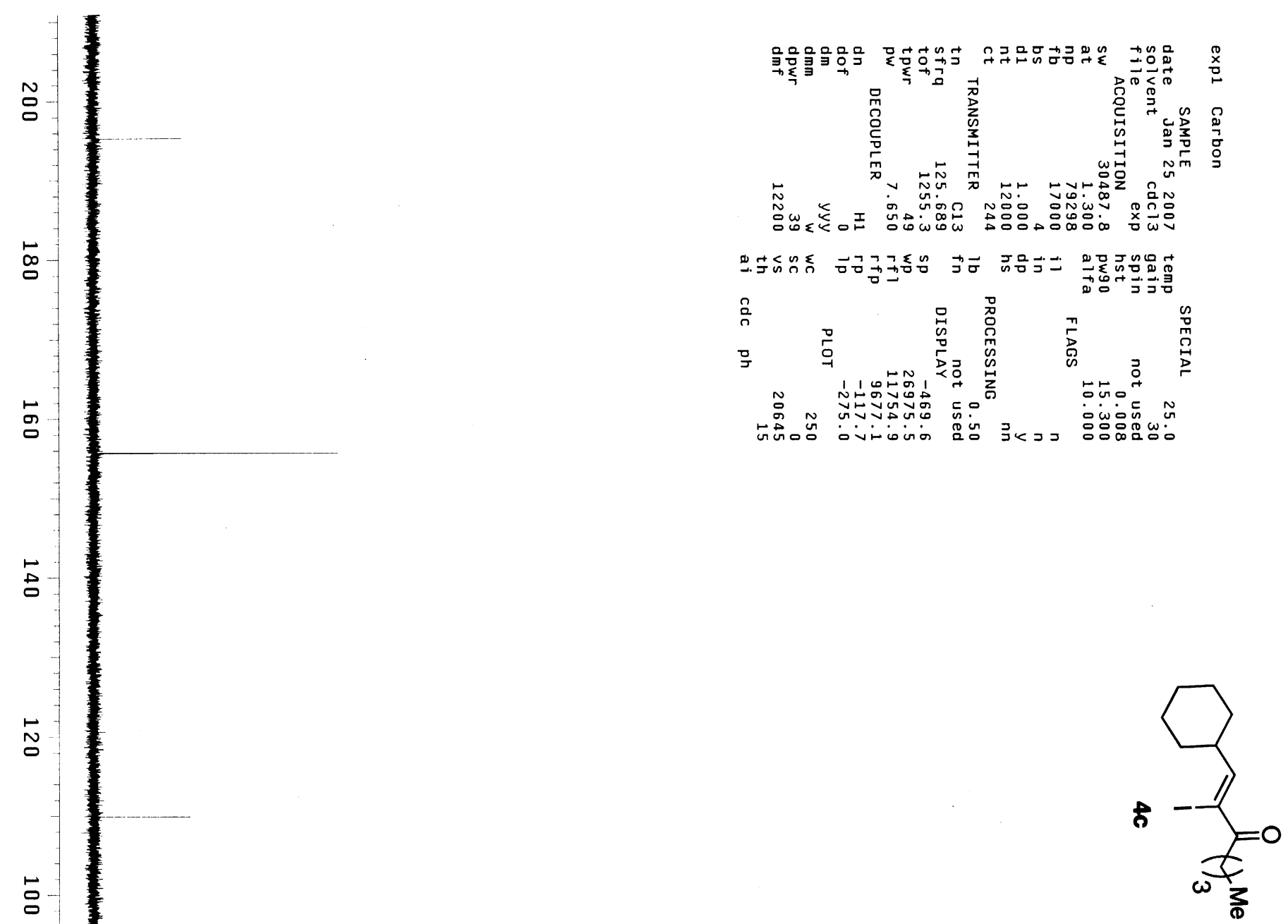


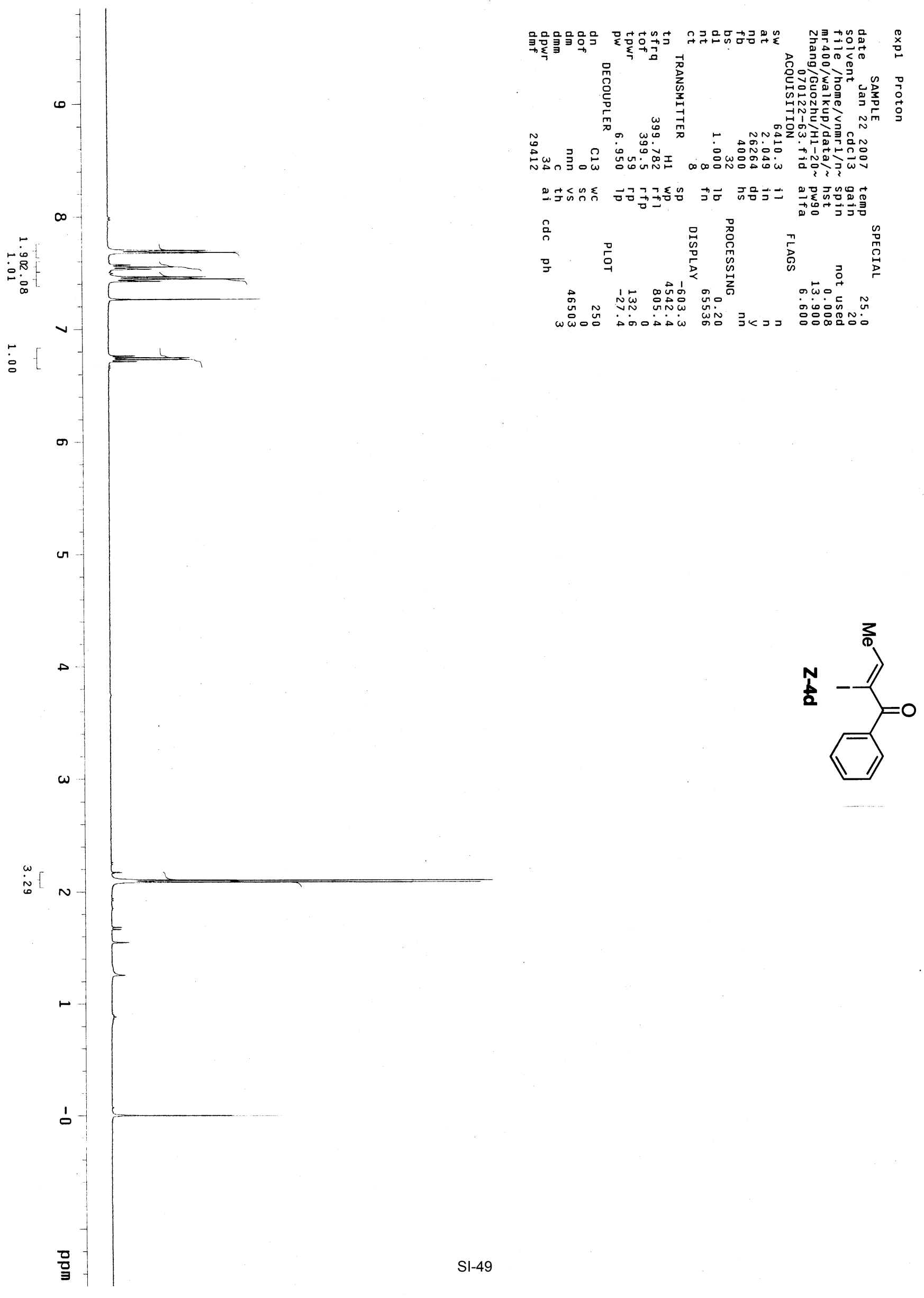




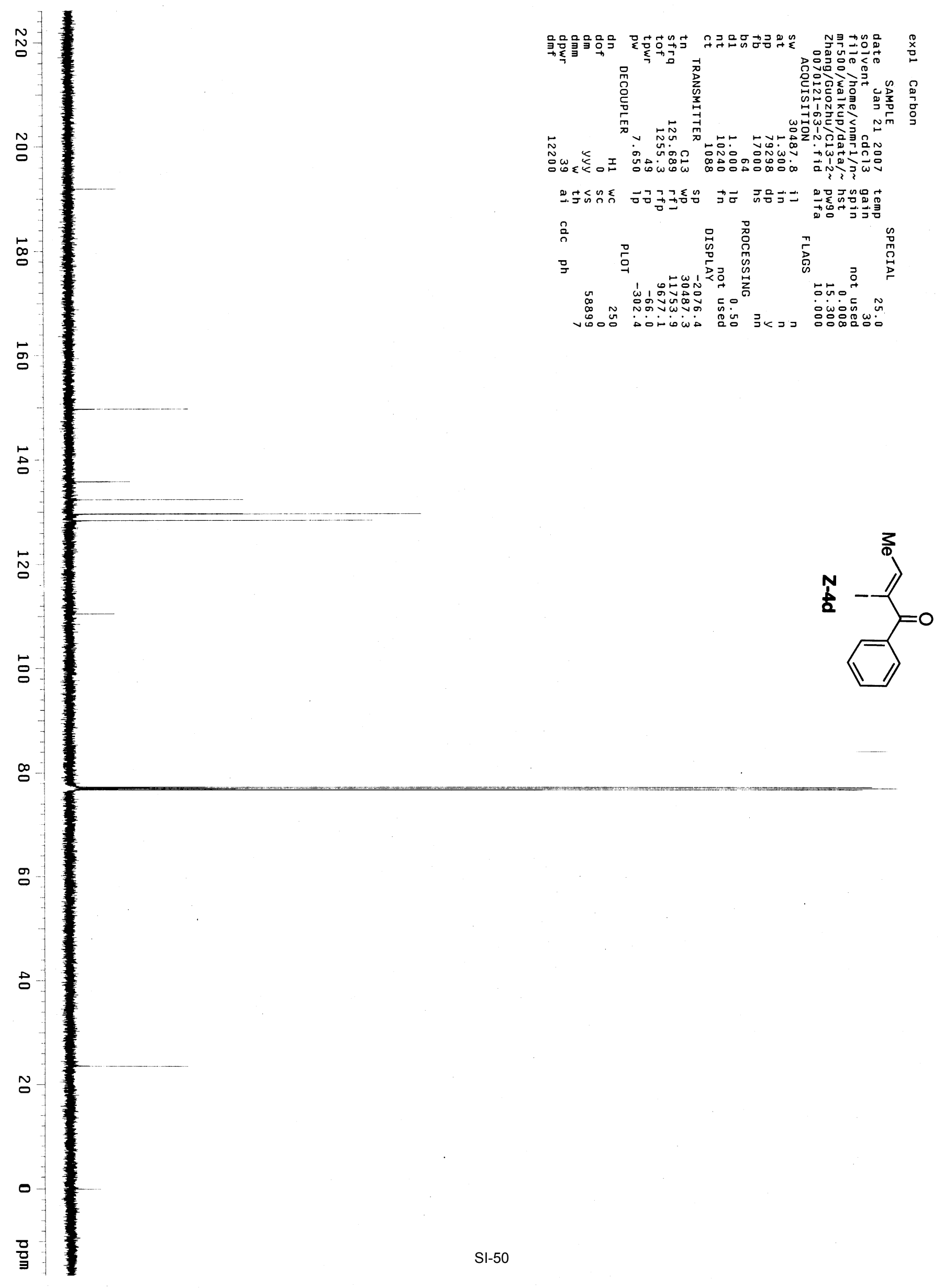



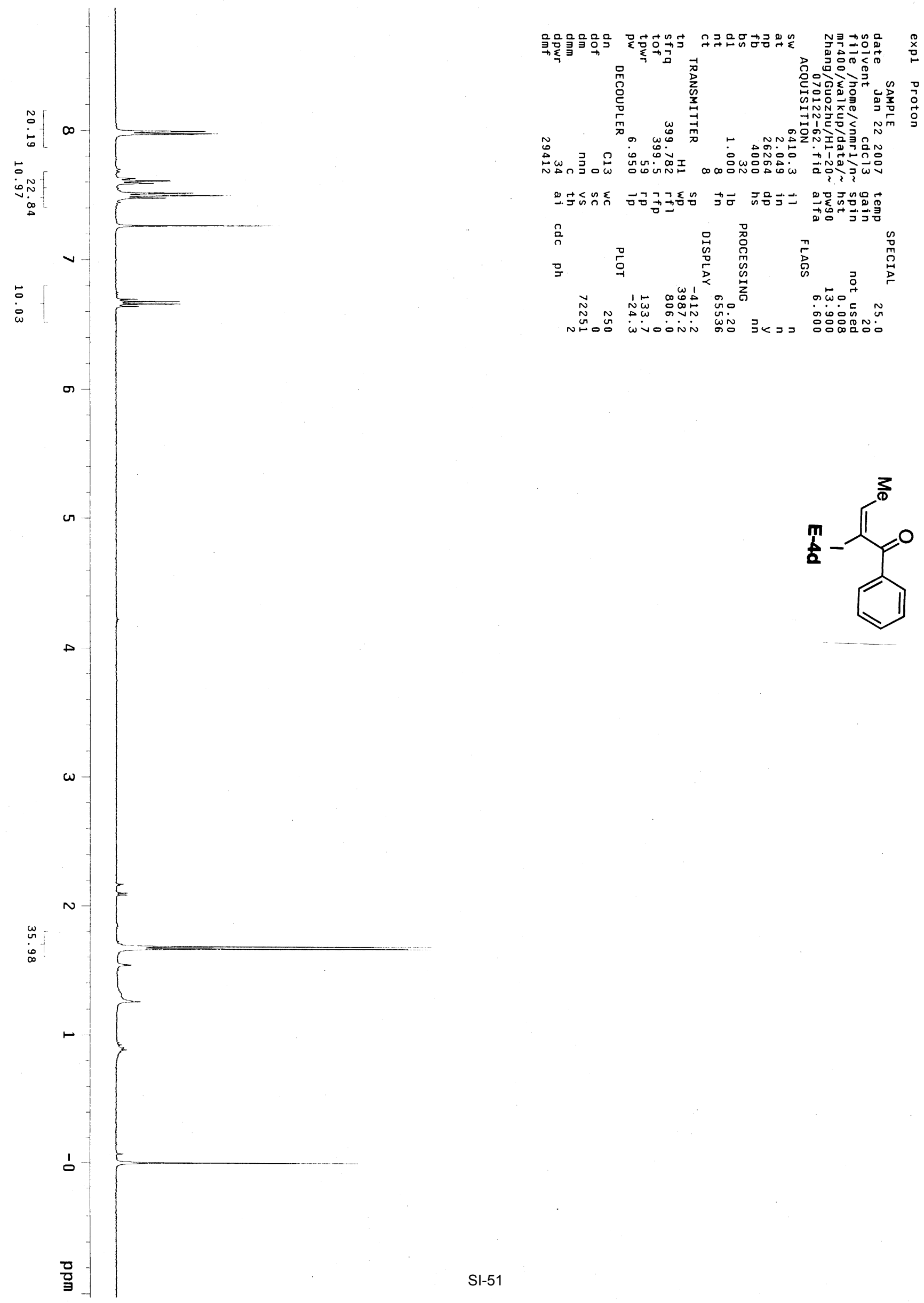

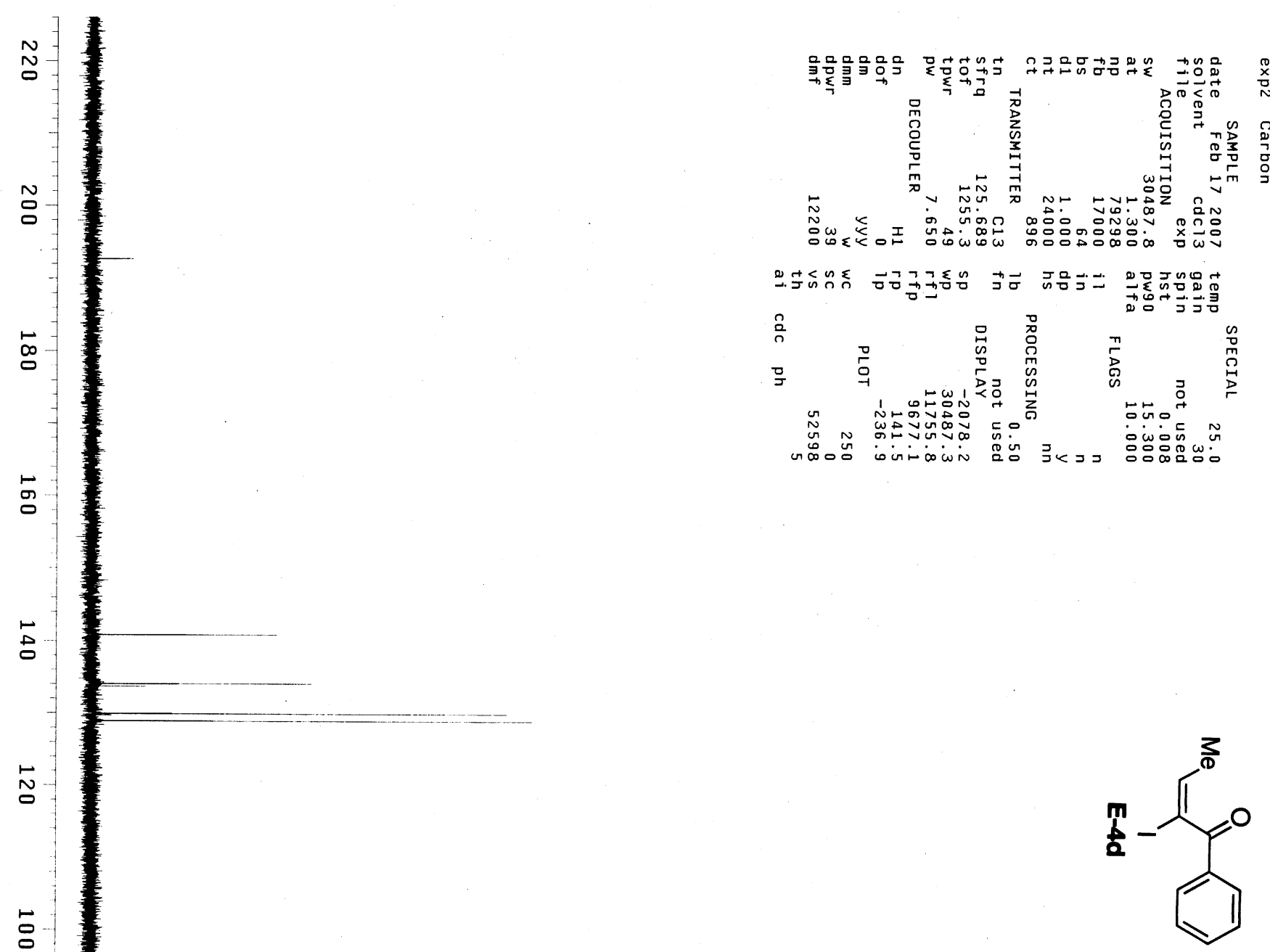

$\stackrel{\infty}{\circ}$

啨政事

啨政事

$\stackrel{b}{\circ}$

$\stackrel{n}{N}$

:

N

을 

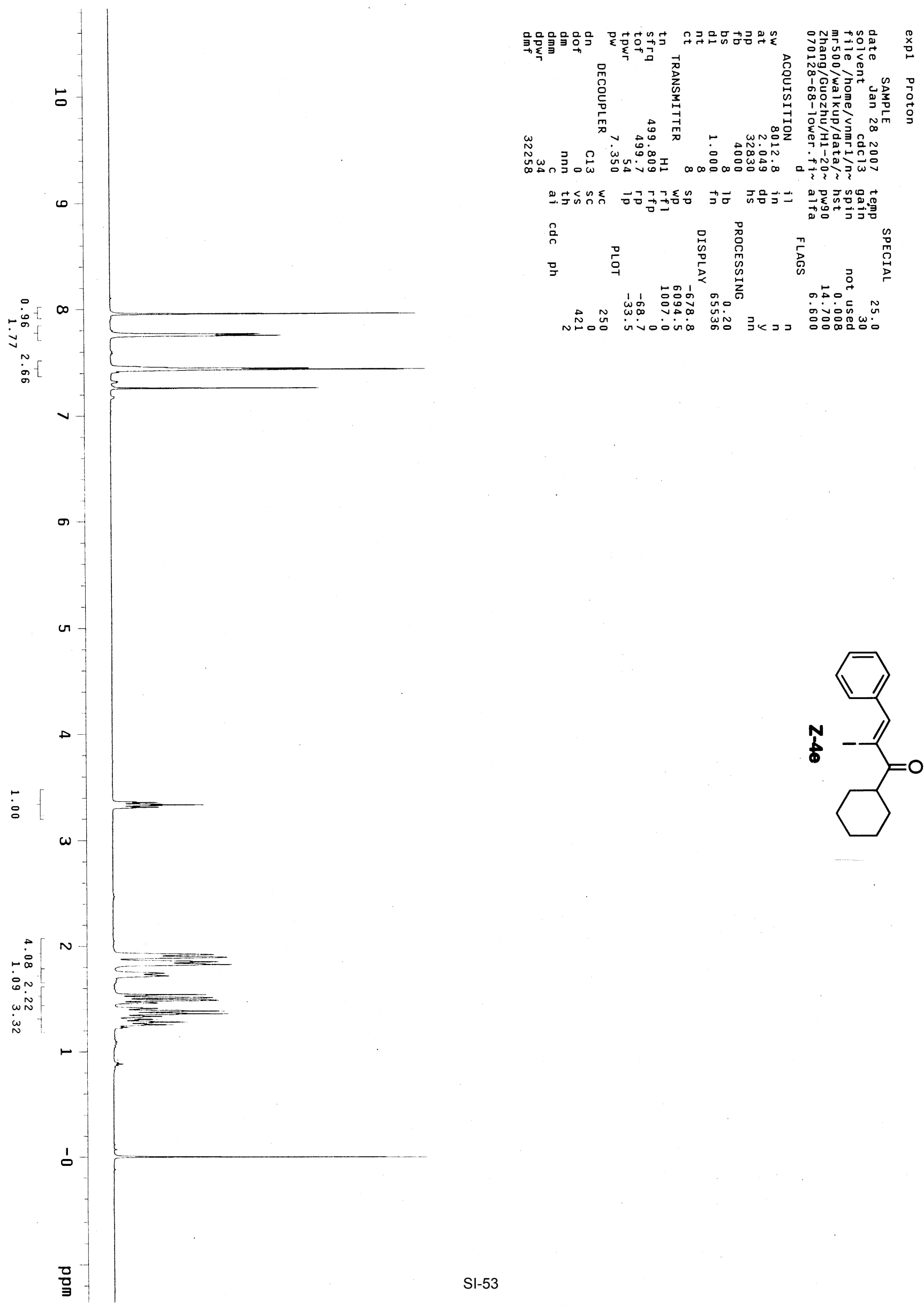


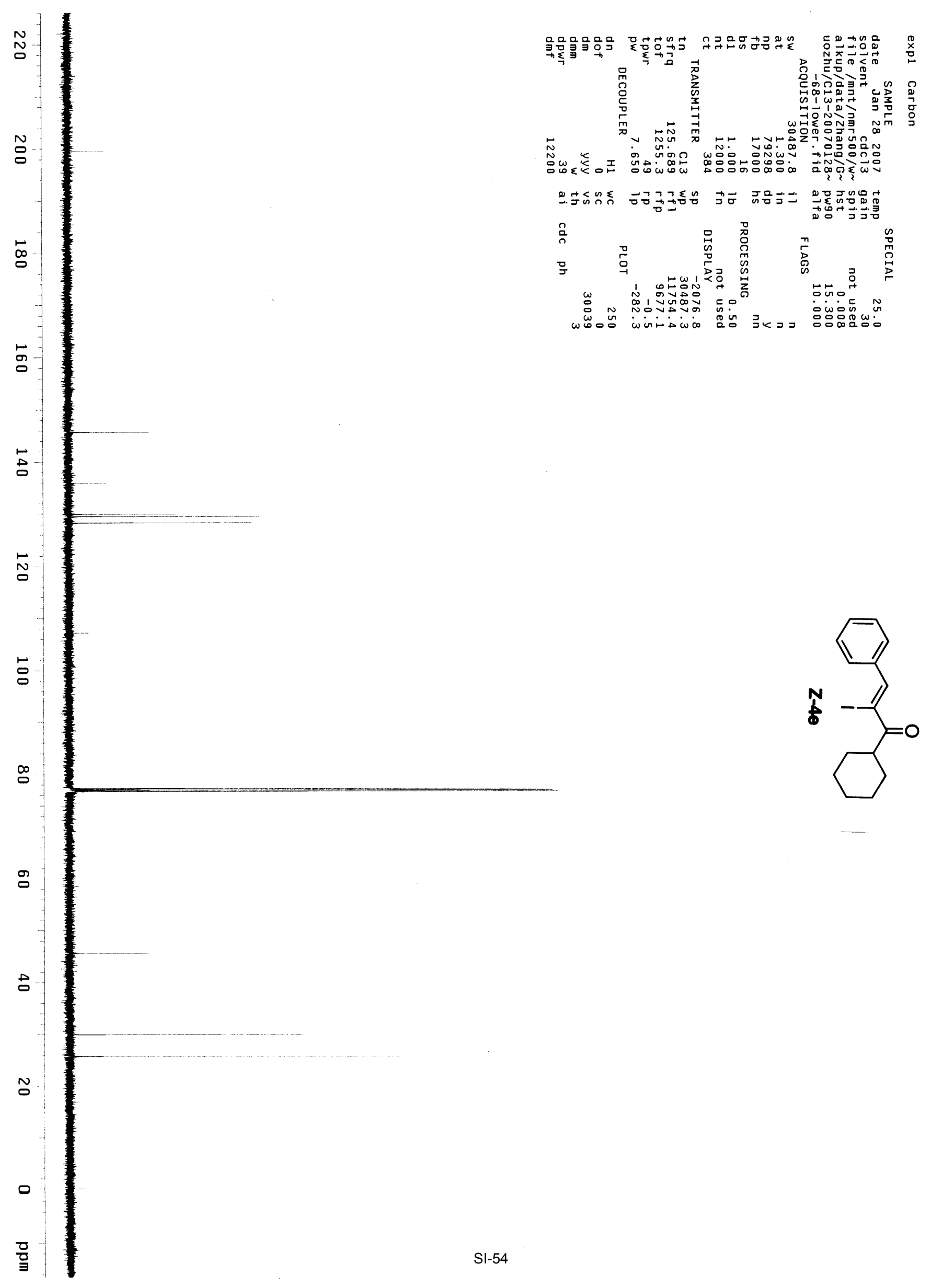




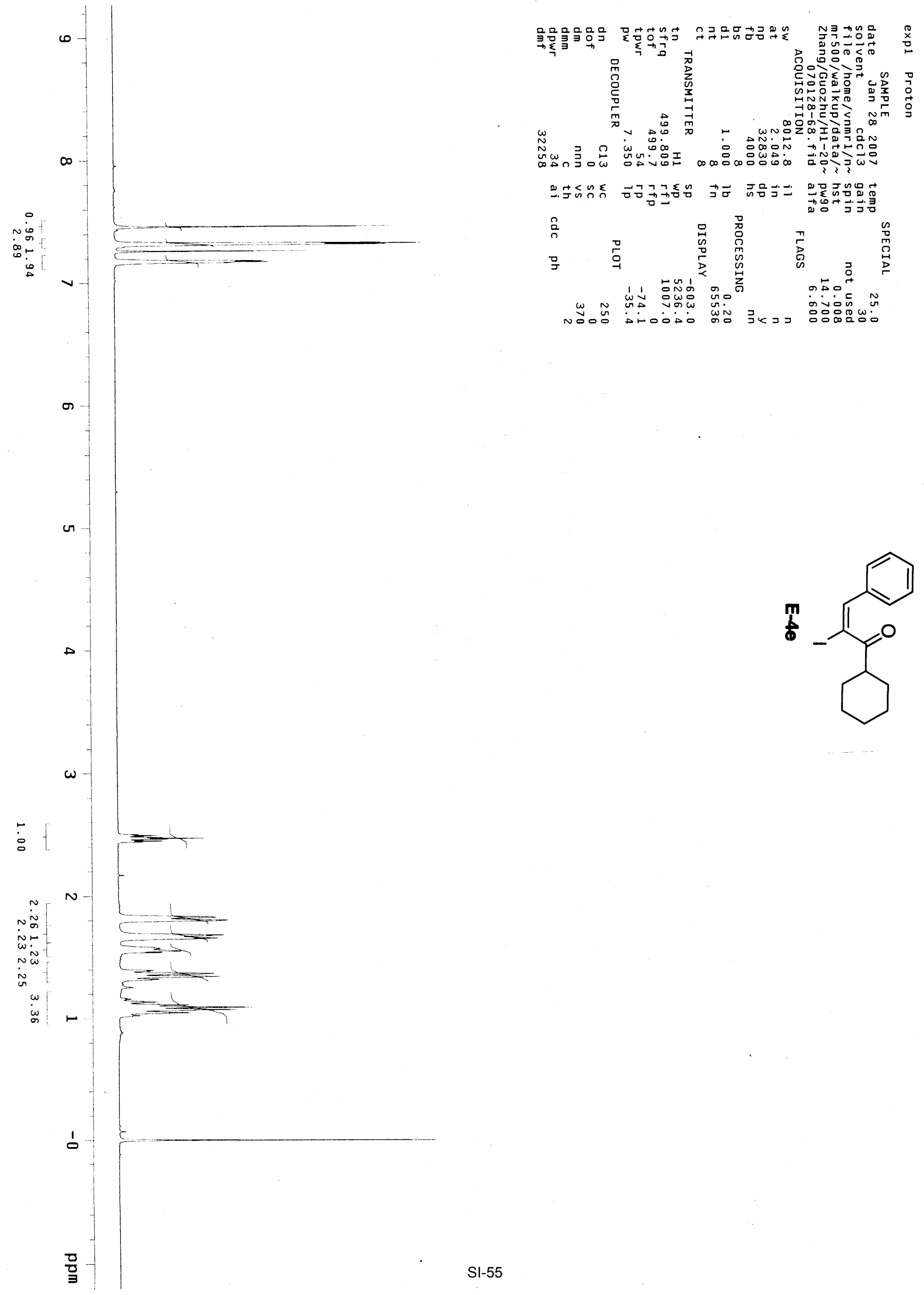




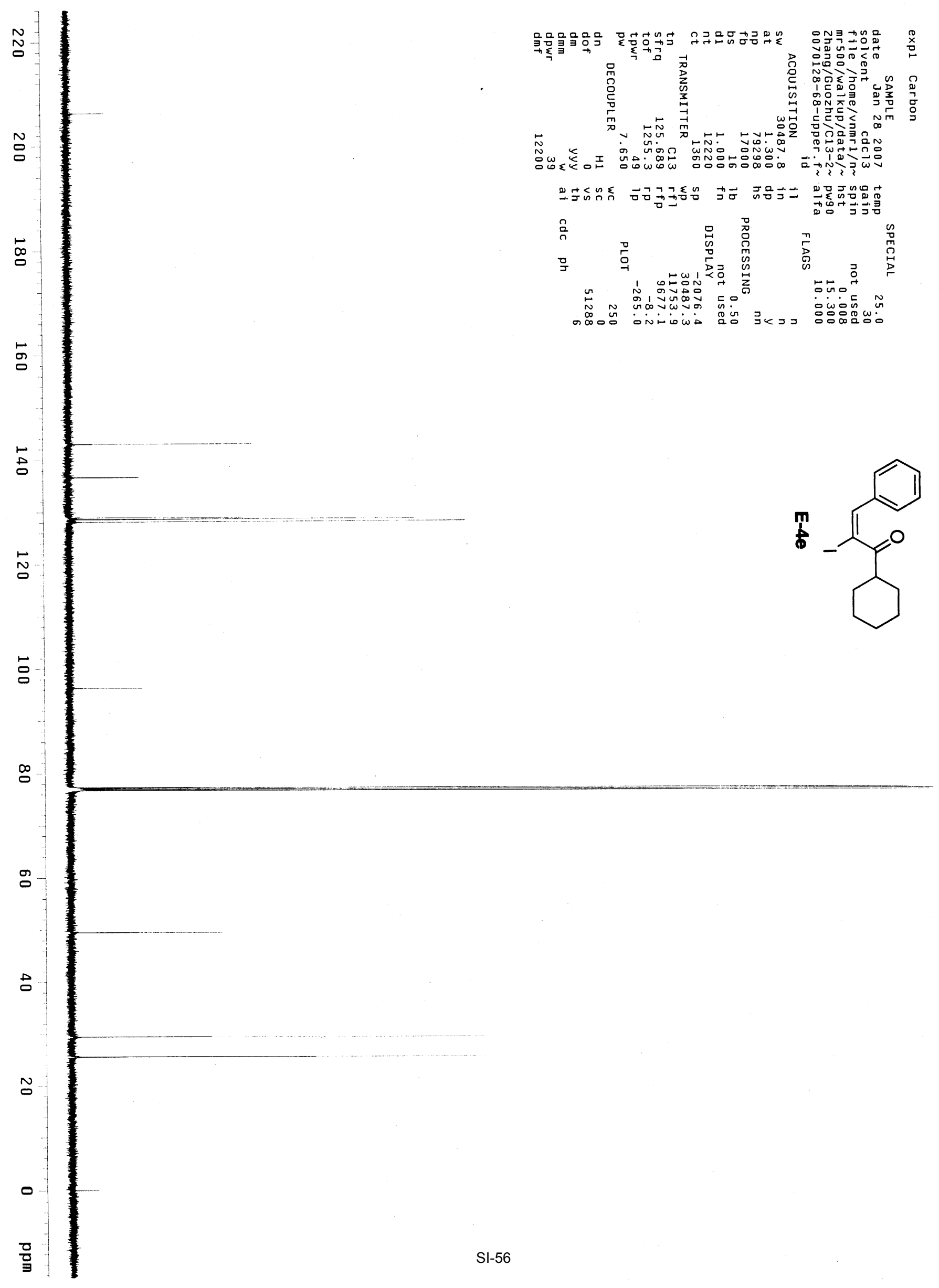




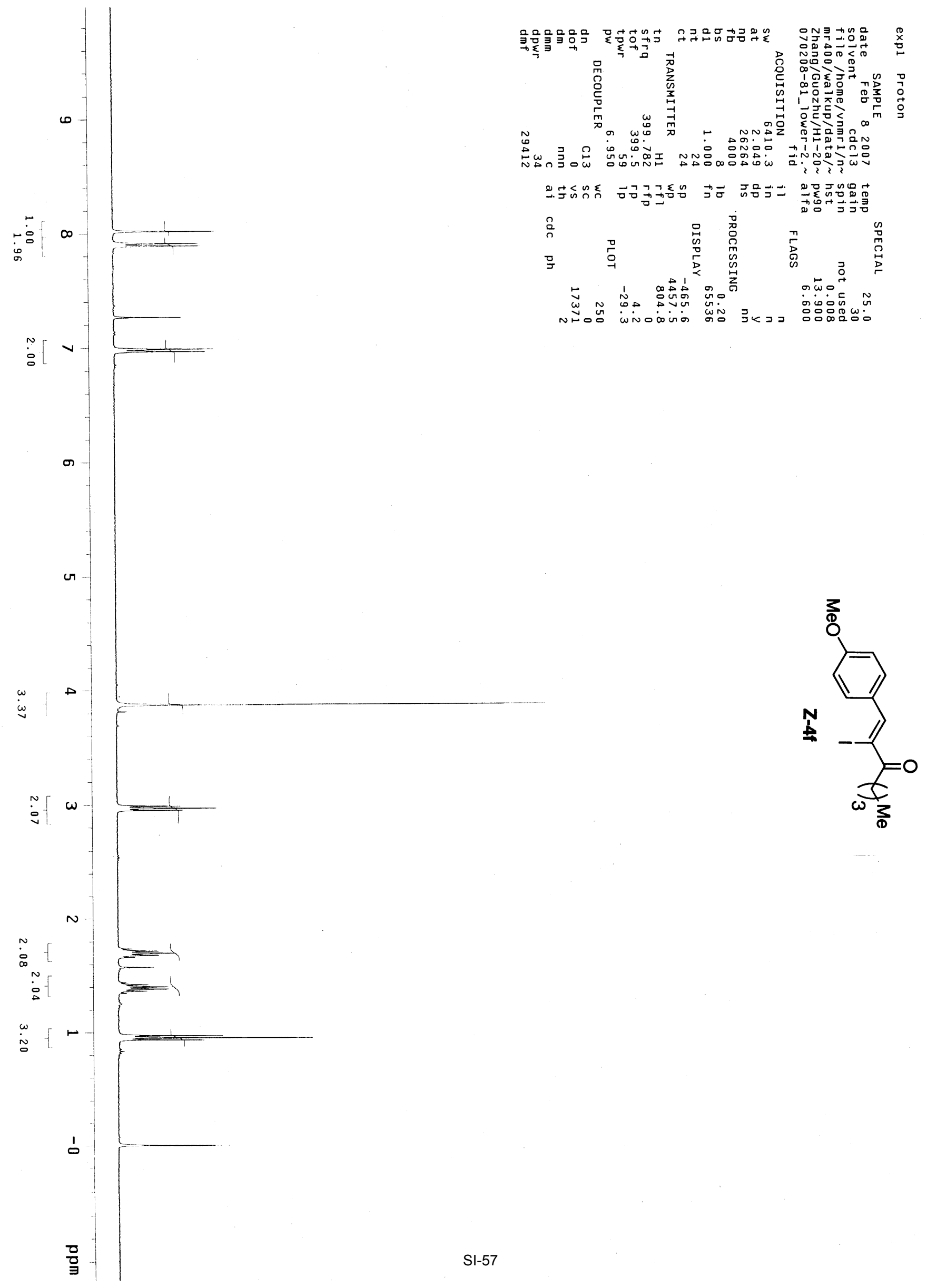




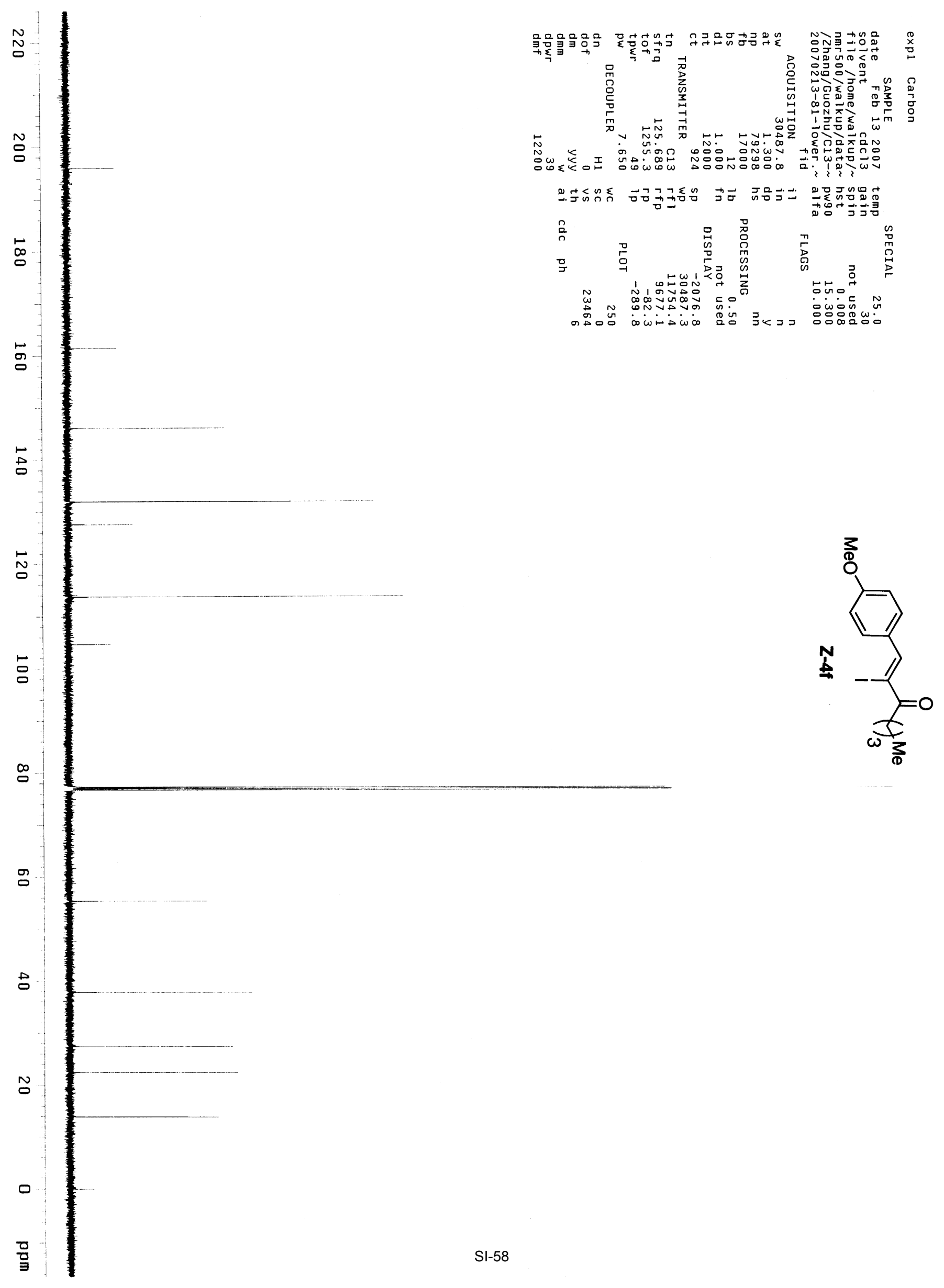




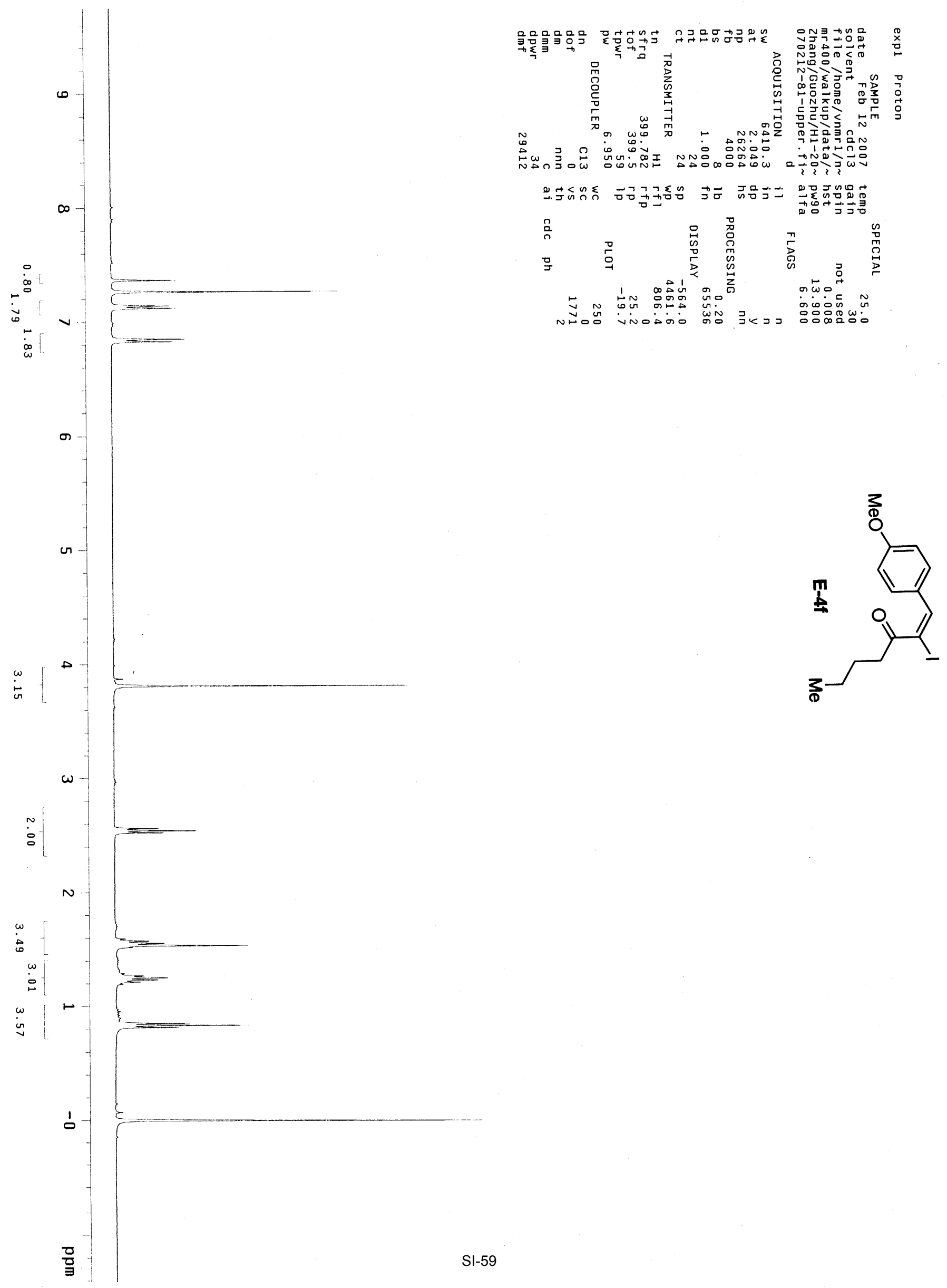




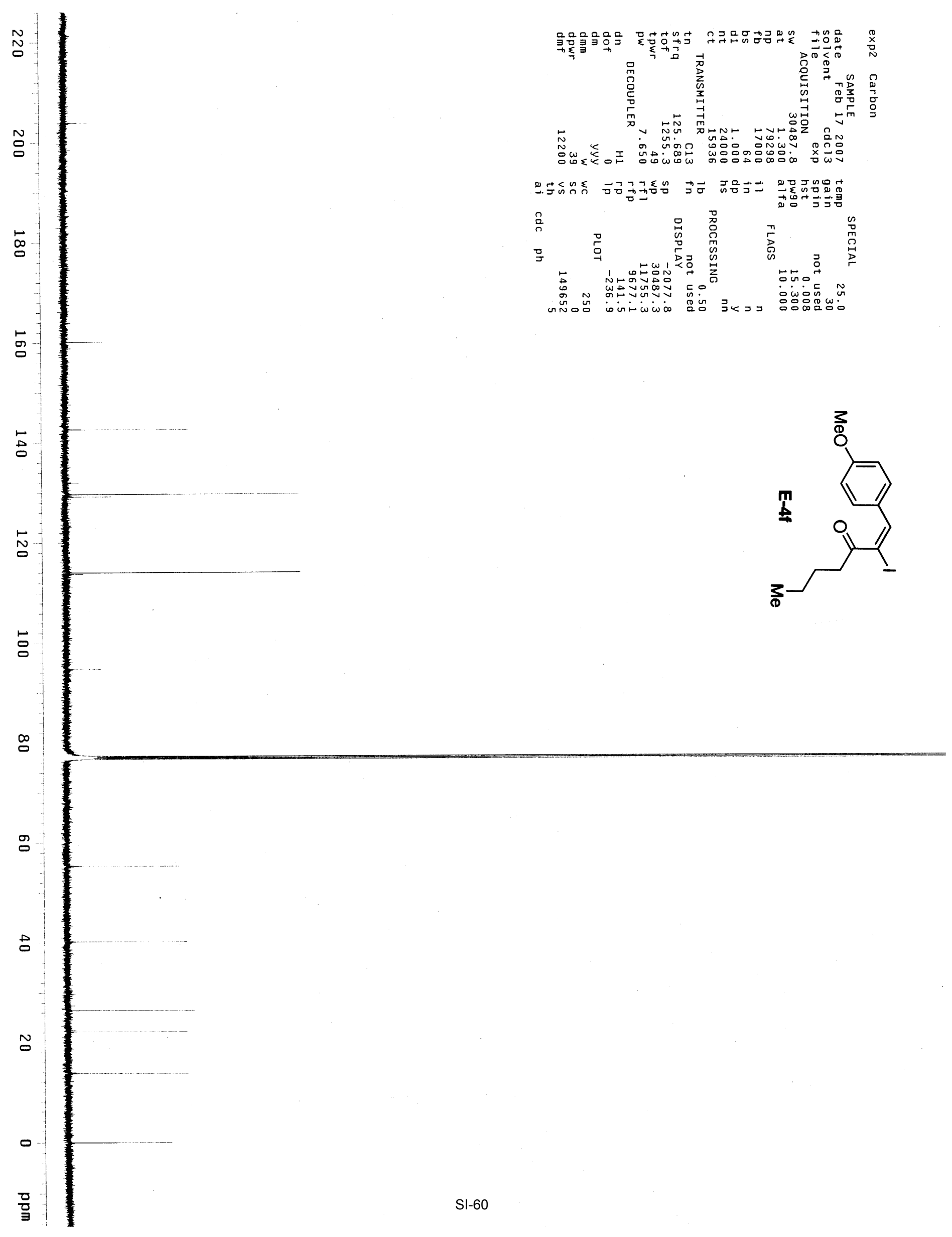



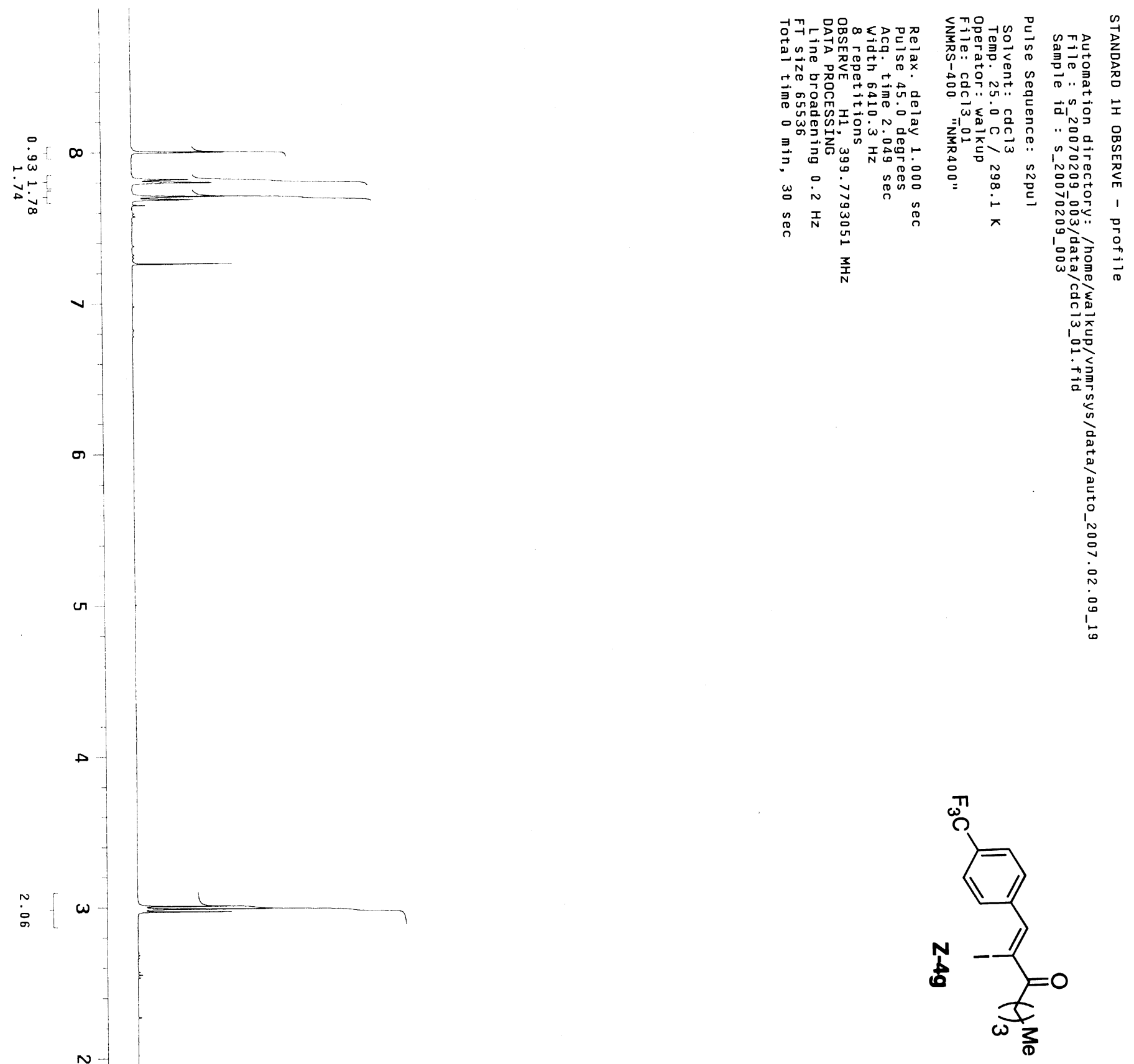


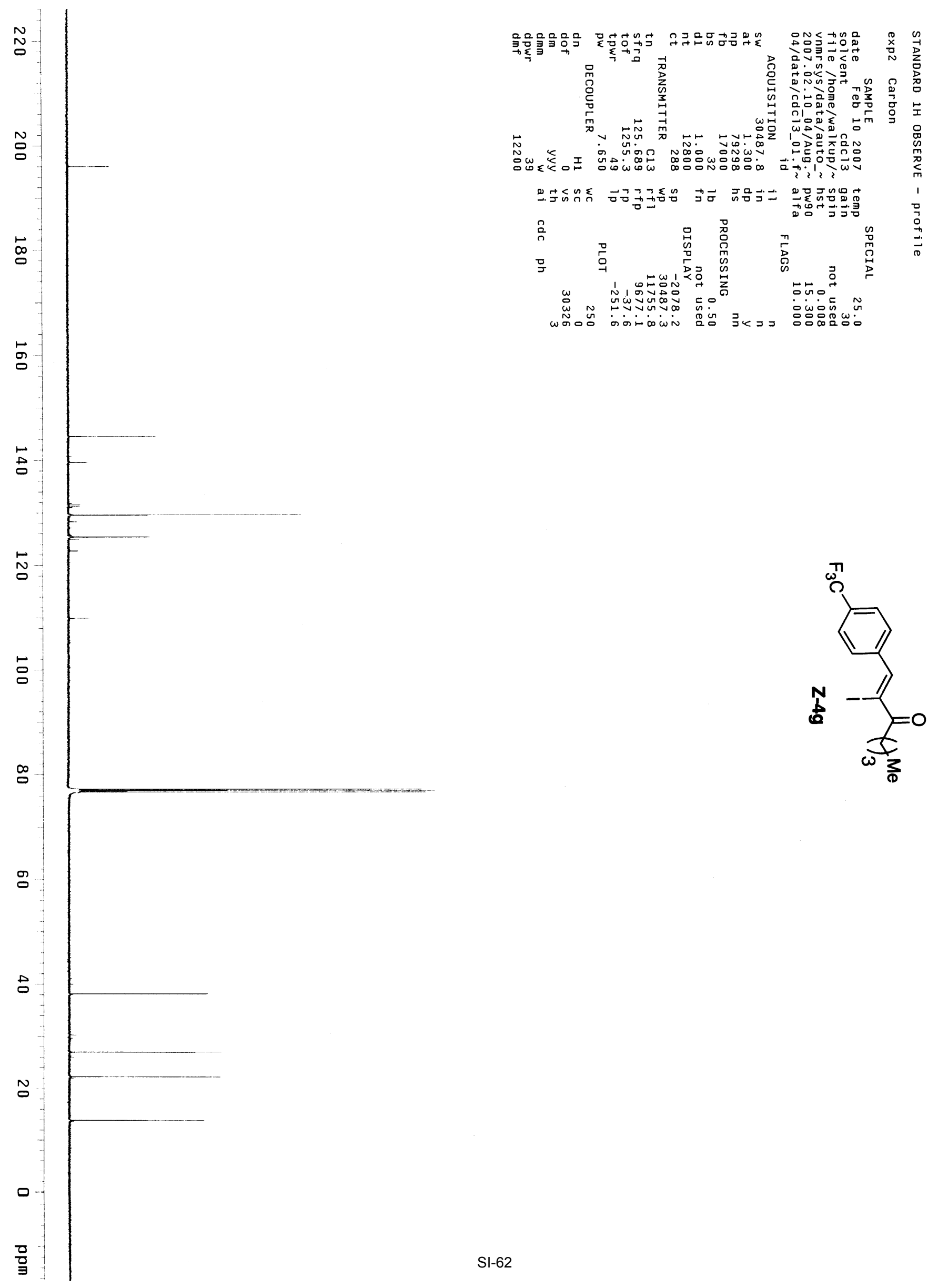




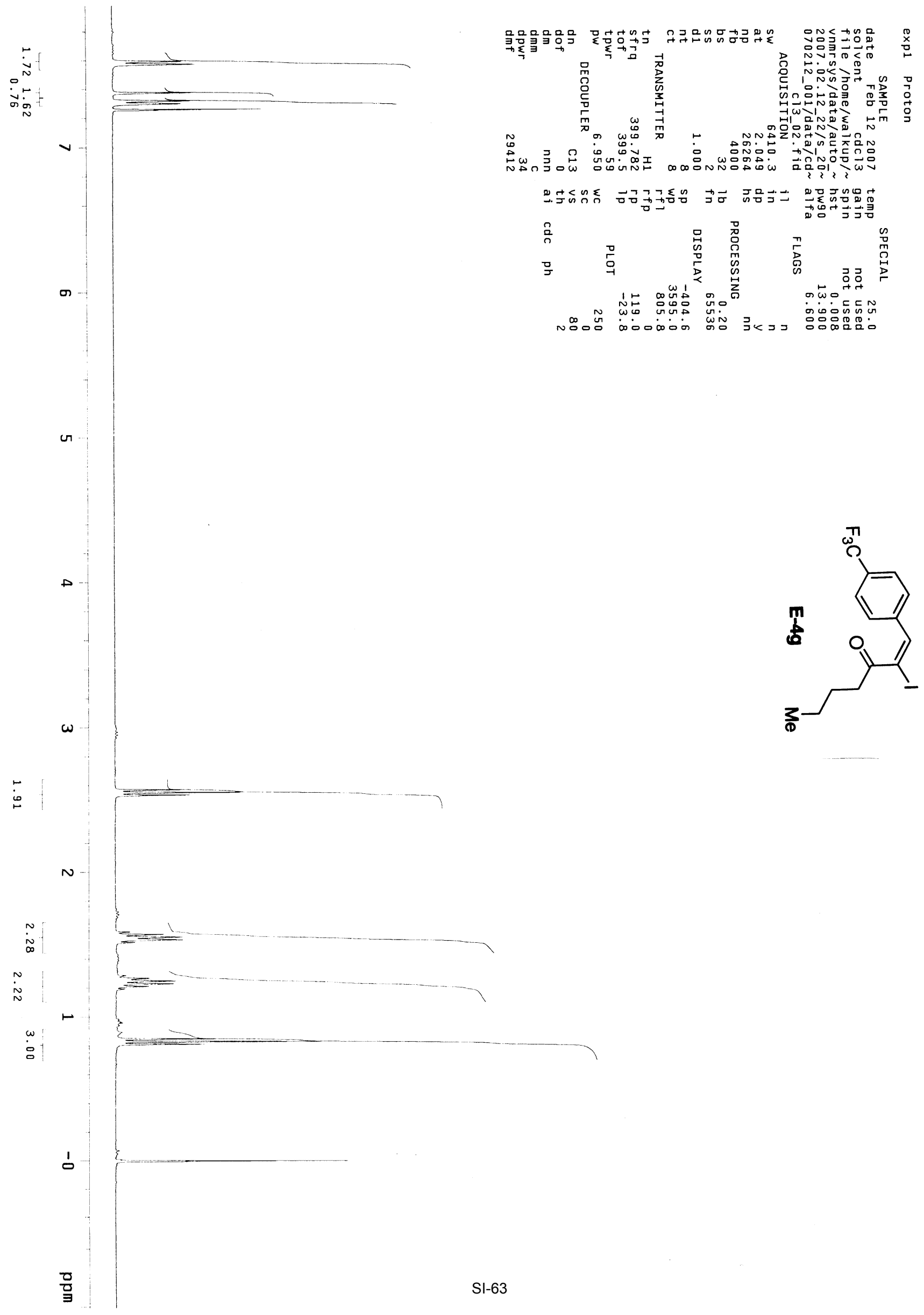




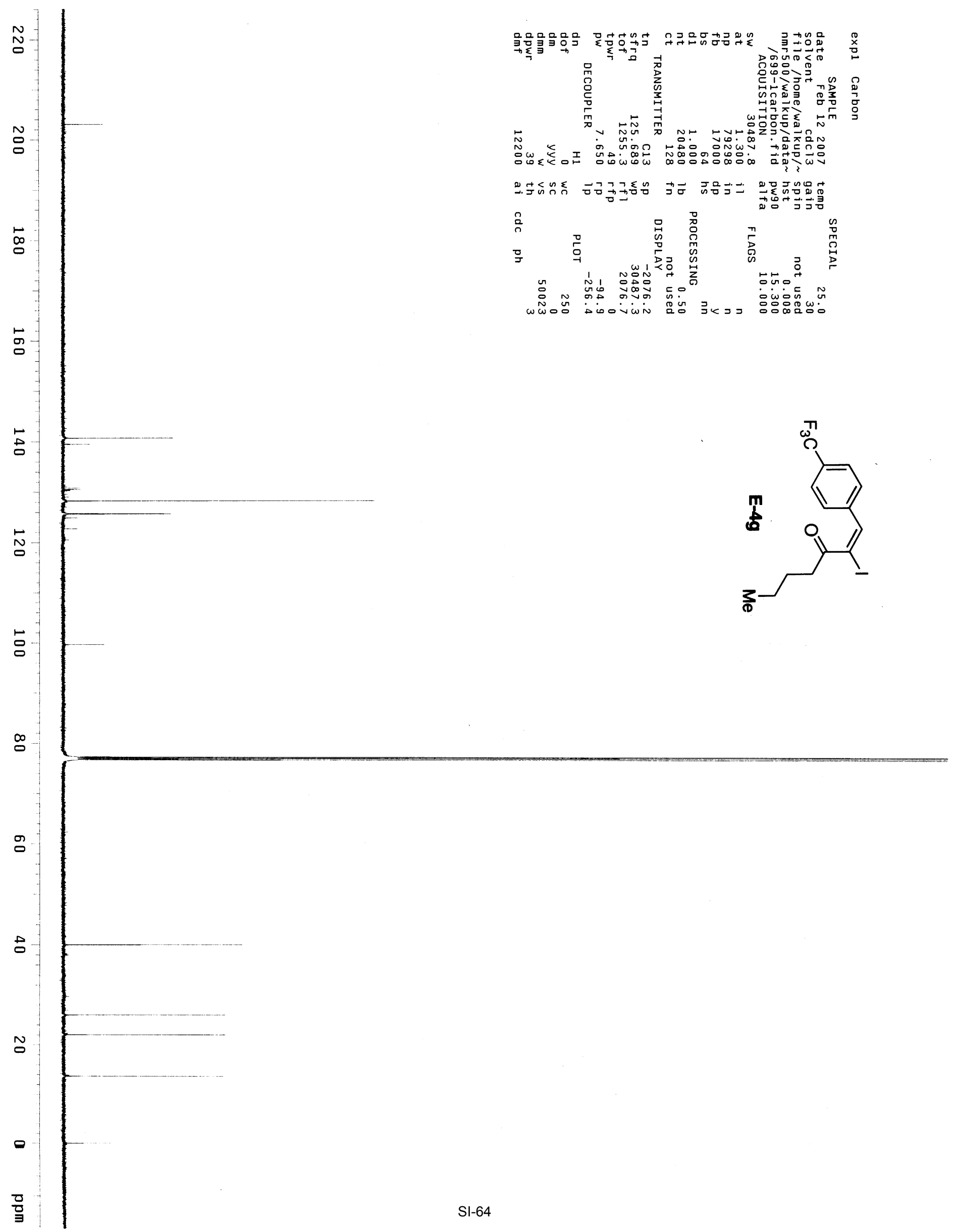




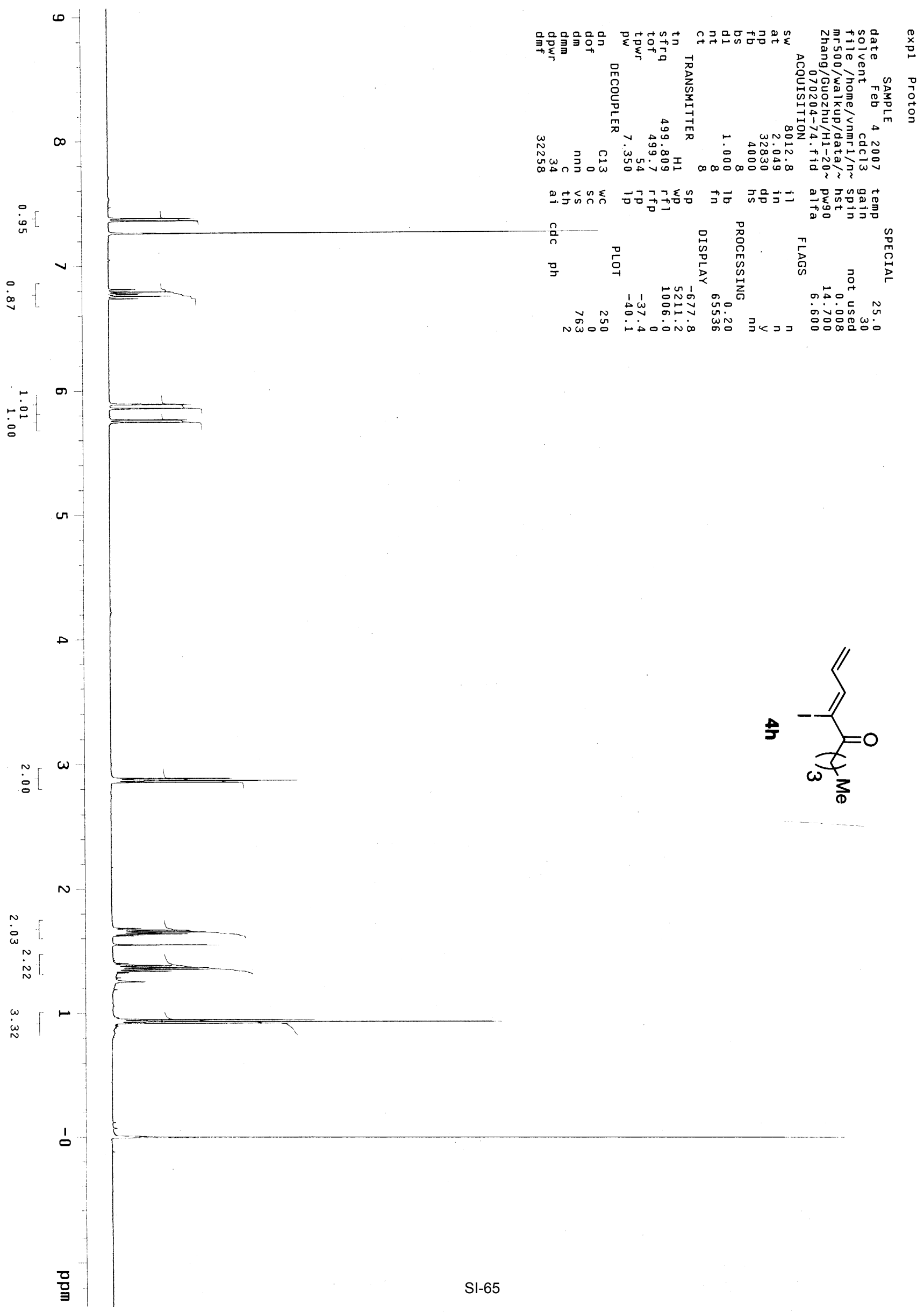




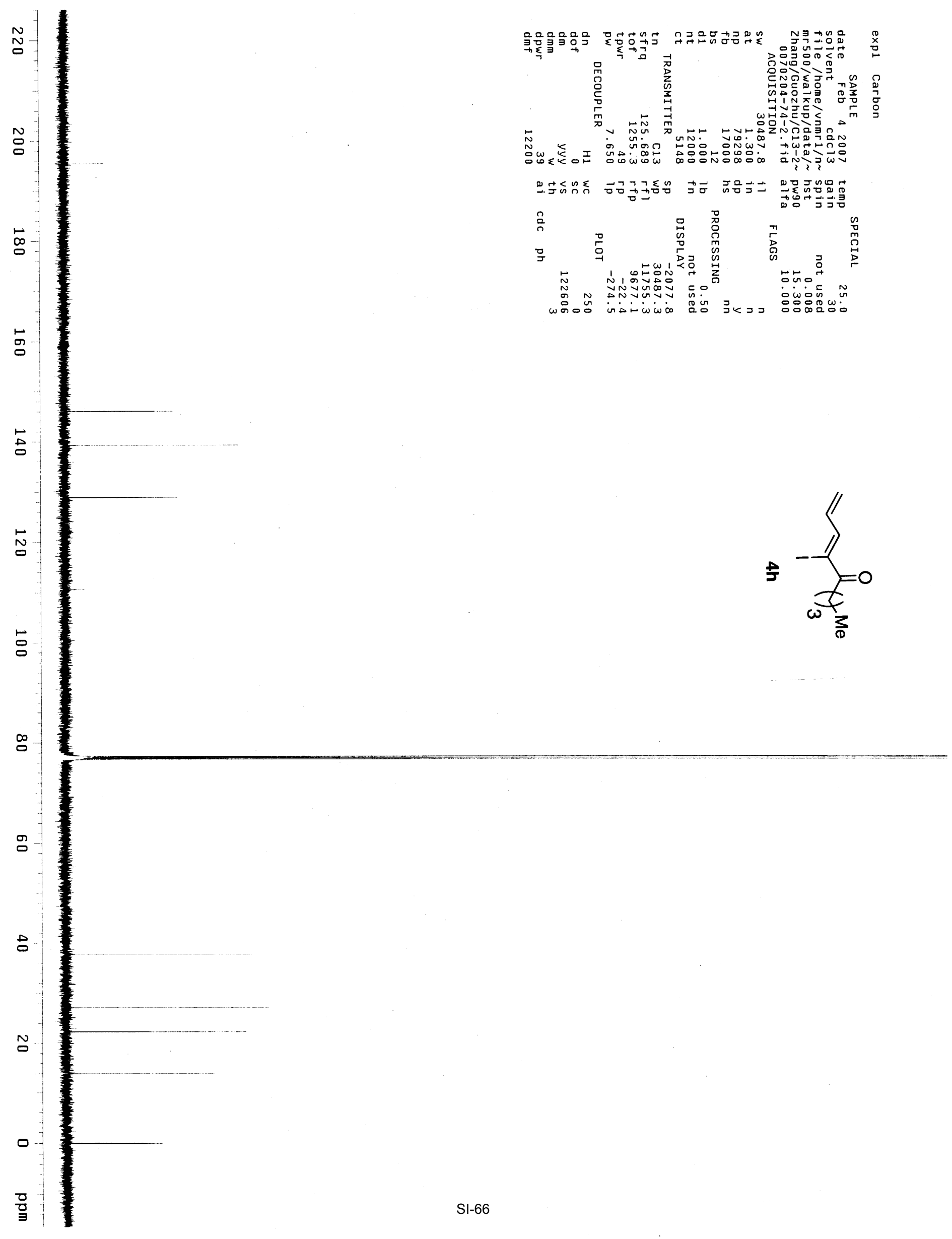



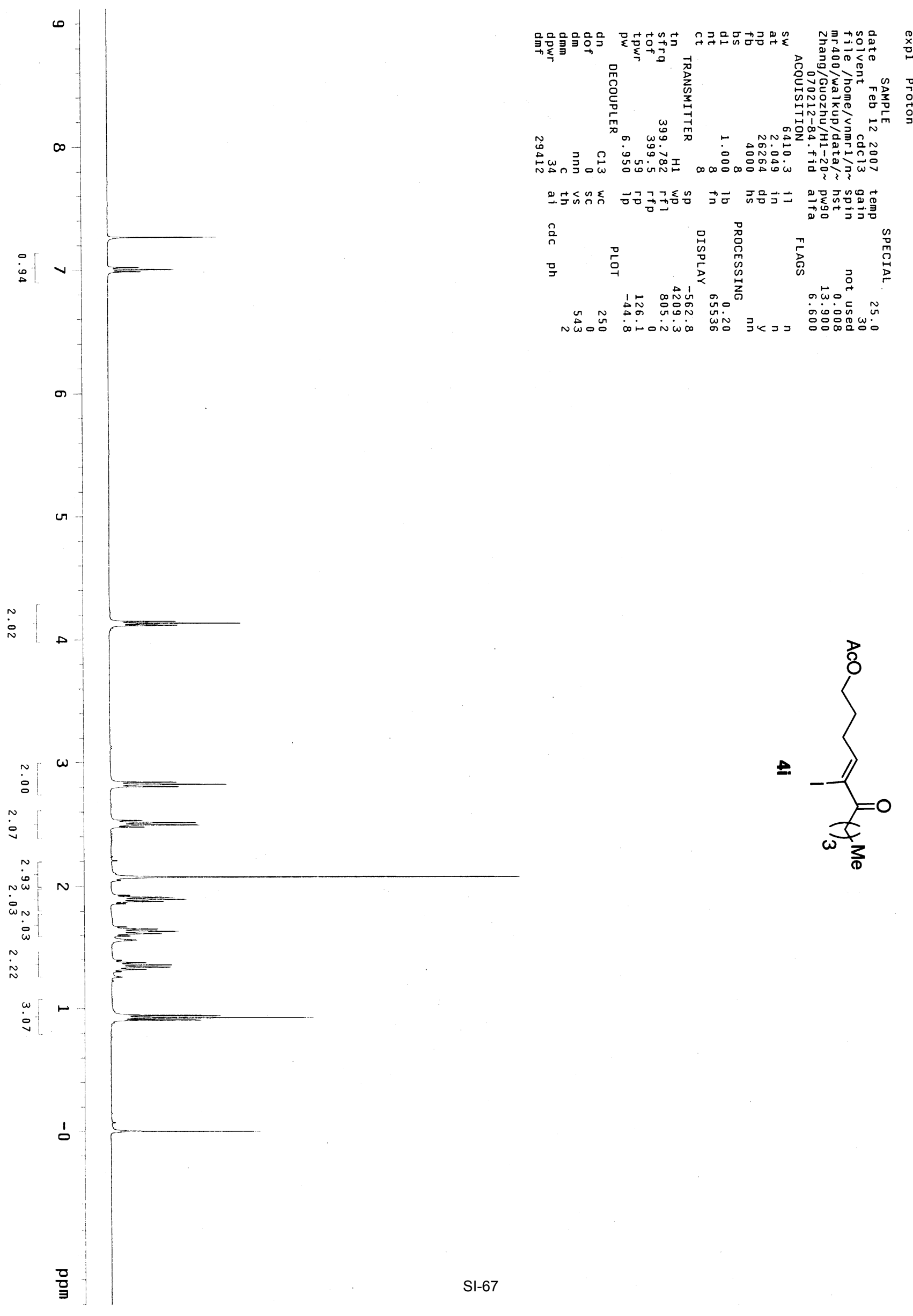

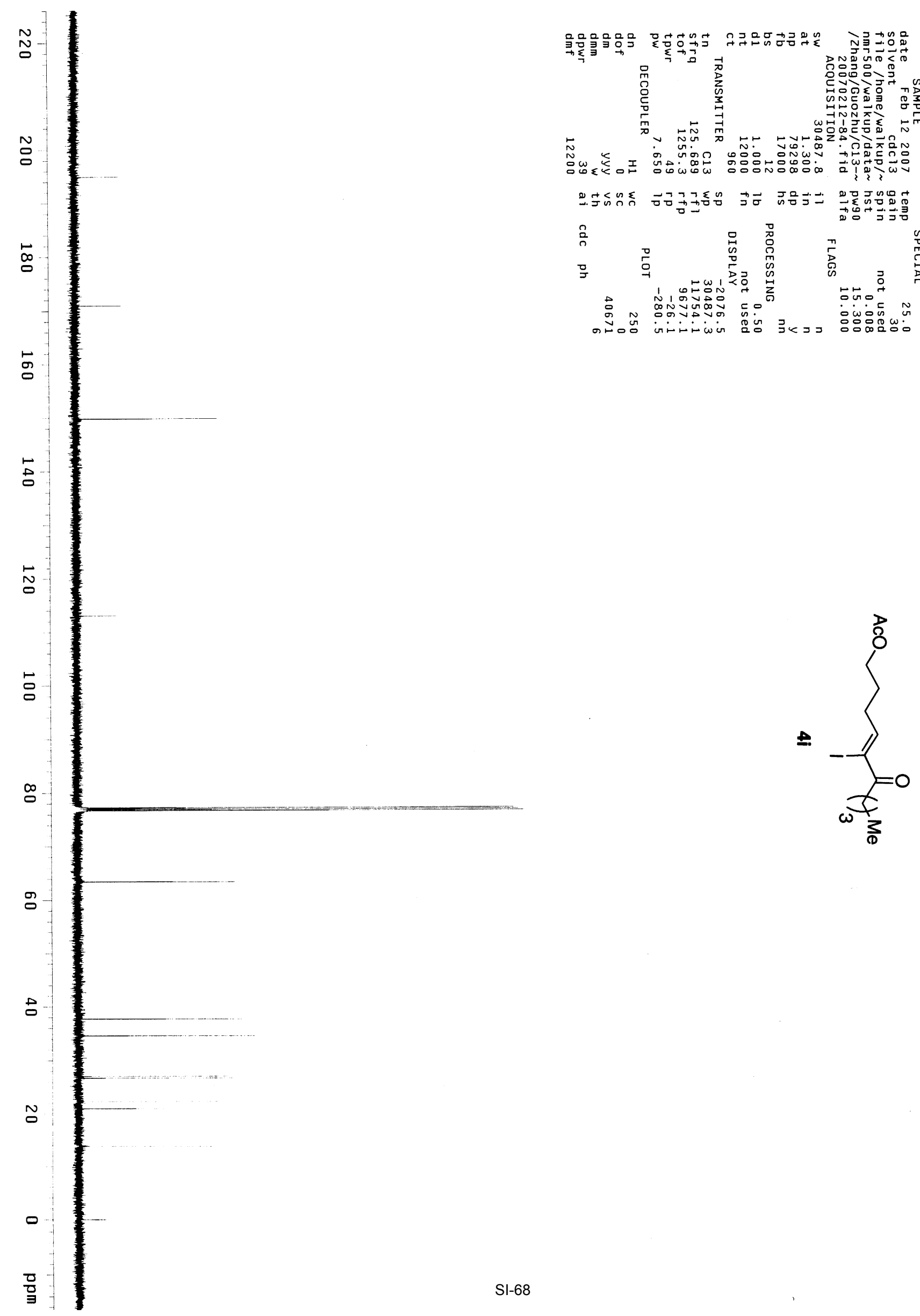

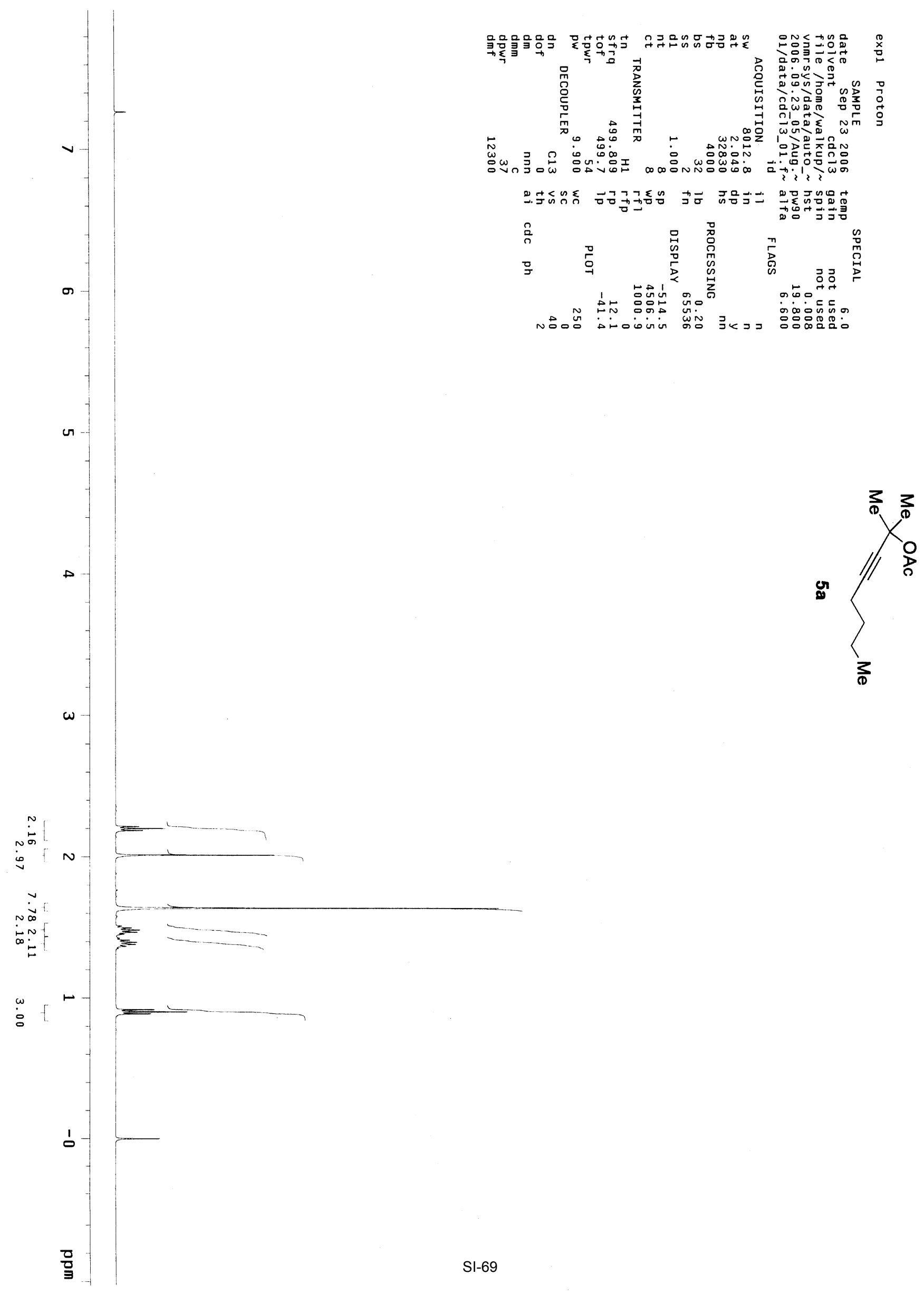

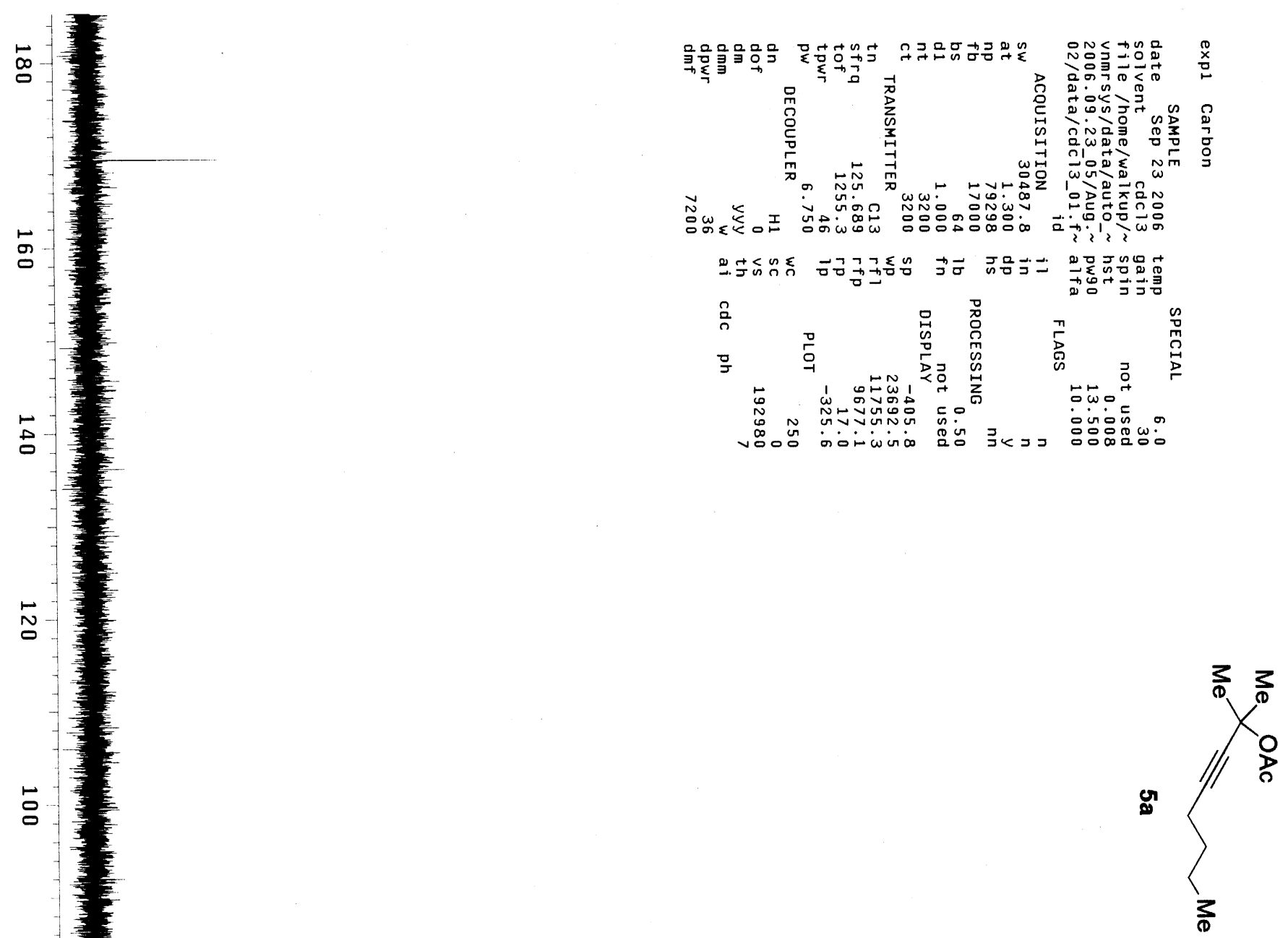

$\stackrel{\infty}{\circ}$ 


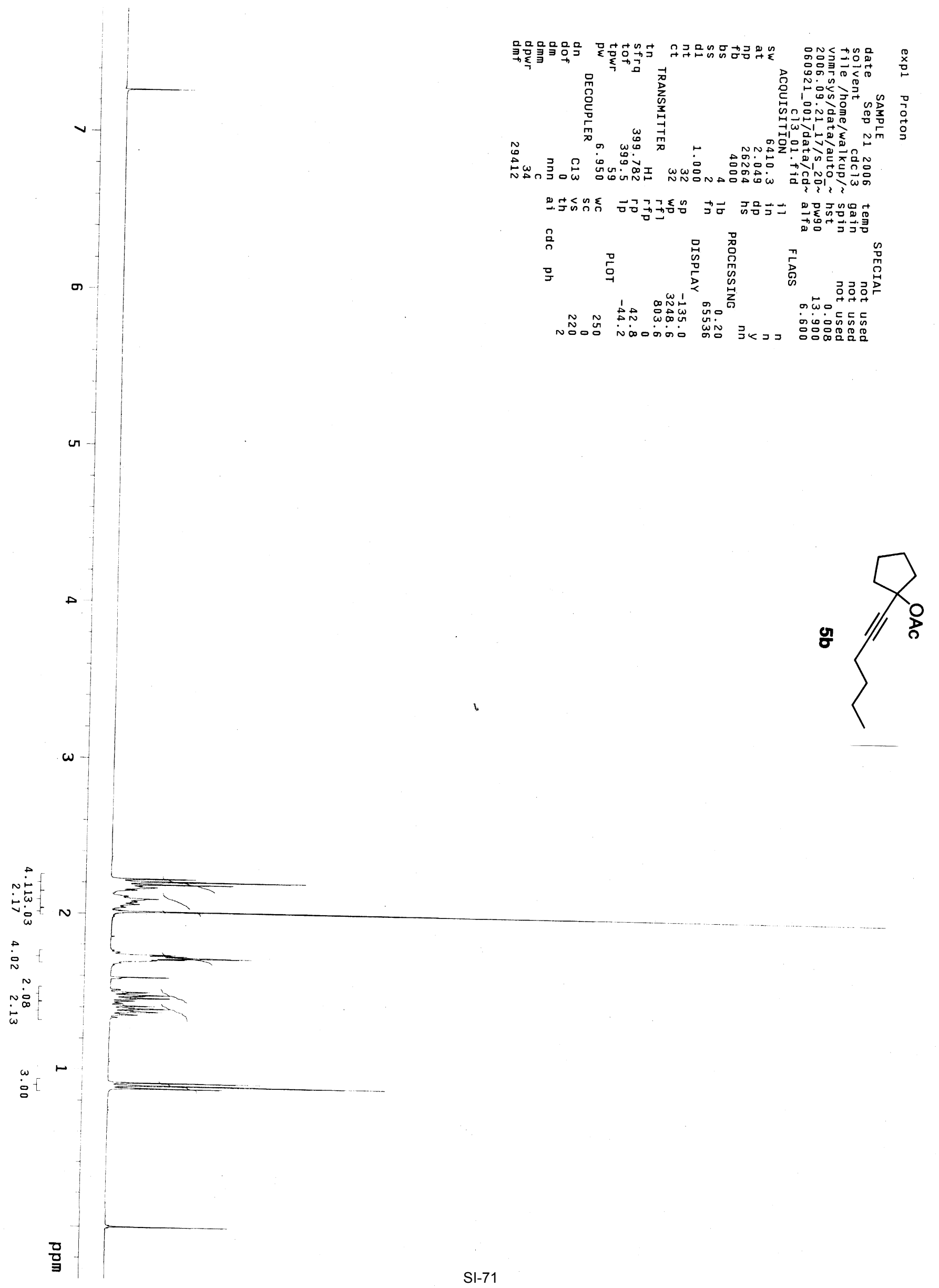




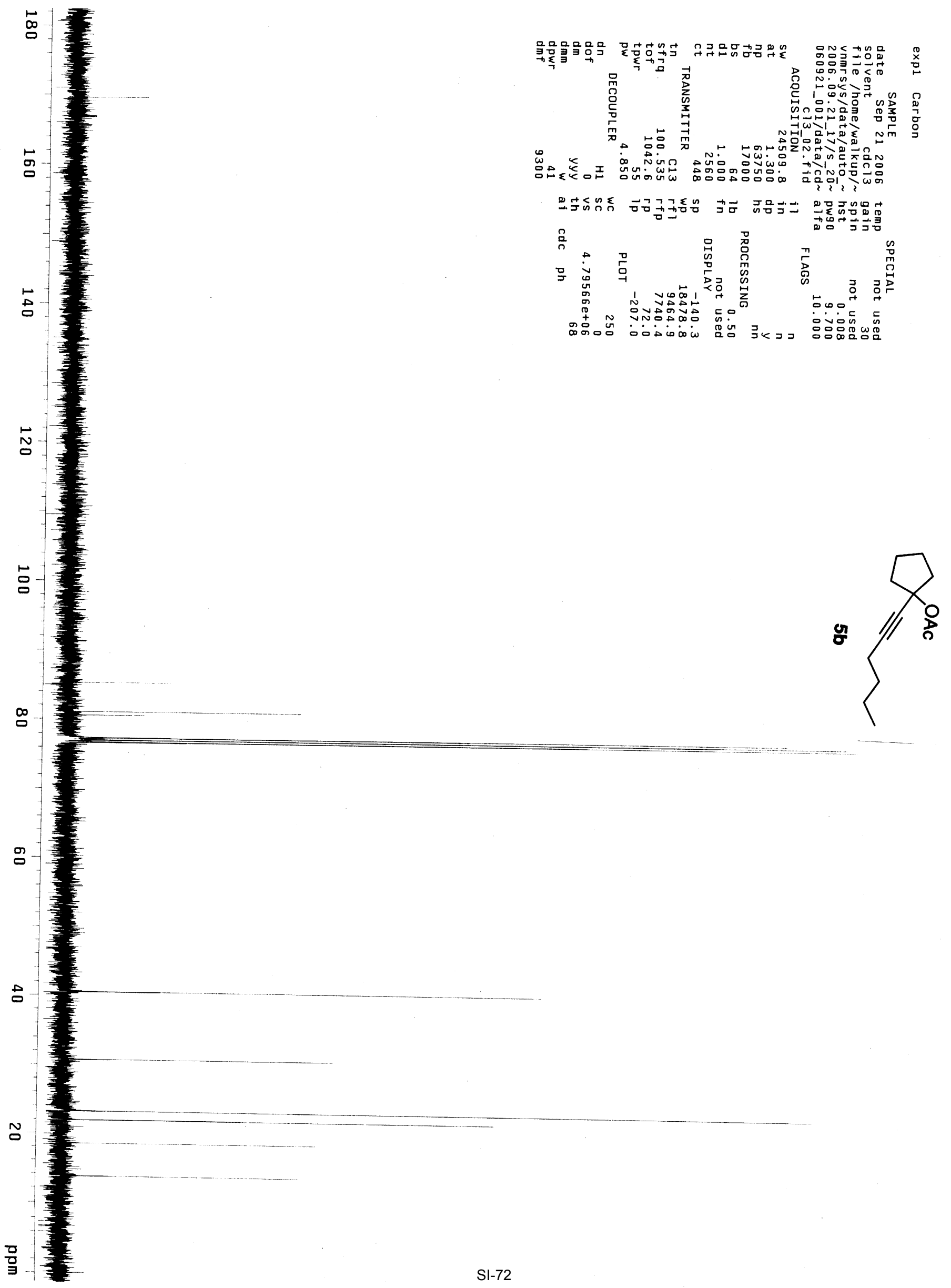




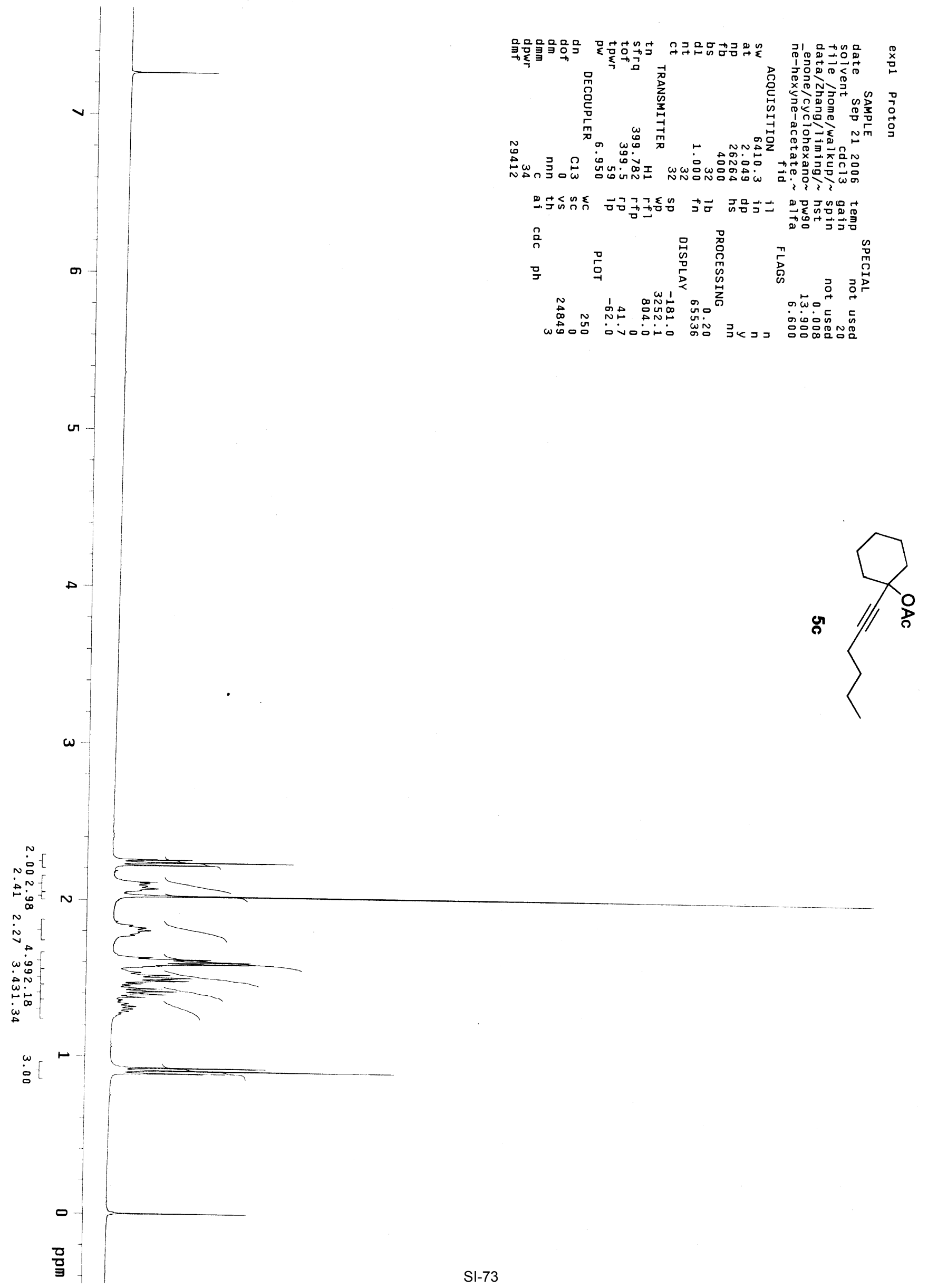




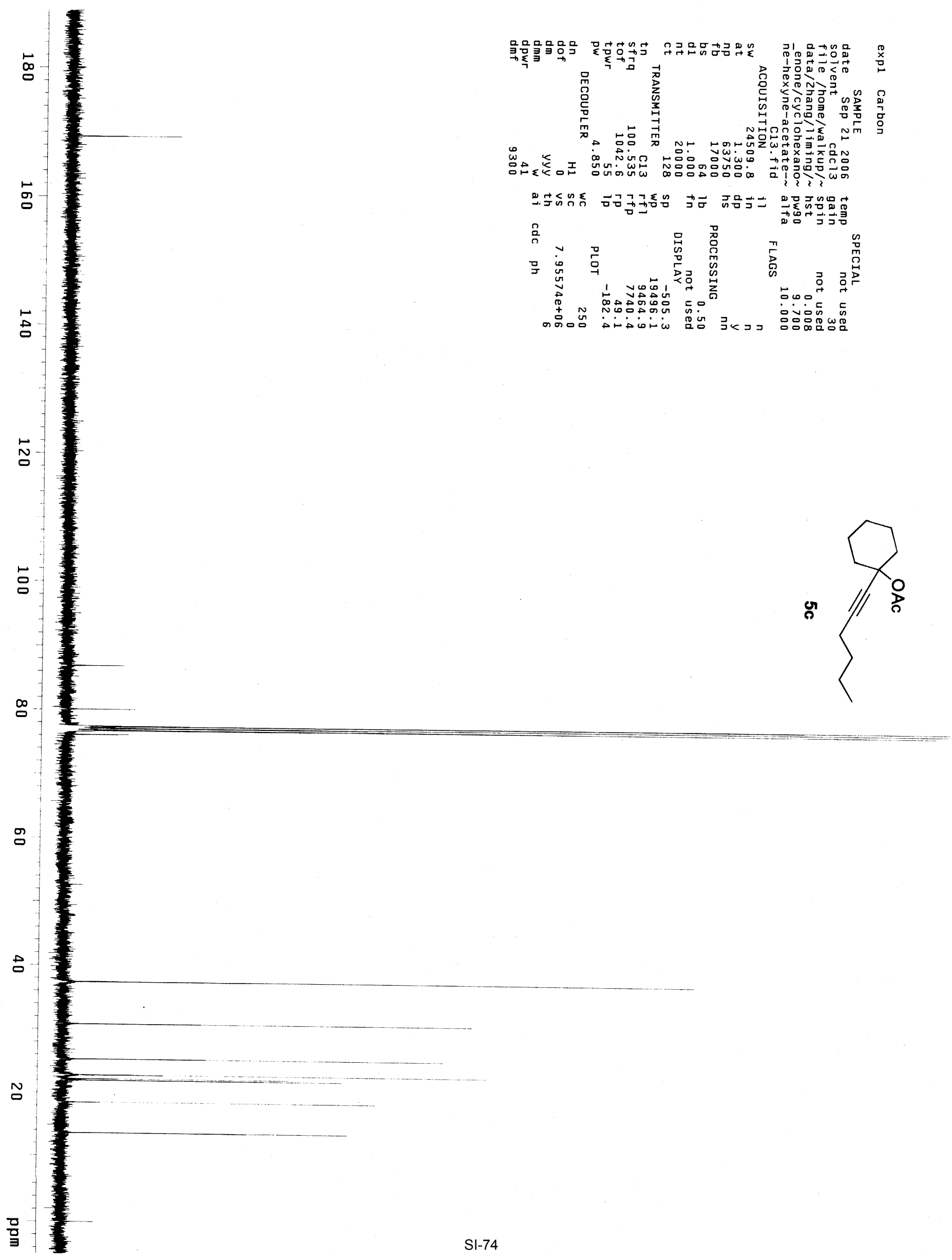




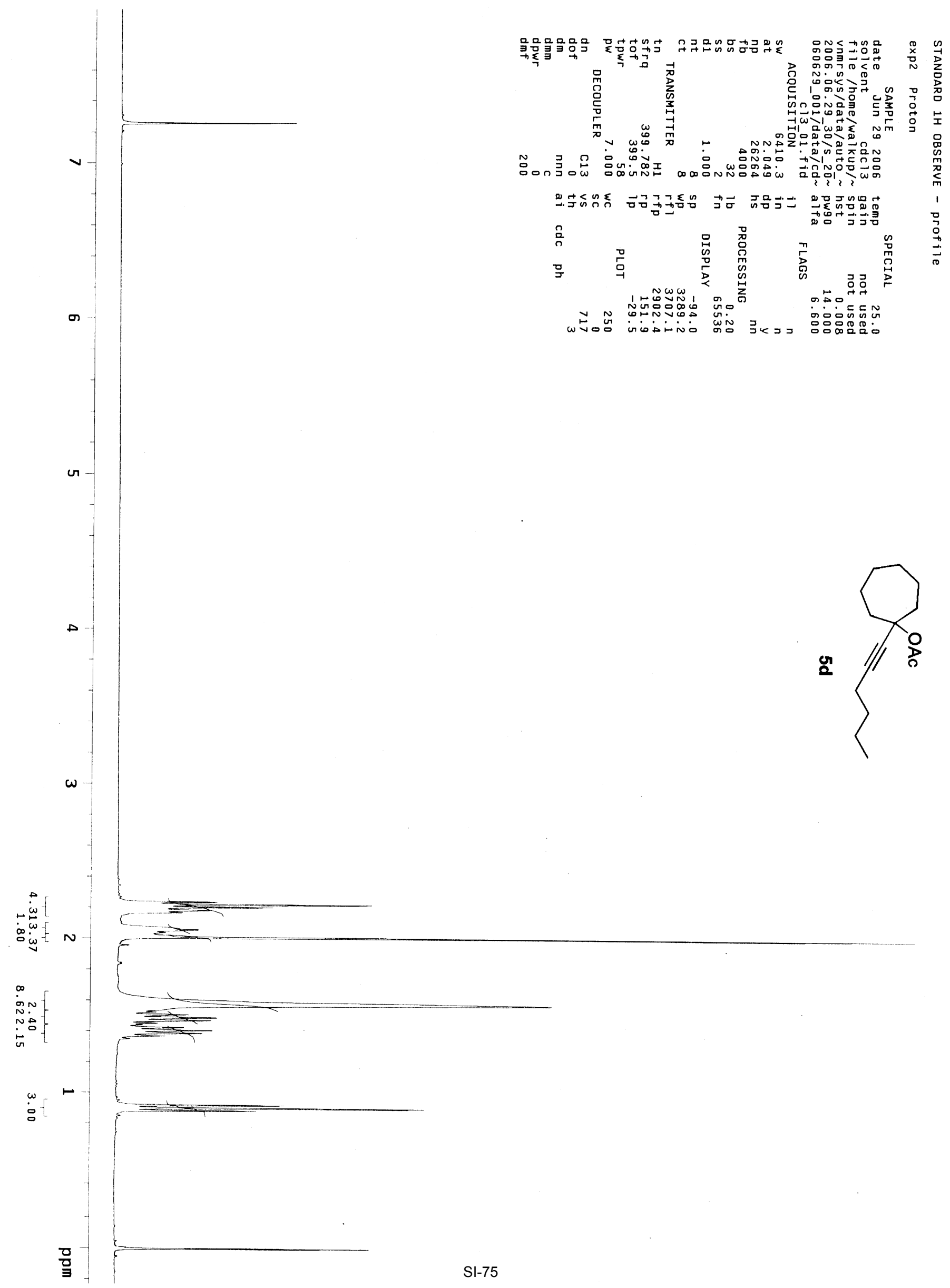




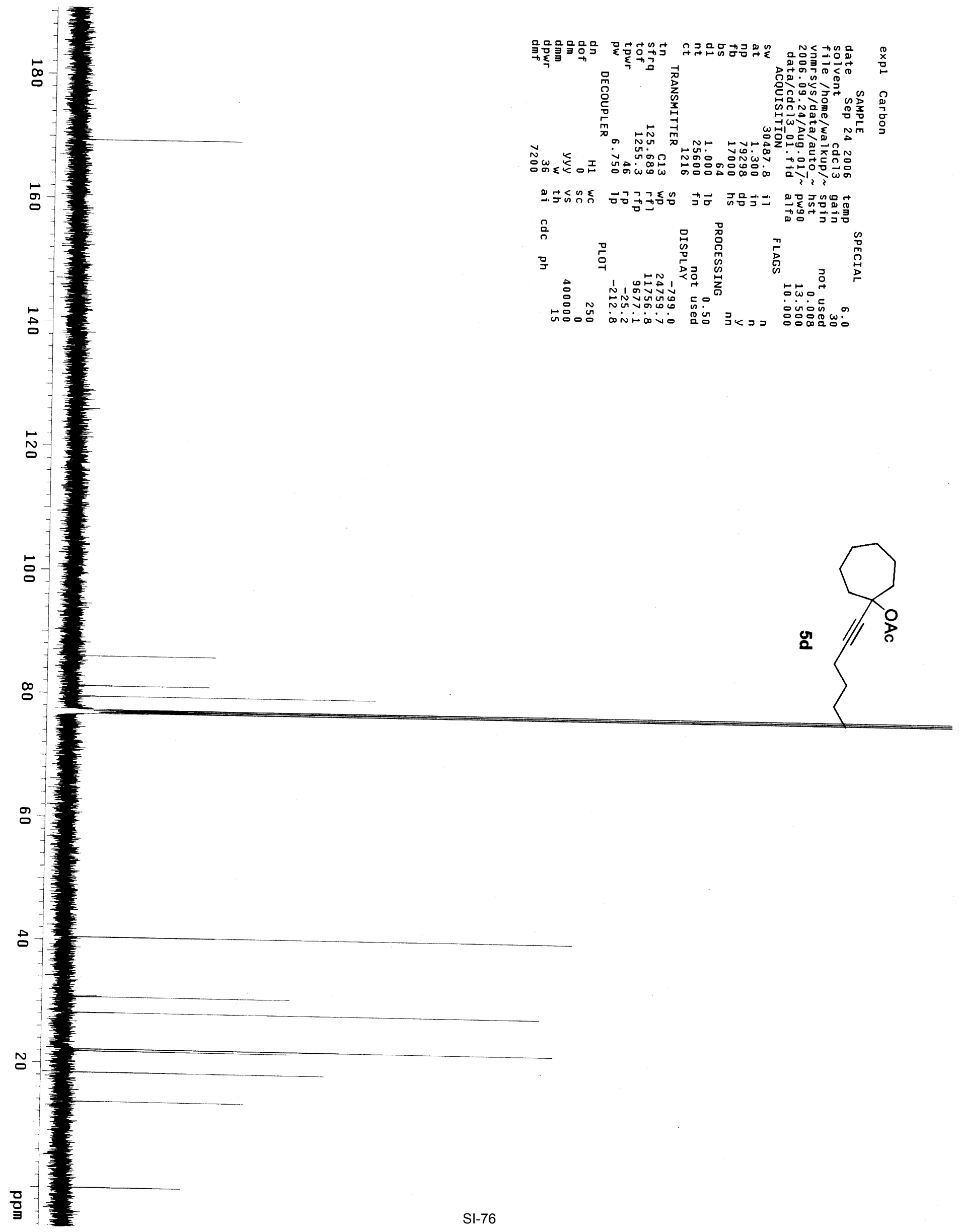




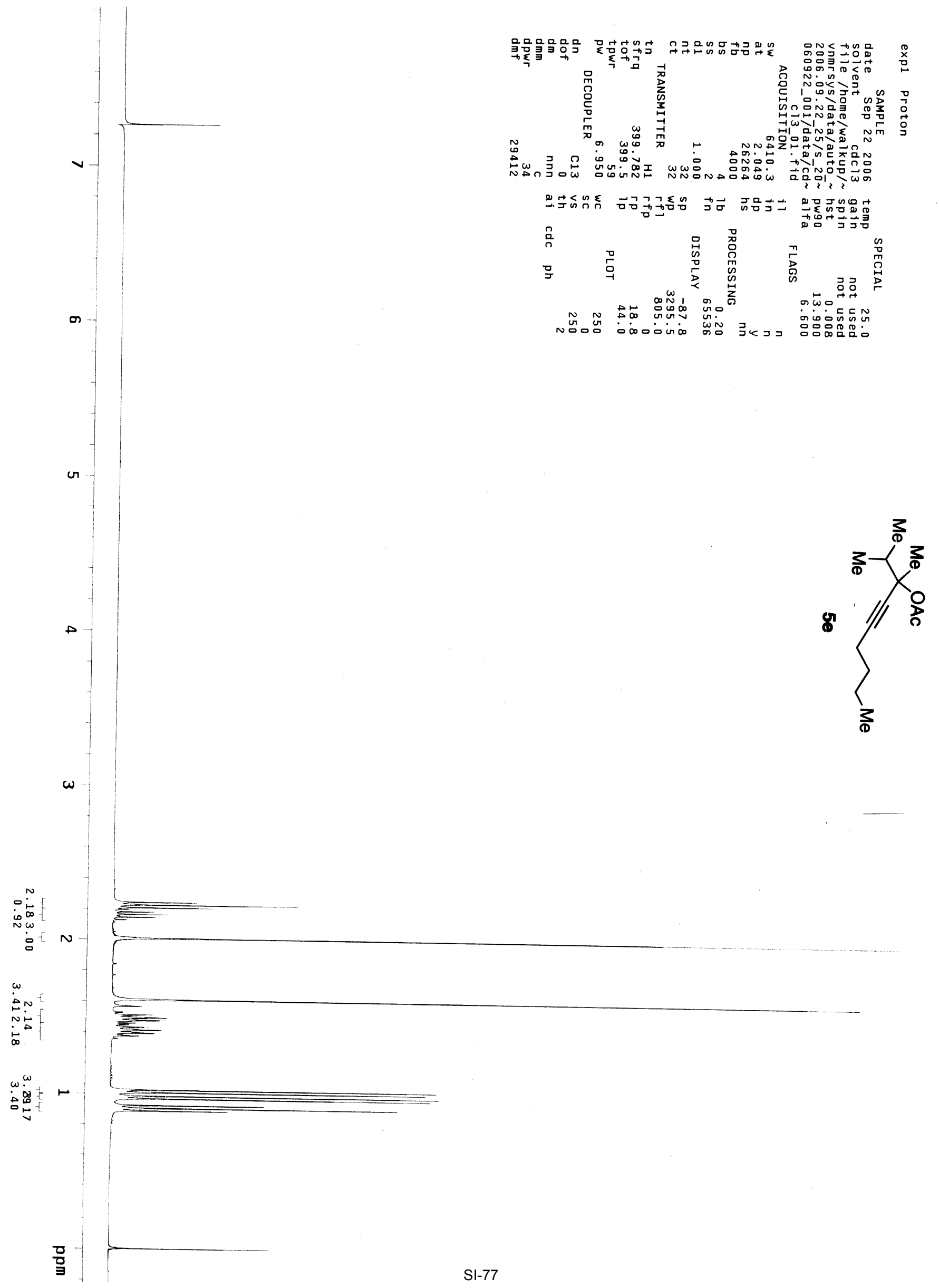




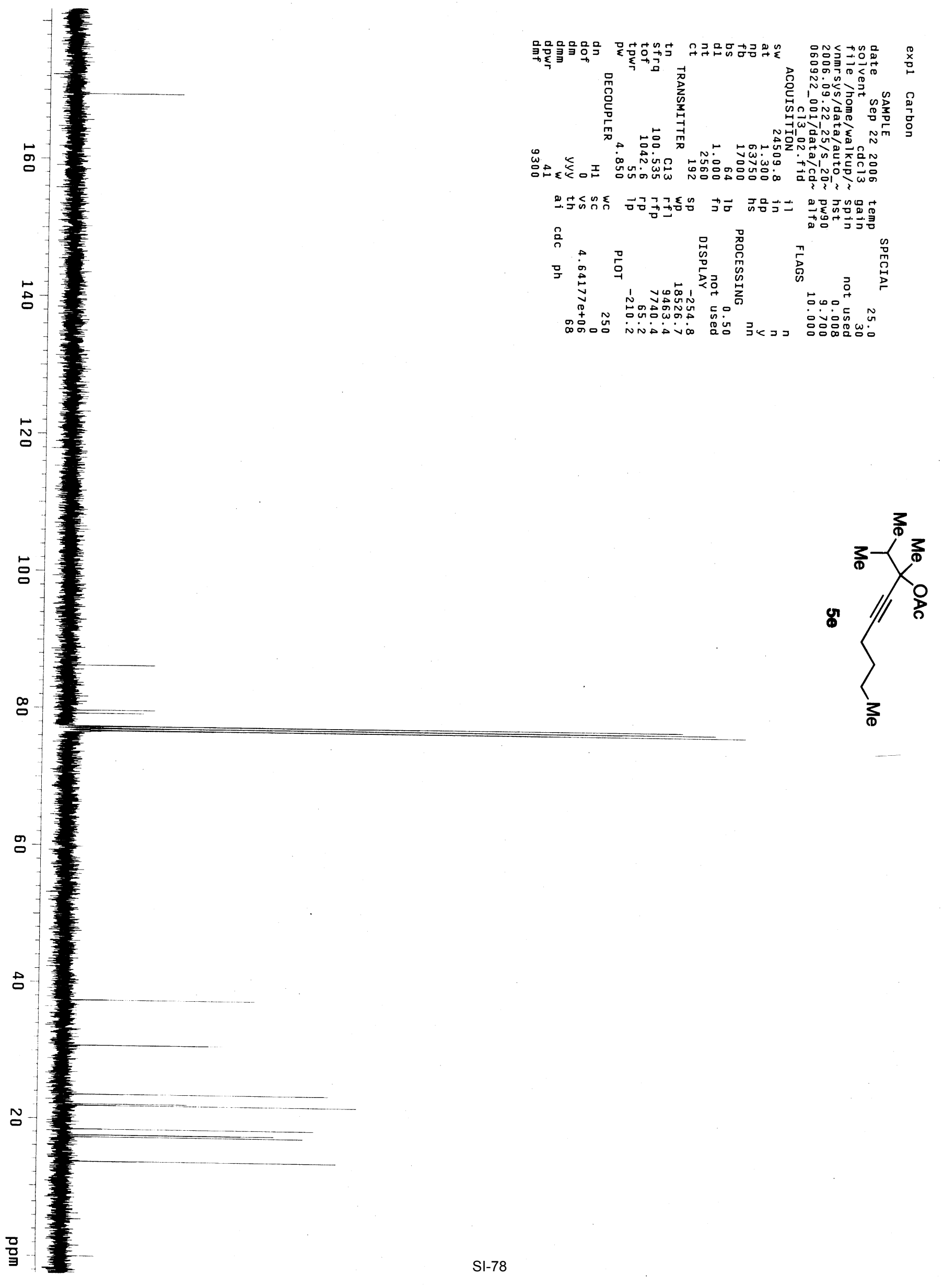




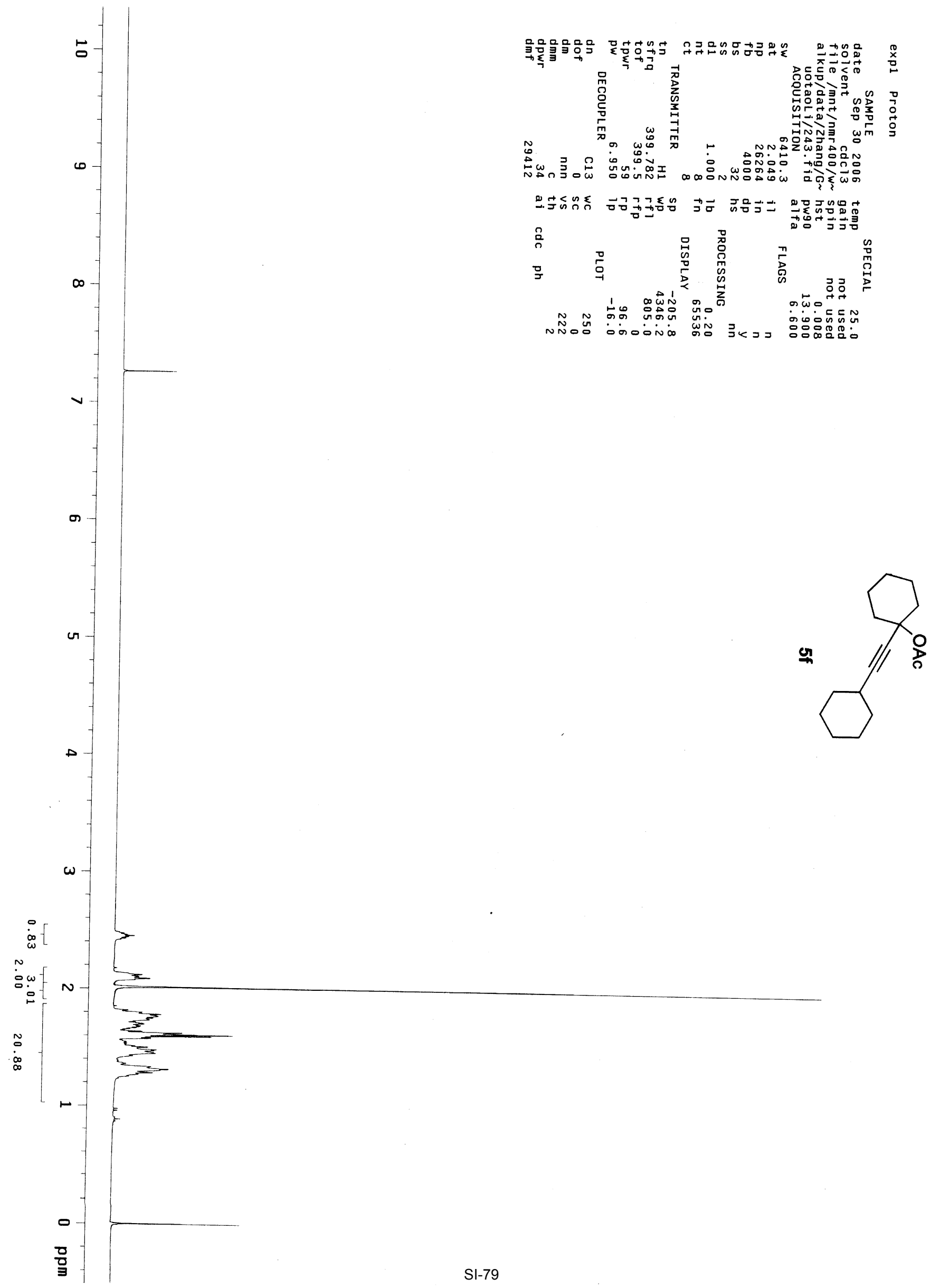




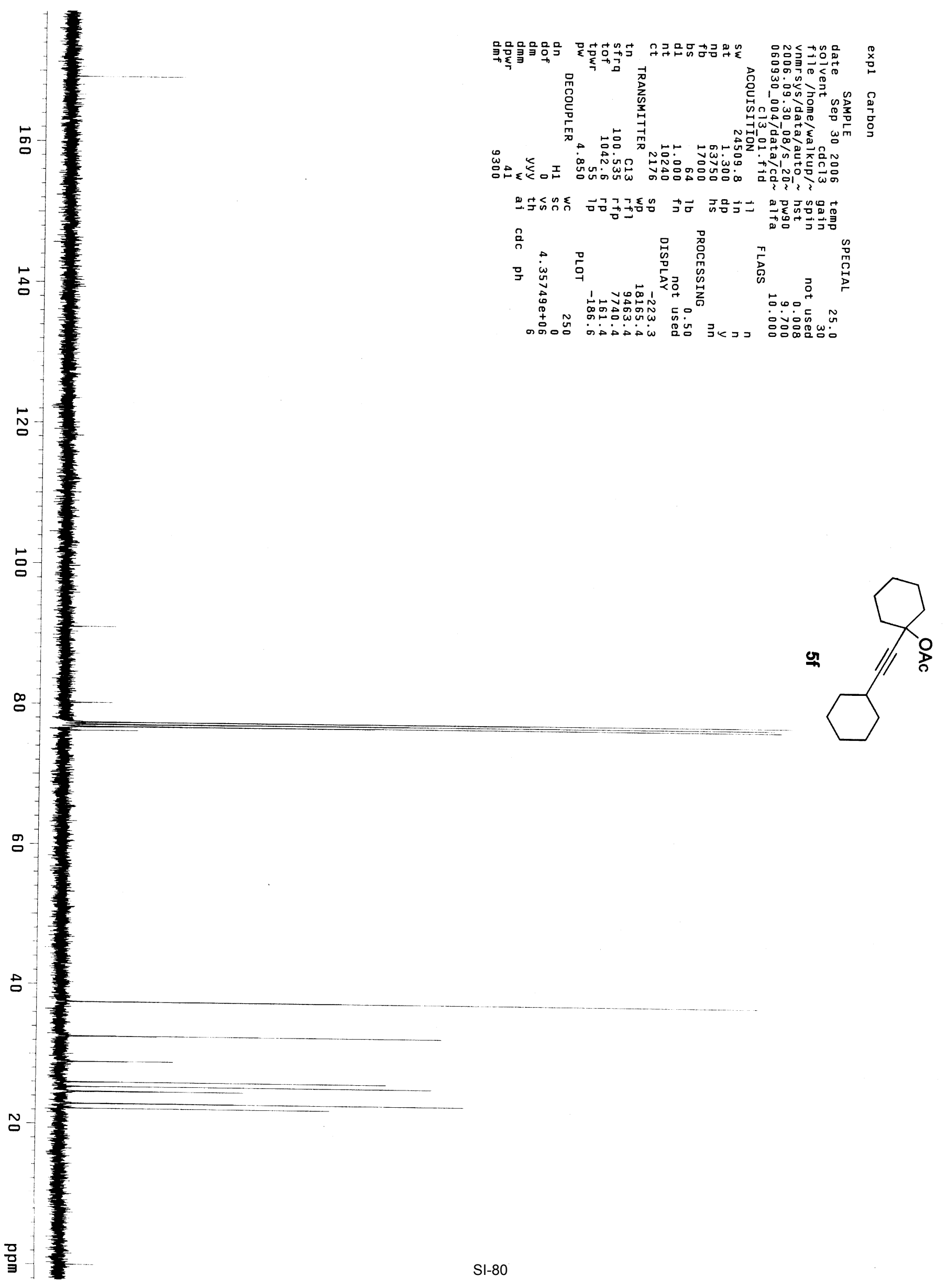



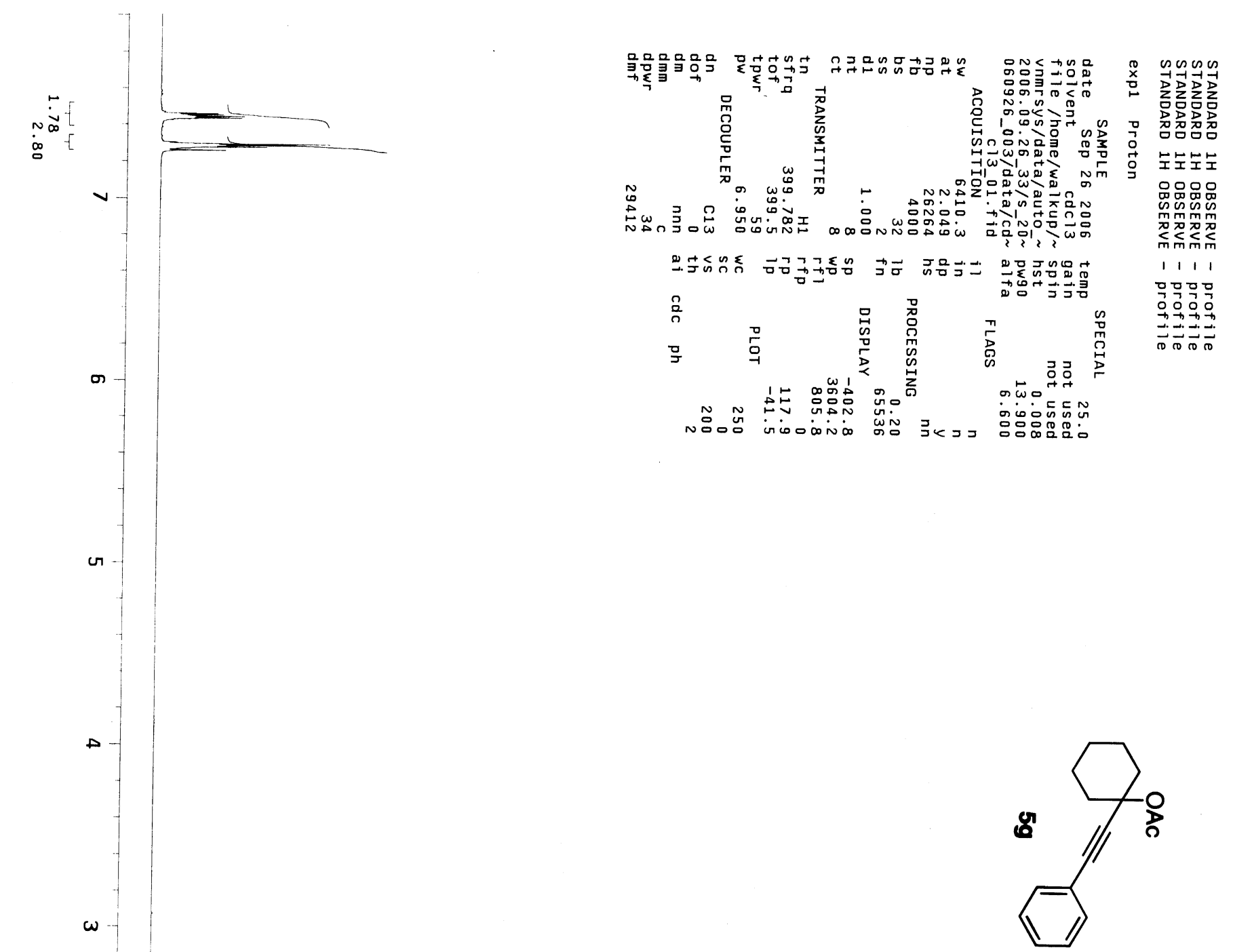

몸 

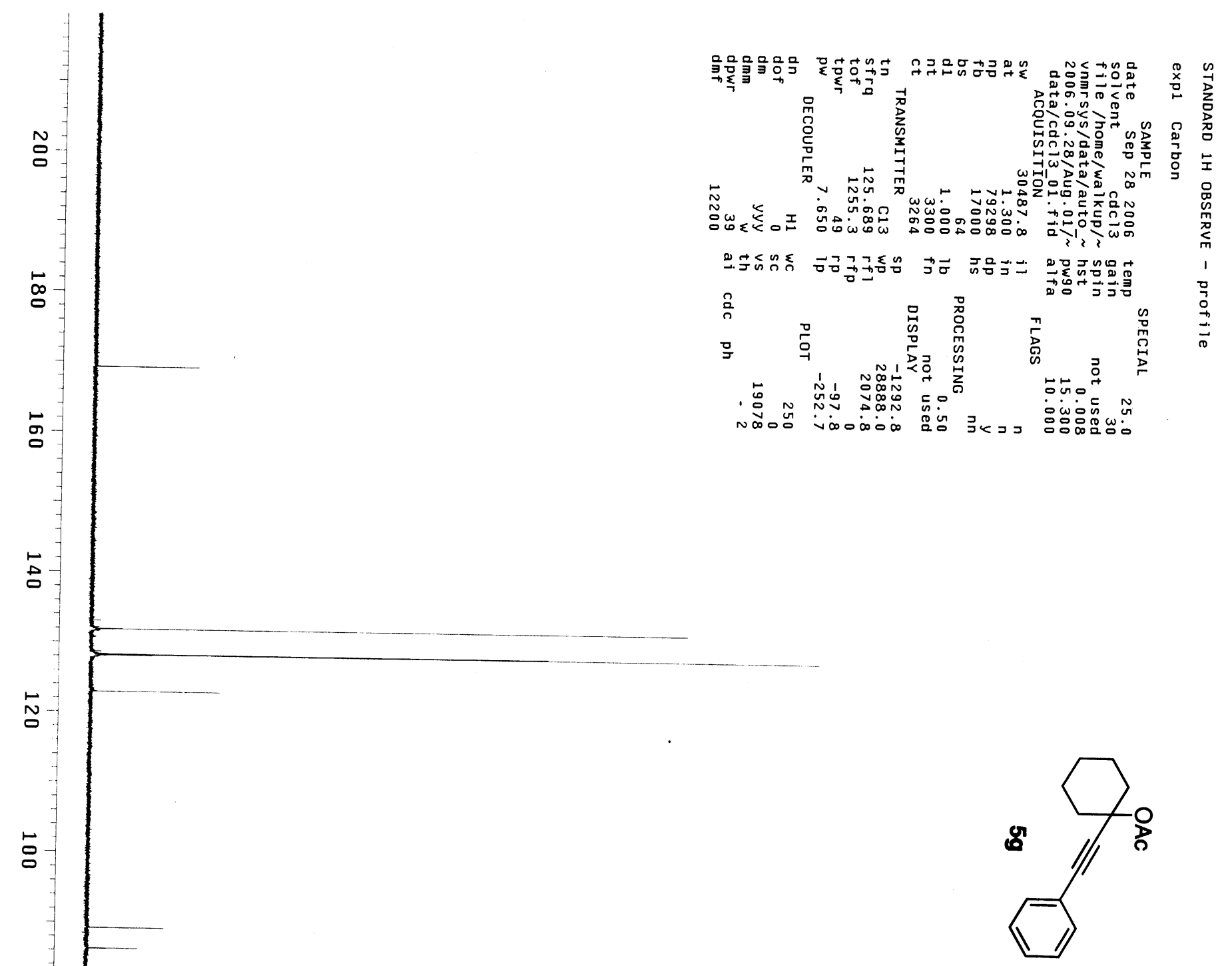

$\stackrel{\infty}{\circ}$

g

a

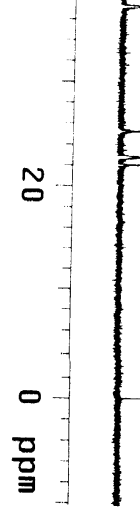

$\stackrel{5}{\circ}$

N

เ

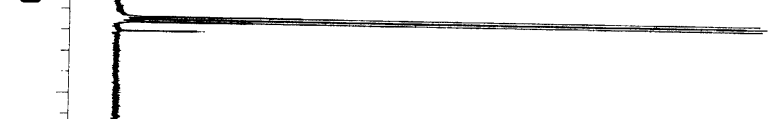

.

. 

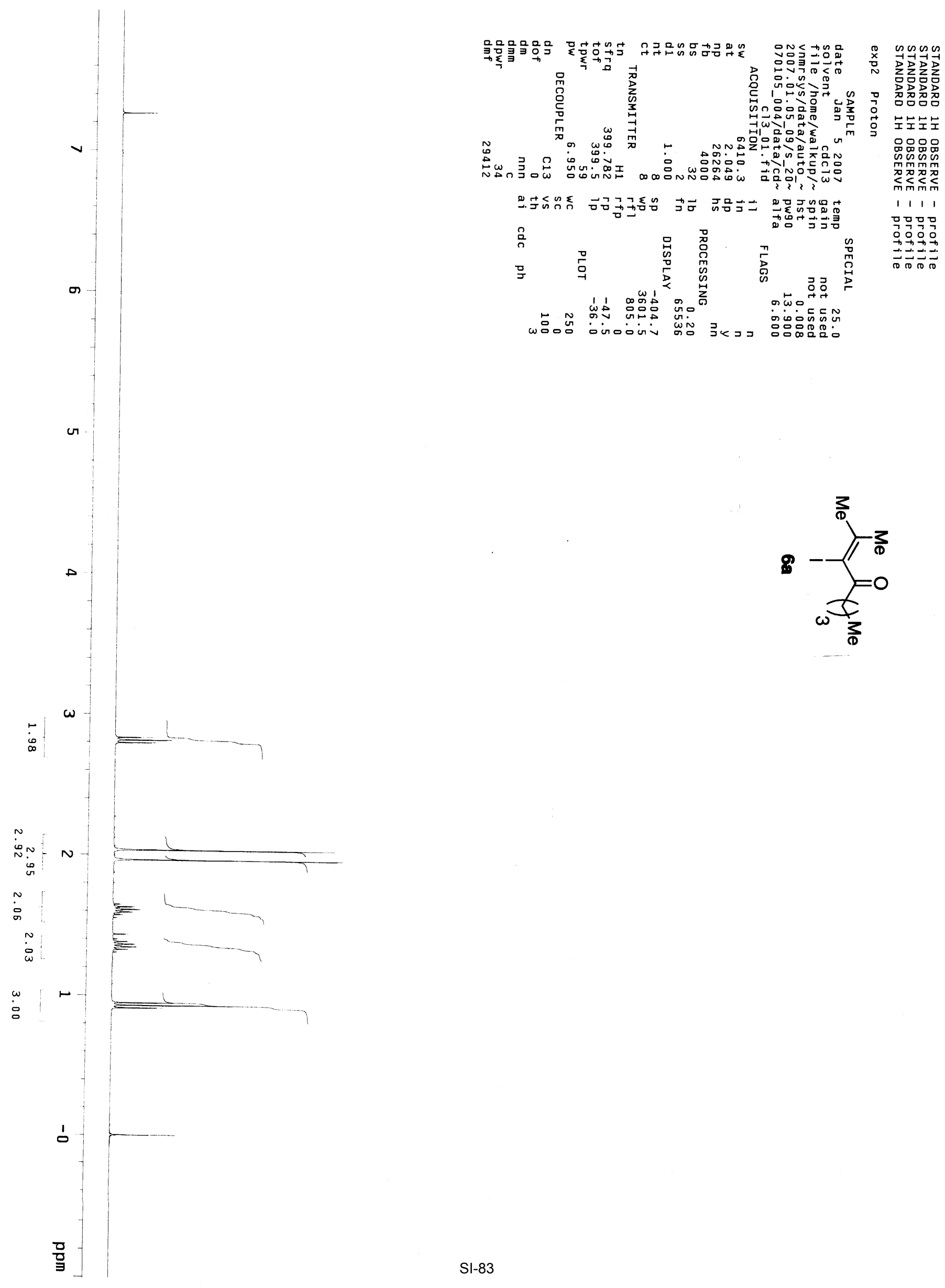

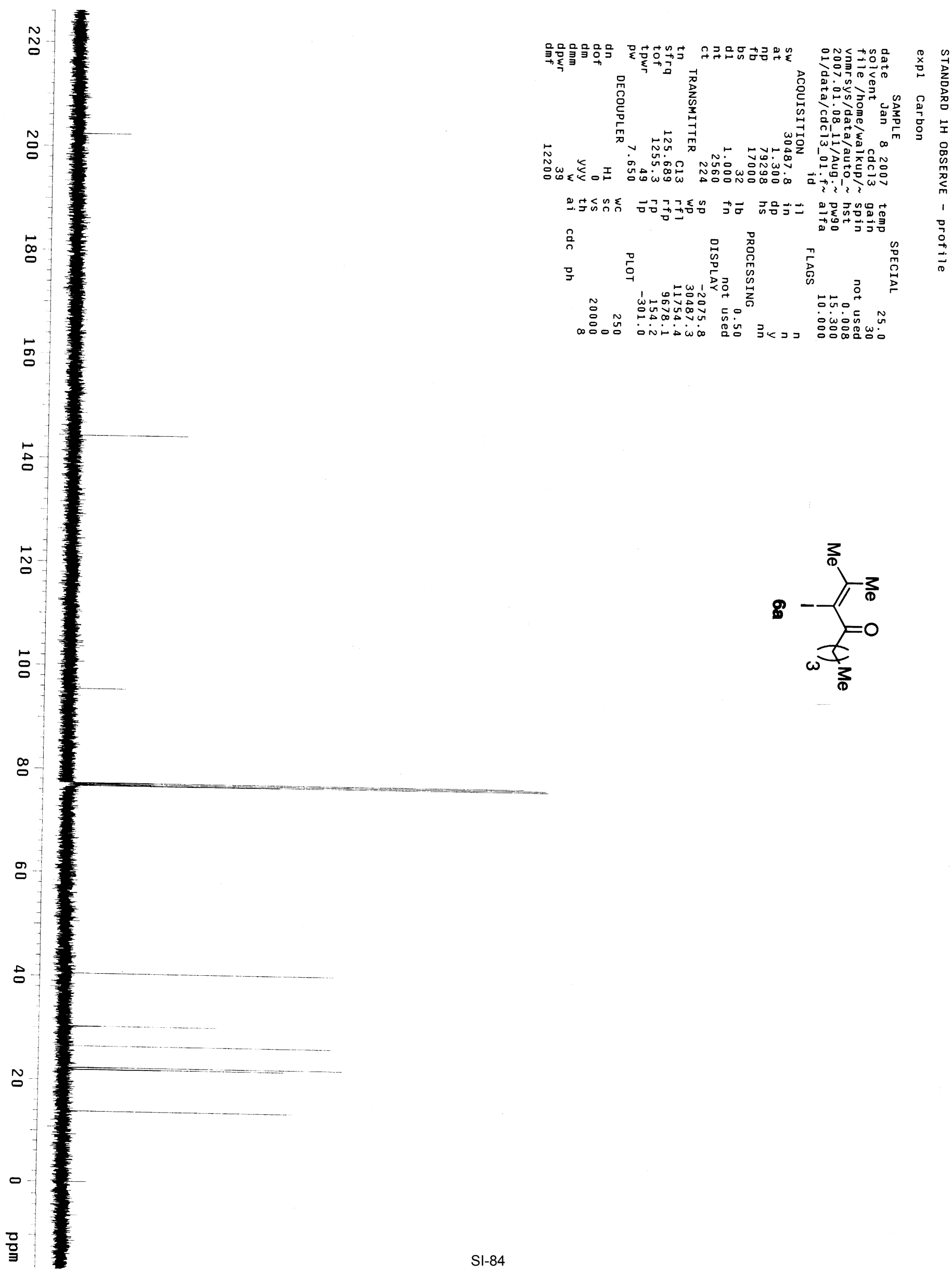

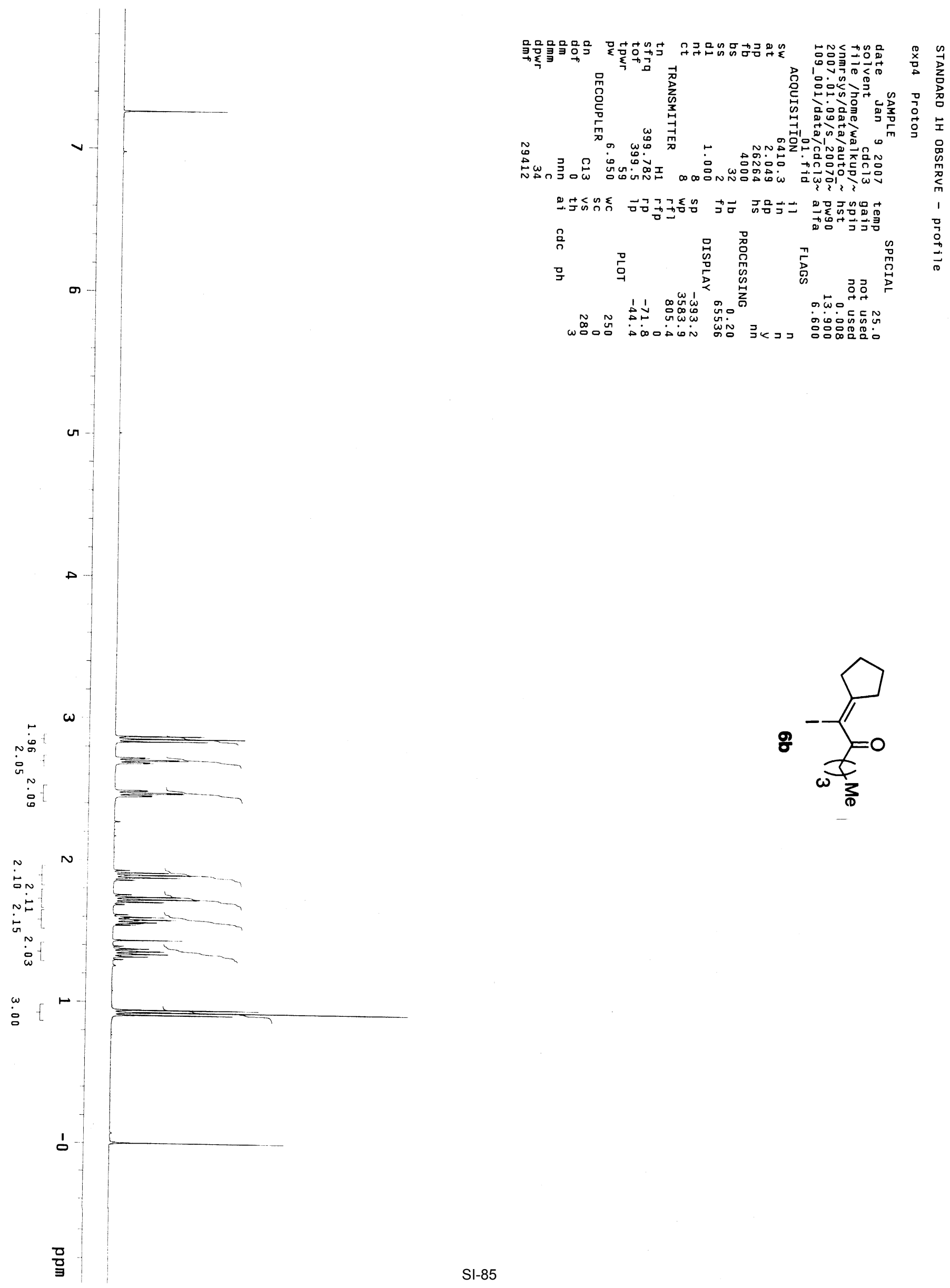


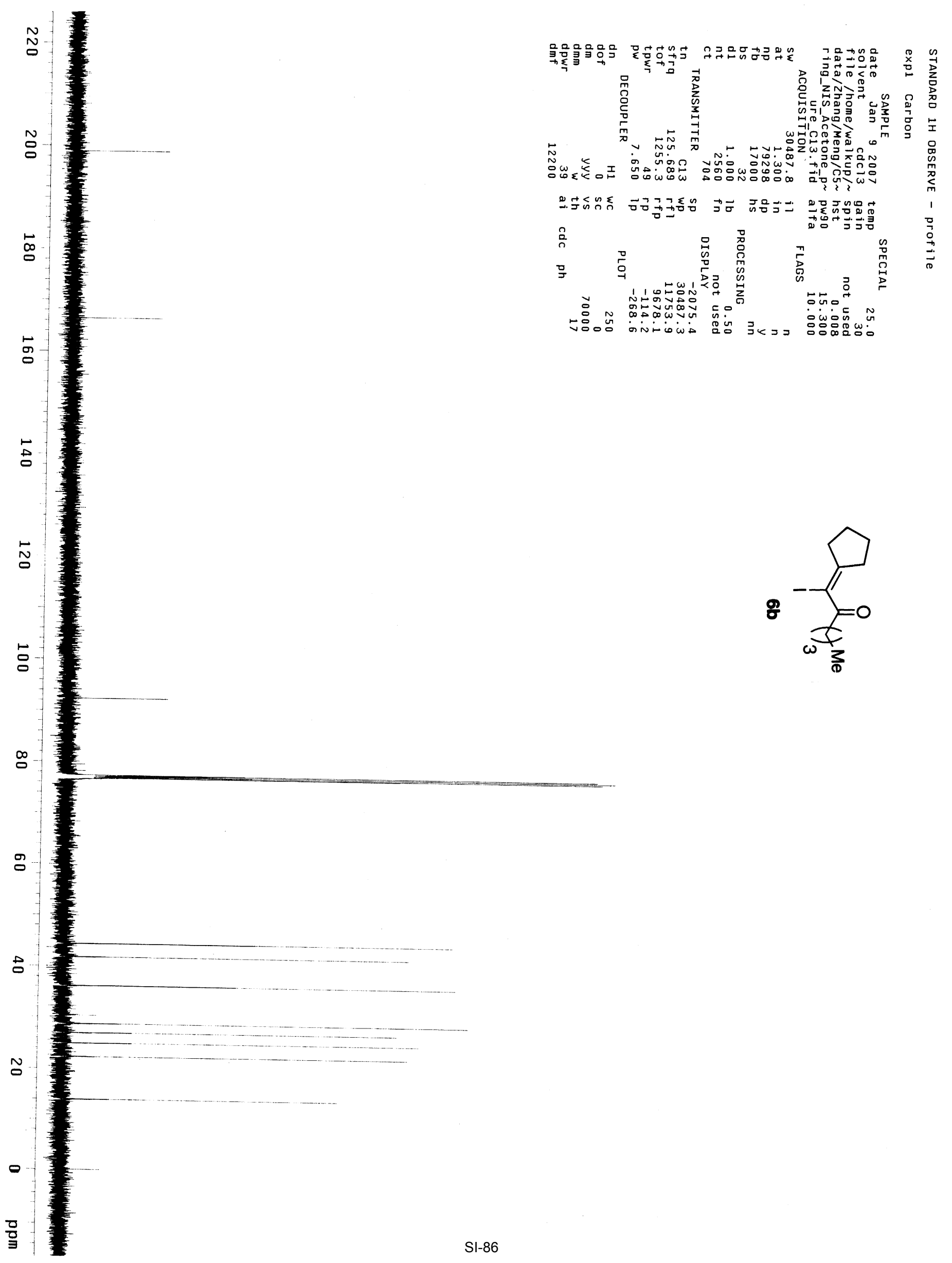




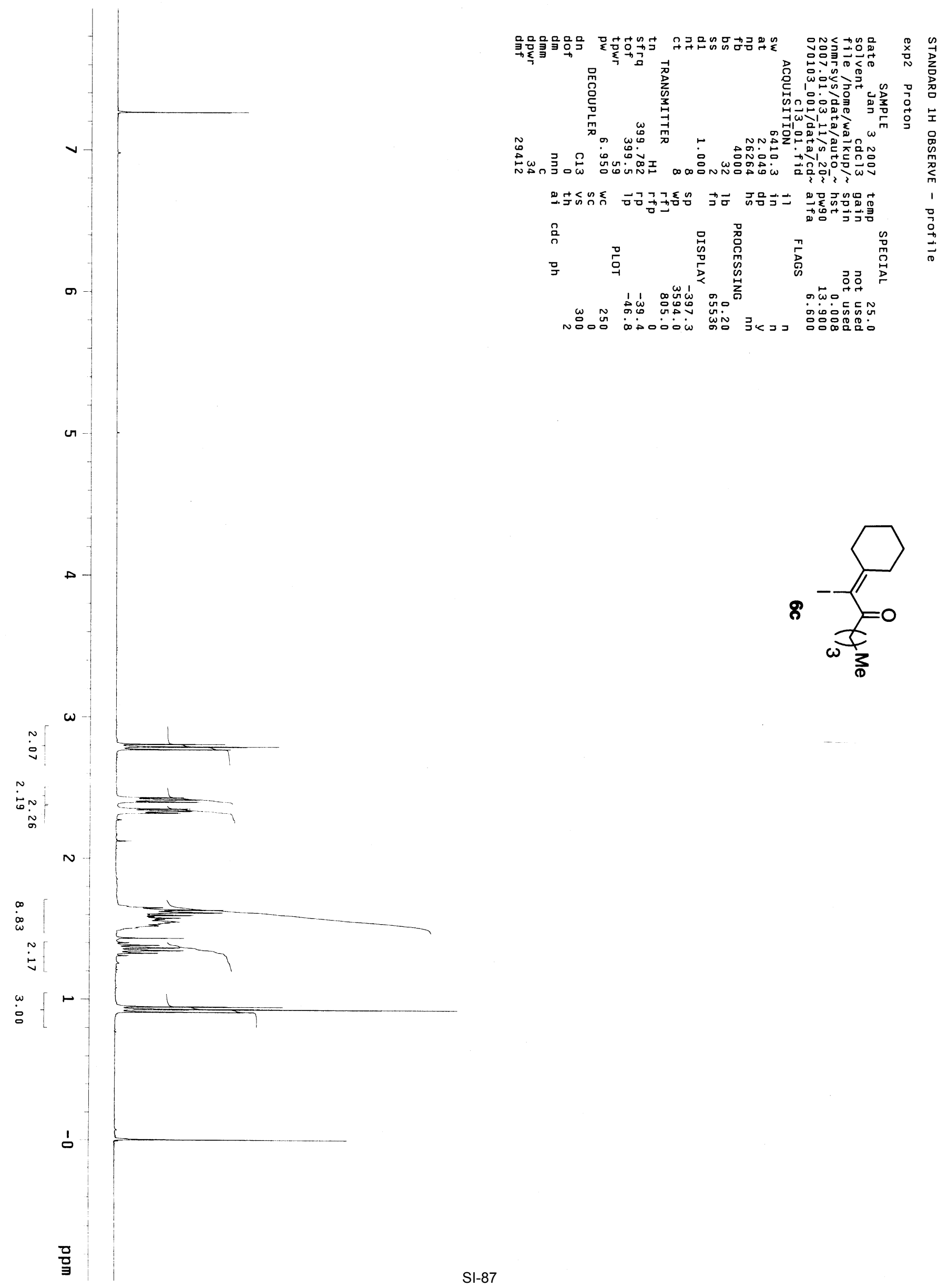



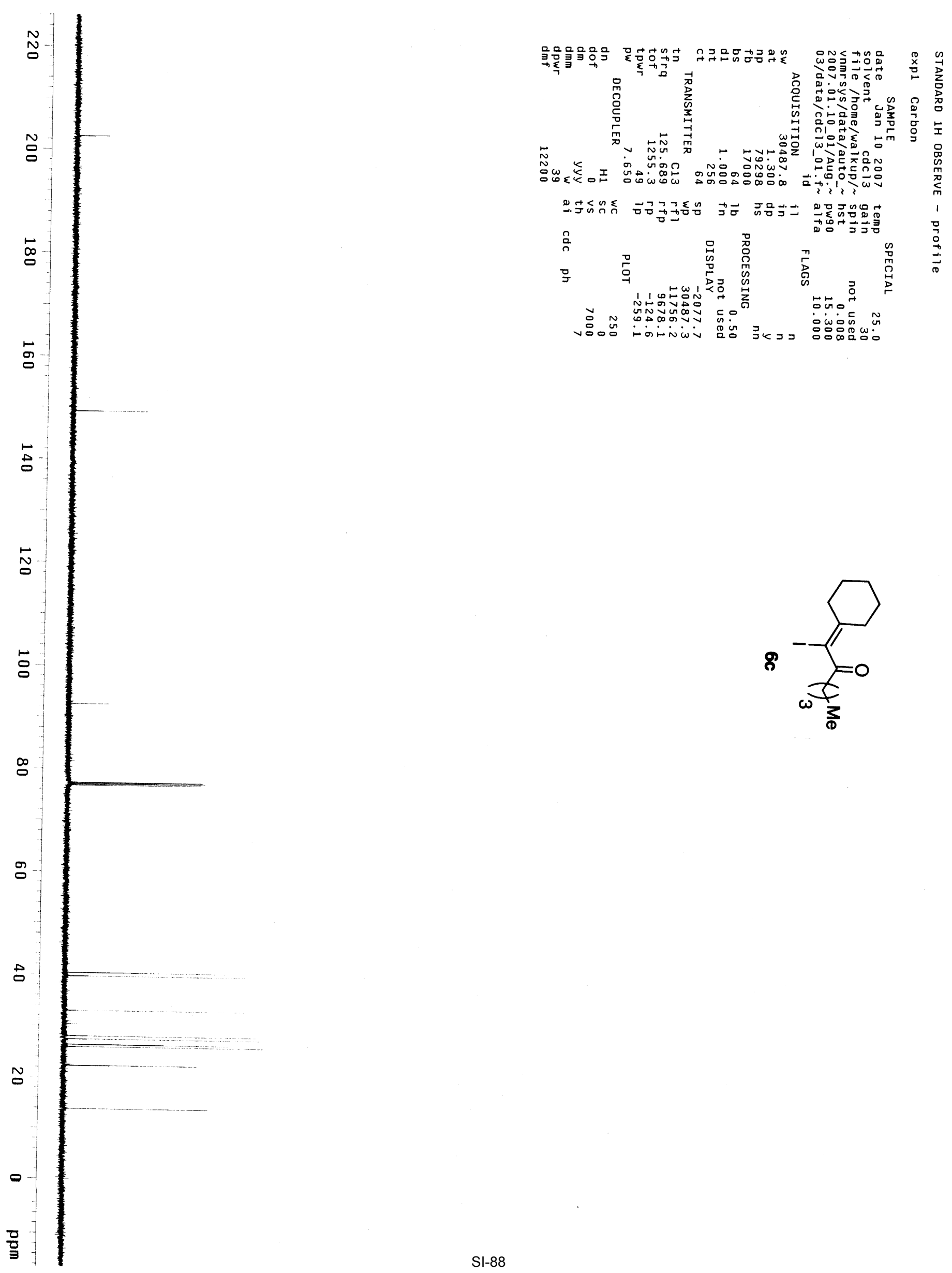


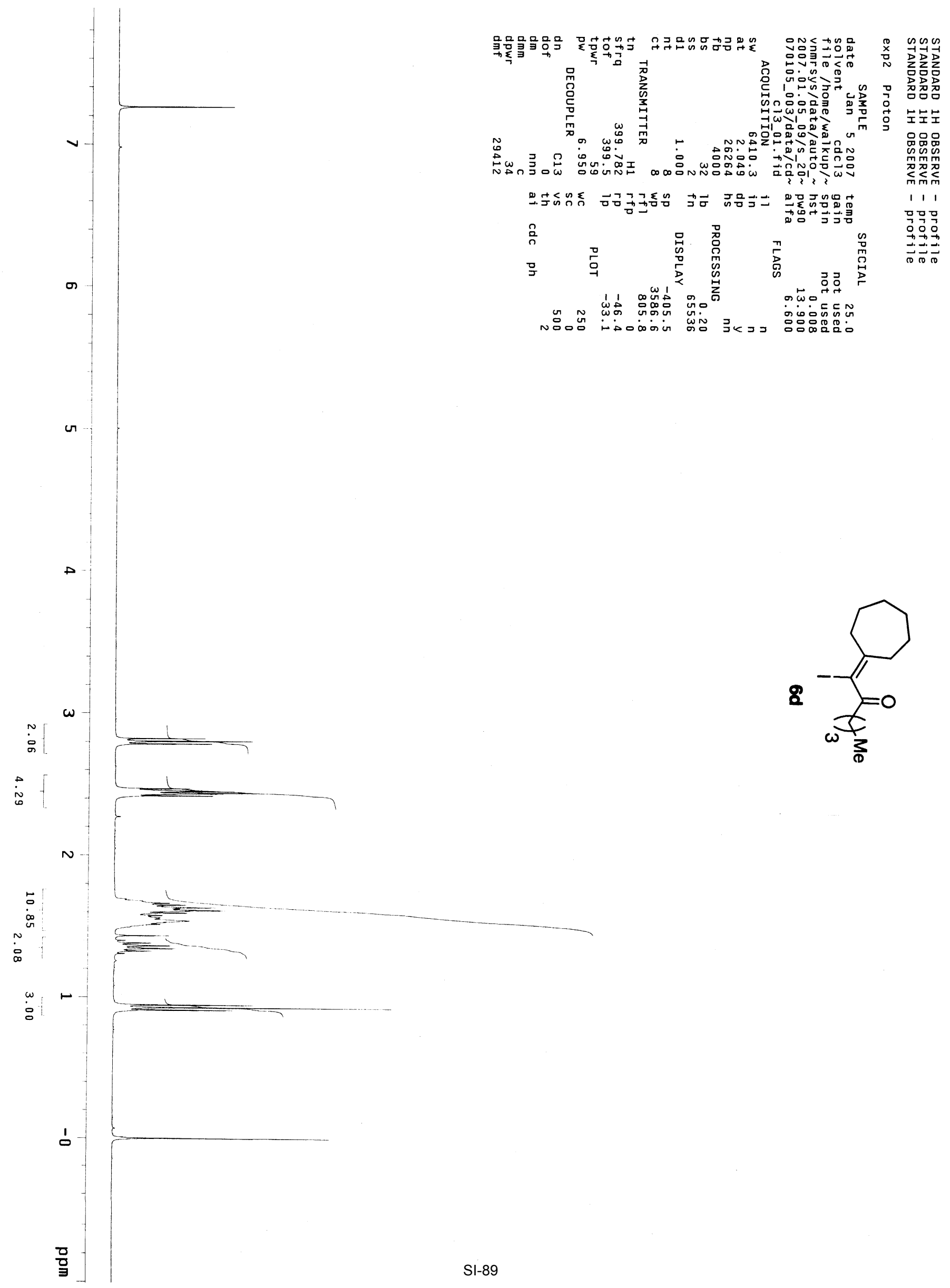



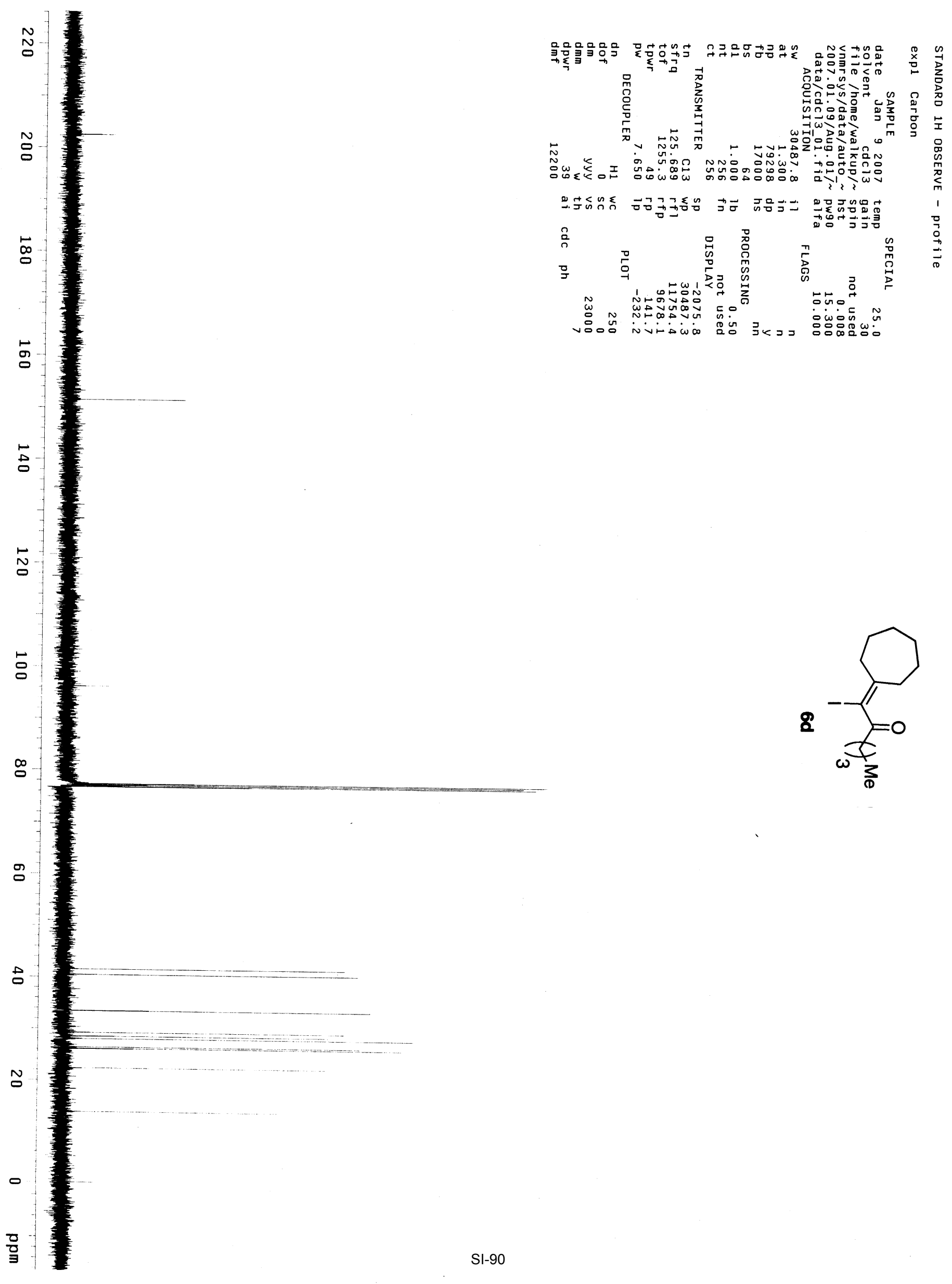

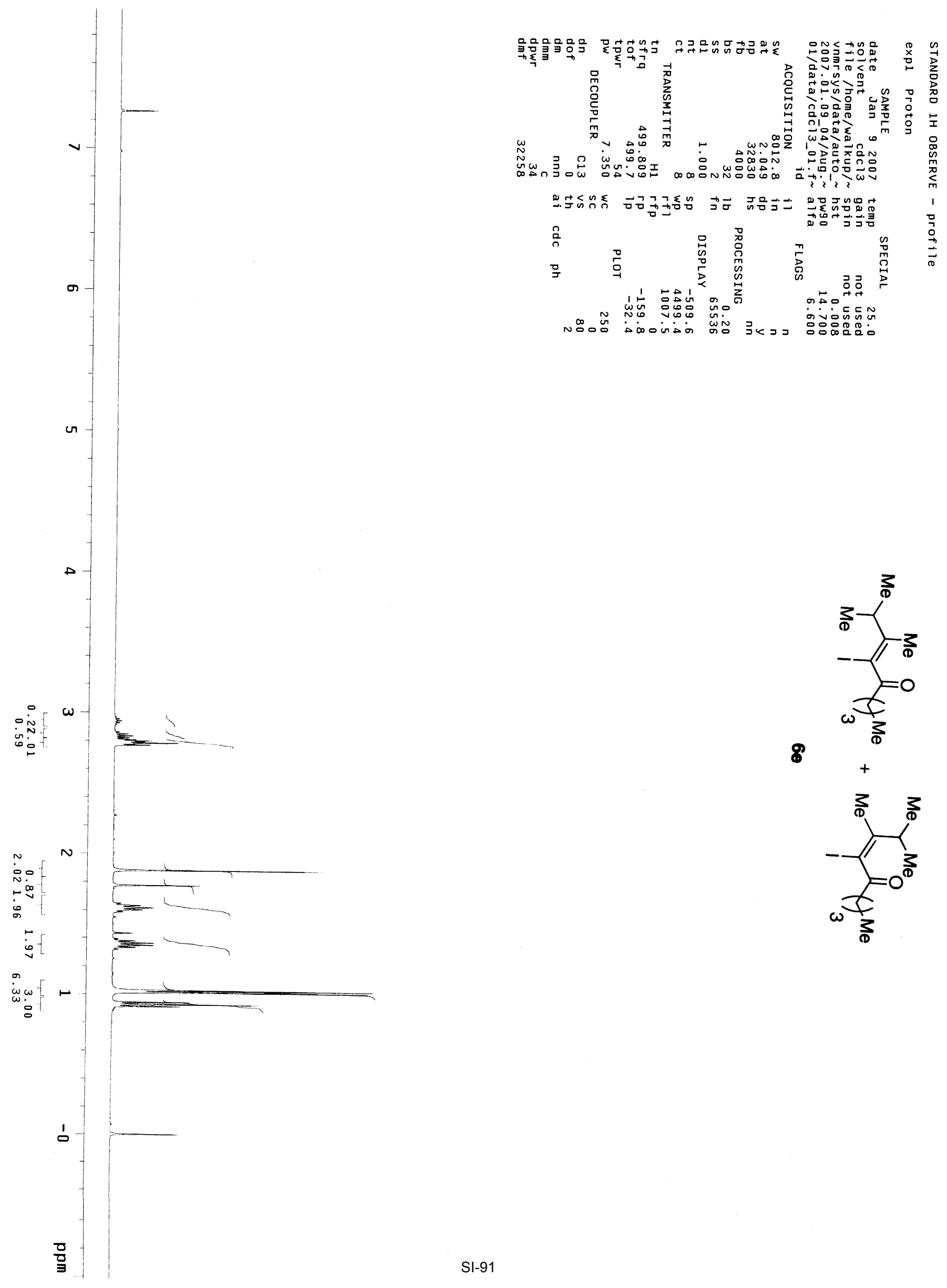


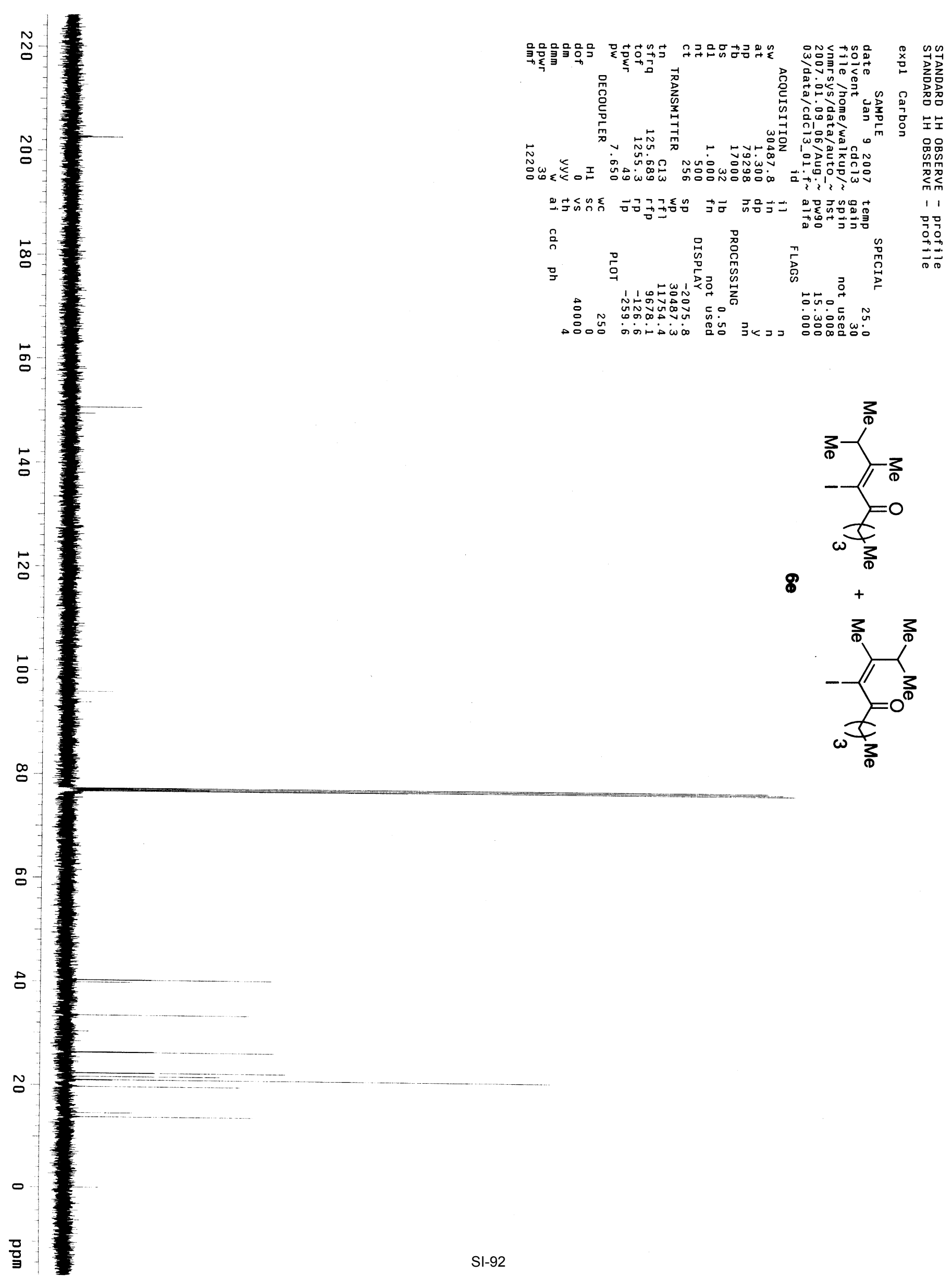



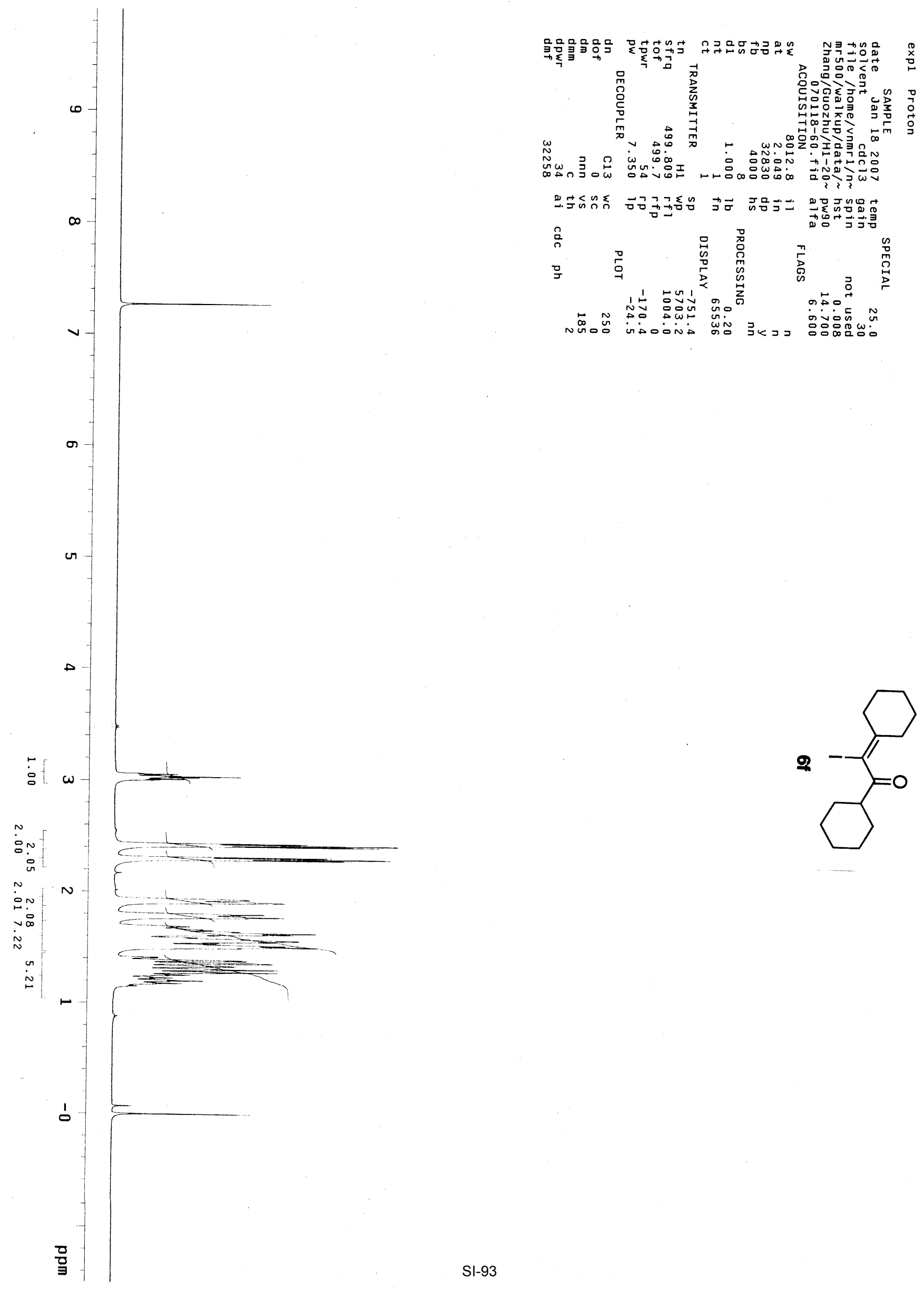


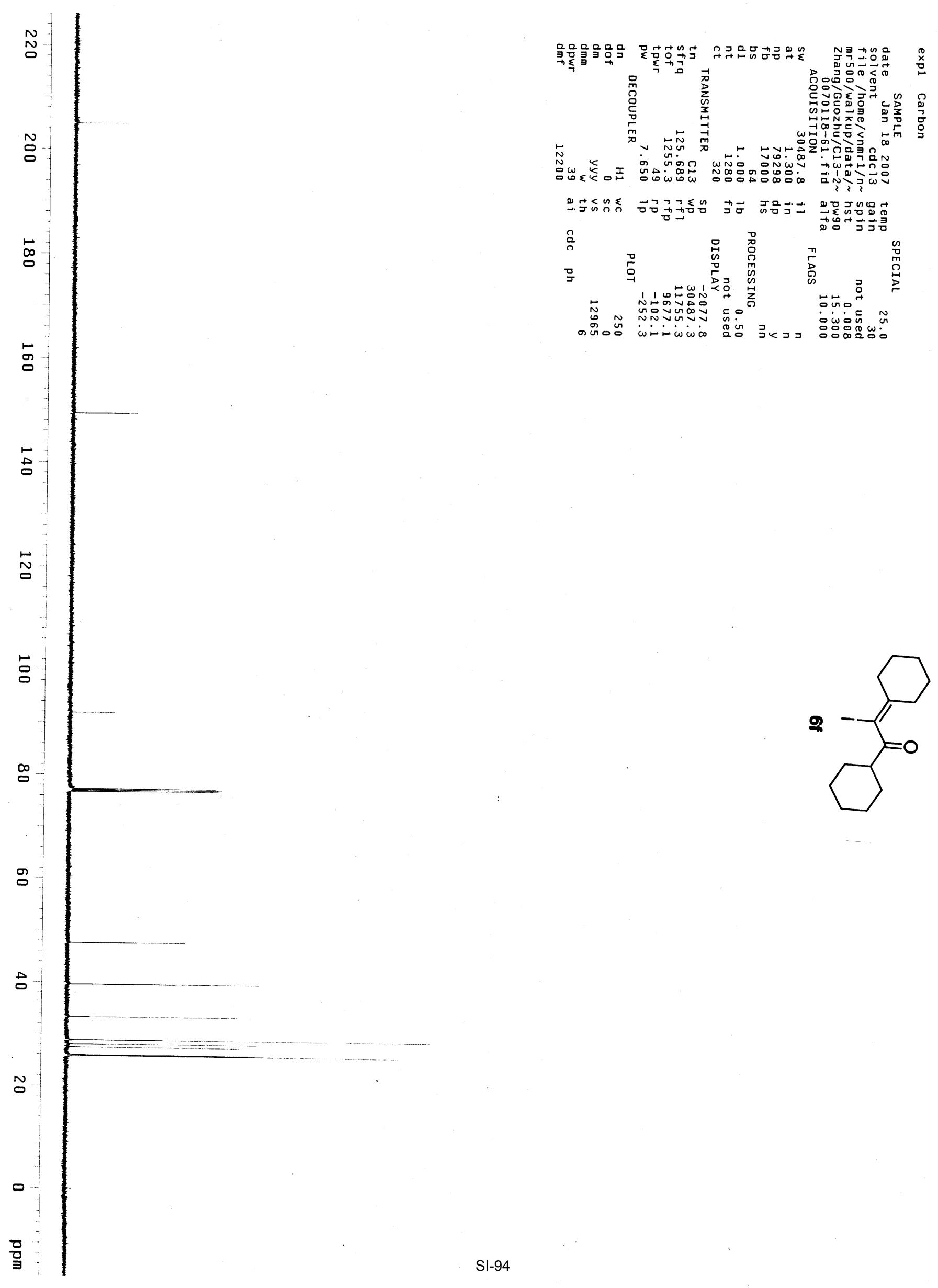



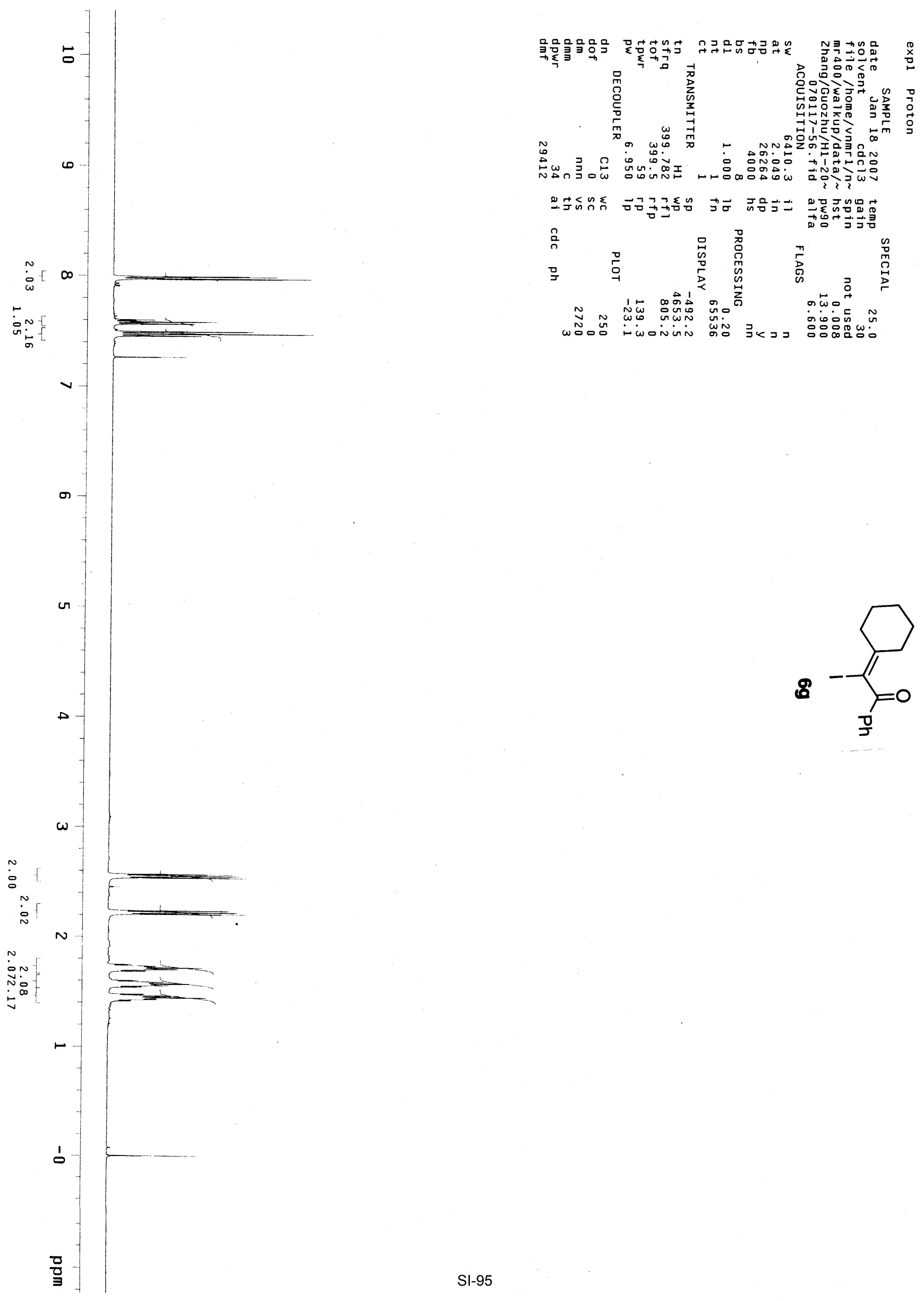


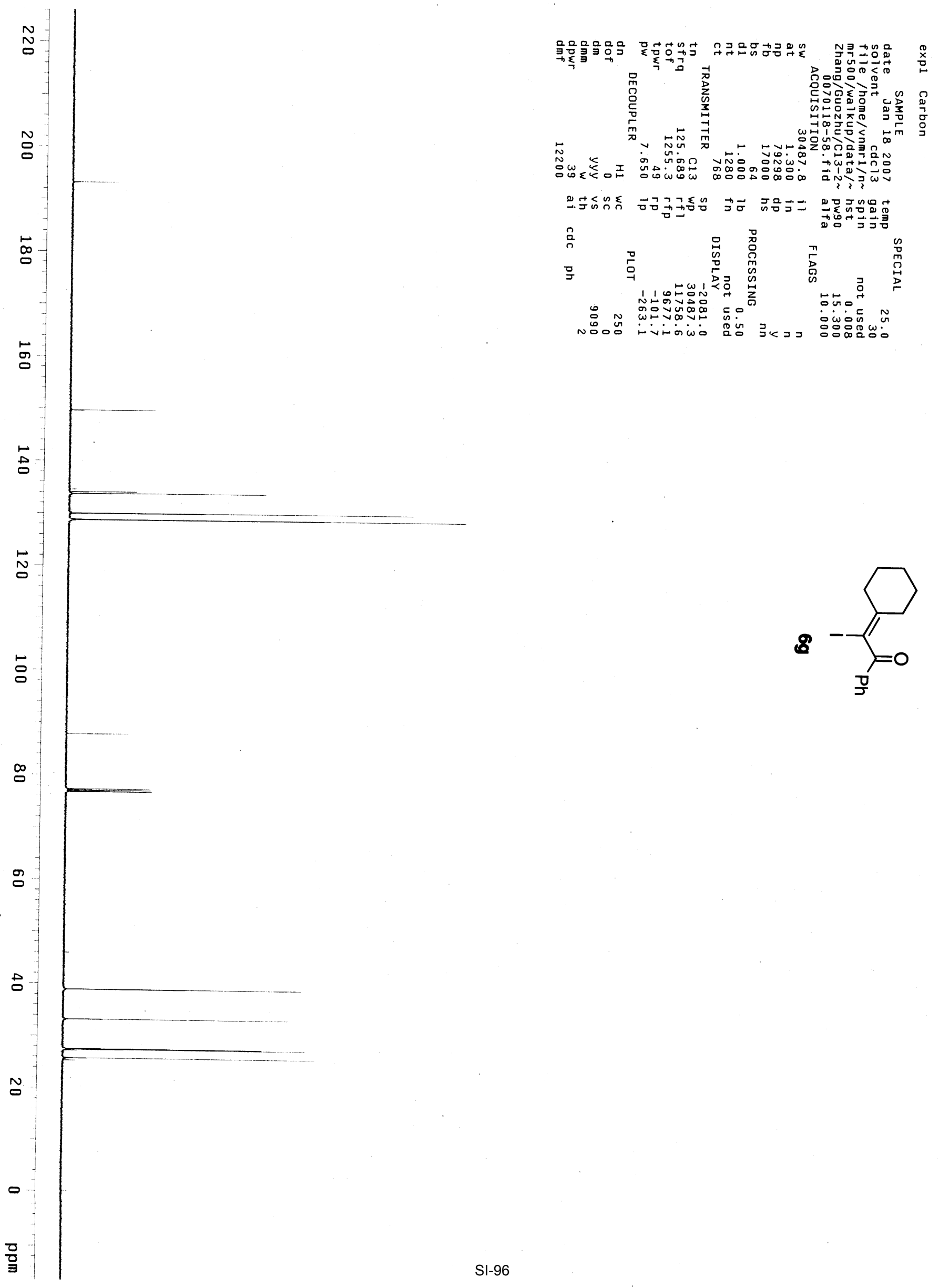

